ANALYSIS OF FLOOD-FLOW FREQUENCY, FLOW

DURATION, AND CHANNEL-FORMING FLOW FOR

THE JAMES RIVER IN SOUTH DAKOTA

By Rick D. Benson

U.S. GEOLOGICAL SURVEY

Water-Resources Investigations Report 87-4208

Prepared in cooperation with the

U.S. BUREAU OF RECLAMATION



Huron, South Dakota 1988 
DEPARTMENT OF THE INTERIOR

DONALD PAUL HODEL, Secretary

U.S. GEOLOGICAL SURVEY

Dallas L. Peck, Director

For additional information

write to:

District Chief

U.S. Geological Survey

Rm. 317, Federal Bldg.

2004 th St. SW

Huron, SD 57350
Copies of this report can be purchased from:

U.S. Geological Survey Books and Open-File Reports Federal Center, Bldg. 810 Box 25425

Denver, CO 80225-0425 




Introduction . . . . . . . . . . . . . . . . . . . . . . . 1

Background ............................ 1

Objectives .......................... 2

Physical setting .. . . . . . . . . . . . . . . . . 2

Analysis of flood frequency . . . . . . . . . . . . . . . . . 2

Main-stem locations .................... . 6

Tributary locations .. . . . . . . . . . . . . . 6

Gaged tributaries ................... 6

Ungaged tributaries ................... 13

Analysis of flow duration ...................... 13

James River at Columbia... . . . . . . . . . . . . 15

James River near Stratford . . . . . . . . . . . . . 15

James River at Ashton ................... 18

James River near Redfield.................. 18

James River at Huron . . . . . . . . . . . . . . . . . 18

James River near Forestburg . . . . . . . . . . . . . . . 22

James River near Scotland .................... 22

Summary of analysis of flow duration . . . . . . . . . . . . 25

Analysis of channel-forming flow . . . . . . . . . . . . . . . 25

Factors affecting channel formation . . . . . . . . . . . . . 25

Relation between bankfull-capacity, flood-frequency, and flow-

duration data................... . . . 26

Summary of analysis of channel-forming flow . . . . . . . . . 28

Conclusions . . . . . . . . . . . . . . . . . . . . . 29

Selected references . . . . . . . . . . . . . . . . . . . 31

Supplemental information . . . . . . . . . . . . . . . . . . . . 33

Frequency curves for instantaneous peak flow in the James

River at eight locations . . . . . . . . . . . . . . . 34

Frequency curves for maximum mean daily flow during June,

July, and August in the James River at eight locations . . . . . 43

Duration hydrograph tables for the James River at seven locations . . 52 


\section{ILLUSTRATIONS}

Page

Figure 1. Map showing James River basin in South Dakota. ....... 3 2-8. Duration hydrographs for daily discharges of the James River:

2. at Columbia, water years 1947-85. . . . . . . . 16

3. near Stratford, water years 1954-72 . . . . . . . 17

4. at Ashton, water years 1947-85. . . . . . . . . 19

5. near Redfield, water years 1957-85. . . . . . . . 20

6. at Huron, water years 1947-85 .......... 21

7. near Forestburg, water years 1957-85......... 23

8. near Scotland, water years 1937-85.......... 24

9-16. Frequency curves for instantaneous peak flow for the

James River:

9. at Columbia, S. Dak. .......... 35

10. near Stratford, S. Dak. ............ 36

11. at Ashton, S. Dak. ............ 37

12. near Redfield, S. Dak. ........... 38

13. at Huron, S. Dak. .............. 39

14. near Forestburg, S. Dak. ............ 40

15. near Mitchell, S. Dak. ............. 41

16. near Scotland, S. Dak. .............. 42

17-24. Frequency curves for maximum daily mean flow during June, July, and August for the James River:

17. at Columbia, S. Dak. . . . . . . . . . . 44

18. near Stratford, S. Dak. . . . . . . . . . 45

19. at Ashton, S. Dak. . . . . . . . . . . . 46

20. near Redfield, S. Dak. . . . . . . . . . 47

21. at Huron, S. Dak. . . . . . . . . . . . . 48

22. near Forestburg, S. Dak. ............ 49

23. near Mitchell, S. Dak. ............ 50

24. near Scotland, S. Dak. ........... 51 
Table 1. Drainage area, period of record, and discharges of continuous-record streamflow-gaging stations on

the James River main stem within South Dakota . . . . . . . . 4

2. Drainage area, period of record, and discharges of continuous-record streamflow-gaging stations within the James River basin within South Dakota . . . . . . 5

3. Magnitude and probability of instantaneous peak flow at streamflow-gaging stations on the James River in South Dakota subsequent to closure of Jamestown Reservoir in water year 1953 . . . . . . . . . . . . . . . . . . 7

4. Magnitude and probability of maximum daily mean flow during June, July, and August at streamflow-gaging stations on the James River in South Dakota subsequent to closure of Jamestown Reservoir in water year 1953 . . . . . . . . . . . . 8

5. Drainage area data for tributaries which discharge directly into the James River within South Dakota . . . . . . 9

6. Magnitude and probability of instantaneous peak flow at continuous-record streamflow-gaging stations on tributaries within the James River basin in South Dakota . . . . . . . 10

7. Magnitude and probability of maximum daily mean flow during June, July, and August at continuous-record streamflowgaging stations on tributaries within the James River basin in South Dakota ......................... 11

8. Estimated magnitude and probability of instantaneous peak flow at the confluence of gaged tributaries and the James River within South Dakota . . . . . . . . . . . . 12

9. Estimated magnitude and probability of instantaneous peak flow at the confluence of ungaged tributaries and the James River in South Dakota . . . . . . . . . . . . 14

10-16. Discharge data for duration hydrograph for the James River:

10. at Columbia, S. Dak. (station 06471000), for 39-year period October 1946 to September 1985 . . . . . . . . 53

11. near Stratford, S. Dak. (station 06472000), for 19-year period October 1953 to September 1972. . . . . 65

12. at Ashton, S. Dak. (station 06473000), for 39-year period October 1946 to September 1985. . . . . . . . . 77

13. near Redfield, S. Dak. (station 06475000), for 29-year period October 1956 to September 1985 . . . . 89

14. at Huron, S. Dak. (station 06476000), for 39-year period October 1946 to September 1985 ... . . . . . . 101

15. near Forestburg, S. Dak. (station 06477000), for 29-year period October 1956 to September 1985 . . . . 113

16. near Scotland, S. Dak. (station 06478500), for 49-year period October 1936 to September 1985 . . . . 125

17. Recurrence interval of instantaneous peak flow equal to minimum bankfull capacity and days for which minimum bankfull capacity is equaled or exceeded for streamflowgaging stations on the James River in South Dakota 


\section{SELECTED FACTORS FOR CONVERTING INCH-POUND UNITS}

TO METRIC (INTERNATIONAL SYSTEM) UNITS

For those readers who may prefer to use metric (International System) units rather than inch-pound units, the conversion factors for the terms used in this report are given below.

Multiply inch-pound unit

\section{inch}

mile (mi)

square mile $\left(\mathrm{mi}^{2}\right)$

cubic foot per second $\left(\mathrm{ft}^{3} / \mathrm{s}\right)$

acre-foot (acre-ft)
By

25.40

1.609

2.590

0.028317

1,233
To obtain SI unit

millimeter

kilometer

square kilometer

cubic meter per second

cubic meter 


\title{
ANALYSIS OF FLOOD-FLOW FREQUENCY, FLOW DURATION, AND CHANNEL-FORMING FLOW FOR THE JAMES RIVER IN SOUTH DAKOTA
}

\author{
By Rick D. Benson
}

\begin{abstract}
The James River, which originates in North Dakota and joins the Missouri River near Yankton, South Dakota, is about 747 miles Iong, with about 474 river miles located in South Dakota. The James River basin includes 21,116 square miles, with 14,428 square miles located in South Dakota.

Bankfull capacity of the James River in South Dakota ranges from a minimum of about 200 cubic feet per second in the northern portion to a maximum of about 10,000 cubic feet per second near the mouth. Discharges that produce bankfull conditions on much of the river in South Dakota occur on an average of once in about 2 years. The 10-year flood flows, which range from 1,620 cubic feet per second (at the gage near stratford) to 8,870 cubic feet per second (at the gage near Scotland), cause major flooding on most of the river in South Dakota.

The river also has potential for extended periods of low or zero flow, especially in the northern portion within South Dakota. Generally, low flows occur from late summer until spring snowmelt. The James River at Columbia had zero flow for 623 consecutive days from July 13, 1958, through March 26, 1960.

The channel pattern (channel alignment) has changed little since 1922 . This channel stability indicates that channel formation is approaching a state of equilibrium. It does not appear that velocities in the river are sufficient to carry the sediment being delivered by the tributaries.
\end{abstract}

\section{INTRODUCTION}

\section{Background}

In 1984, a Federally appointed Garrison Diversion Unit Study Commission recommended major changes in the Garrison Diversion Unit (GDU) in North Dakota (Garrison Diversion Unit Commission, 1984). On May 12, 1986, the Garrison Diversion Unit Reformulation Act of 1986 was signed into law. There are eight specific study areas identified within the Reformulation Act (H.R. 1116), seven of which are directly associated with impacts to the James River. The Reformulation Act directs the Secretary of Interior to submit a comprehensive report to the Congress as soon as practicable but not later than the end of fiscal year 1988 (Amended Section 5(C)(1) Public Law 89-108). 
The U.S. Bureau of Reclamation is the lead agency for evaluating the potential effects of GDU on the James River in South Dakota. As part of this evaluation, the Bureau requested that the U.S. Ceological Survey conduct the flood-frequency, flow-duration, and channel-forming-flow studies that are summarized in this report.

\section{Objectives}

The objectives of this study were to analyze flood-flow frequency, flow duration, and channel-forming flow for the James River in South Dakota. Flood-flow frequency analyses also were made for certain tributaries within the James River basin. The study effort was limited to the analysis of existing discharge records.

The drainage area for the entire basin within South Dakota was determined. A separate drainage-area map report was prepared (Benson and others, 1987).

\section{Physical Setting}

The James River, which originates in North Dakota and joins the Missouri River near Yankton, S. Dak., is about $747 \mathrm{mi}$ long, with about 474 river miles located in South Dakota ( $f i g .1$ ). The total area of the James River basin is $21,116 \mathrm{mi}^{2}$, with 14,428 $\mathrm{mi}^{2}$ located with in South Dakota. Additional information concerning the river setting and hydrology can be found in a previous study by Benson (1983).

The gaging stations for which discharge records were analyzed as a part of this study are identified on figure 1. Data for continuous-record gaging stations operated by the U.S. Geological Survey within the James River basin in South Dakota are included in table 1 (main-stem stations) and in table 2 (tributary stations).

\section{ANALYSIS OF FLOOD FREQUENCY}

Statistical flood-flow frequency analyses were made for the main-stem gaging stations and for gaged tributaries that have 10 or more years of continuous record. The analyses were made by using the log-Pearson Type III frequency distribution based on procedures recommended by the U.S. Water Resources Council (1981).

The frequency analyses were made on two sets of flow data for the mainstem locations and for the tributary gages. The first frequency analyses were made for the instantaneous peak flow data stored in the Water Data Storage and Retrieval System (WATSTORE) Peak Flow File for each gaging station. The second frequency analyses were made for data sets containing the maximum daily mean discharge which occurred at each gaging station during the months of June, July, and August of each year (that is, a summer discharge). The analyses were made on the maximum daily mean discharge because instantaneous peak flow data are not generally available for the months of June, July, and August. Inspection of flow data on the James River indicates that the maximum daily mean discharge generally is within 5 percent of the instantaneous peak flow occurring on that same day. 




Figure 1.--James River basin in South Dakota. 





Table 2.--Drainage area, period of record, and discharges of continuous-record streamflow-gaging stations within the James River basin in South Dakota

\begin{tabular}{|c|c|c|c|c|c|c|c|c|}
\hline \multirow[b]{3}{*}{$\begin{array}{l}\text { Station } \\
\text { number }\end{array}$} & \multirow[b]{3}{*}{ Station name } & \multirow{3}{*}{$\begin{array}{l}\text { Distance } \\
\text { upstream } \\
\text { from mouth } \\
\text { (river miles) }\end{array}$} & \multirow{2}{*}{\multicolumn{2}{|c|}{$\begin{array}{l}\text { Drainage area } \\
\text { (square miles) }\end{array}$}} & \multicolumn{4}{|c|}{ Discharge records } \\
\hline & & & & & \multirow[b]{2}{*}{$\begin{array}{l}\text { Period } \\
\text { of } \\
\text { record }\end{array}$} & \multicolumn{3}{|c|}{ Discharge (cublc feet per second) } \\
\hline & & & Total & $\begin{array}{l}\text { Non- } \\
\text { contrib- } \\
\text { uting }\end{array}$ & & $\begin{array}{l}\text { Minimum } \\
\text { daily }\end{array}$ & Average & $\begin{array}{c}\text { Maximum } \\
\text { instantaneous }\end{array}$ \\
\hline 06471200 & $\begin{array}{l}\text { Maple River at North } \\
\text { Dakota-South Dakota } \\
\text { State line }\end{array}$ & 15.7 & 716 & 332 & $6 / 56-9 / 85$ & 0 & 19.8 & 5,930 \\
\hline 06471500 & $\begin{array}{l}\text { Elm River at } \\
\text { Westport, S. Dak. }\end{array}$ & 30.4 & 1,493 & 444 & $10 / 45-9 / 85$ & 0 & 45.7 & 12,600 \\
\hline 06471898 & $\begin{array}{c}\text { Moccas In Creek near } \\
\text { Warner, S. Dak. }\end{array}$ & $21 \cdot 5$ & 304 & 0 & $10 / 76-9 / 80$ & 0 & 2 & 387 \\
\hline 06472500 & $\begin{array}{l}\text { Mud Creek near } \\
\text { Stratford, S. Dak. }\end{array}$ & 14.7 & 738 & 64.2 & $\begin{array}{r}9 / 55-9 / 69 \\
10 / 76-9 / 77\end{array}$ & 0 & 9.34 & 1,180 \\
\hline 06473500 & $\begin{array}{c}\text { South Fork Snake Creek } \\
\text { near Athol, S. Dak. }\end{array}$ & 1 & 1,743 & 48.4 & $3 / 50-9 / 72$ & 0 & 11.2 & 6,810 \\
\hline 06473700 & $\begin{array}{l}\text { Snake Creek near } \\
\text { Ashton, S. Dak. }\end{array}$ & $21 \cdot 5$ & 2,657 & 48.4 & $\begin{array}{l}10 / 55-9 / 69 \\
10 / 76-9 / 79 \\
10 / 84-9 / 85\end{array}$ & , & 23.1 & 6,980 \\
\hline 06473750 & $\begin{array}{l}\text { Wolf Creek near } \\
\text { Ree Helghts, S. Dak. }\end{array}$ & 1 & 334 & 0 & $\begin{array}{r}9 / 59-9 / 81 \\
10 / 84-9 / 85\end{array}$ & 0 & 3.73 & 990 \\
\hline 06474000 & $\begin{array}{l}\text { Turtle Creek near } \\
\text { Tulare, S. Dak. }\end{array}$ & 33.7 & 1,124 & 0 & $\begin{array}{r}8 / 53-9 / 56 \\
9 / 65-9 / 81 \\
10 / 84-9 / 85\end{array}$ & , & 13.2 & 6,000 \\
\hline 06474300 & $\begin{array}{l}\text { Medicine Creek near } \\
\text { Zell, S. Dak. }\end{array}$ & 1 & 202 & 0 & $\begin{array}{r}9 / 59-9 / 81 \\
10 / 84-9 / 85\end{array}$ & 0 & 5.67 & 2,210 \\
\hline 06474500 & $\begin{array}{l}\text { Turtle Creek at } \\
\text { Redfleld, S. Dak. }\end{array}$ & 6.8 & 1,481 & 0 & $10 / 45-9 / 72$ & 0 & 24.8 & 7,660 \\
\hline 06475500 & $\begin{array}{l}\text { Dry Run near } \\
\text { Frankfort, S. Dak. }\end{array}$ & 8.1 & 201 & 0 & $9 / 55-9 / 69$ & 0 & 3.54 & 772 \\
\hline 06476500 & $\begin{array}{l}\text { Sand Creek near } \\
\text { Alpena, S. Dak. }\end{array}$ & 40.7 & 261 & 0 & $3 / 50-9 / 85$ & 0 & 8.33 & 2,240 \\
\hline 06477150 & $\begin{array}{l}\text { Rock Creek near } \\
\text { Fulton, S. Dak. }\end{array}$ & 9.5 & 240 & 0 & $10 / 66-9 / 72$ & 0 & 9.01 & 2,040 \\
\hline 06477500 & $\begin{array}{l}\text { Firesteel Creek near } \\
\text { Mount Vernon, S. Dak. }\end{array}$ & 30.2 & 521 & 0 & $9 / 55-9 / 85$ & 0 & 22.9 & 6,610 \\
\hline 06478052 & $\begin{array}{l}\text { Enemy Creek near } \\
\text { Mitchell, S. Dak. }\end{array}$ & $7 \cdot 3$ & 163 & 0 & $10 / 75-9 / 85$ & 0 & 12.6 & 4,280 \\
\hline 06478083 & $\begin{array}{l}\text { Plerre Creek near } \\
\text { Alexandria, S. Dak. }\end{array}$ & 6.5 & 78.7 & 0 & $10 / 81-9 / 83$ & 1.5 & 2 & 119 \\
\hline 06478320 & $\begin{array}{l}\text { Plum Creek near } \\
\text { Mill town, S. Dak. }\end{array}$ & .9 & 55.2 & 0 & $10 / 81-9 / 83$ & 0 & 2 & 774 \\
\hline 06478390 & $\begin{array}{l}\text { Wolf Creek near } \\
\text { Clayton, S. Dak. }\end{array}$ & 4.1 & 396 & 0 & $10 / 75-9 / 85$ & 0 & 37.8 & 6,520 \\
\hline 06478420 & $\begin{array}{c}\text { Lonetree Creek near } \\
\text { Olivet, S. Dak. }\end{array}$ & .7 & 110 & 0 & $10 / 81-9 / 83$ & 0 & 2 & 1,090 \\
\hline 06478514 & $\begin{array}{l}\text { Beaver Creek near } \\
\text { Yankton, S. Dak. }\end{array}$ & 1.2 & 145 & 0 & $10 / 81-9 / 83$ & 0 & 2 & 1,110 \\
\hline
\end{tabular}

'Tributary does not discharge directly to the James River.

${ }^{2}$ Average discharge for period of record has not been computed. 
The frequency analyses were made on the main-stem gages using records subsequent to the closure of Jamestown Dam in May 1953. Jamestown Reservoir, located near Jamestown, North Dakota, has a total capacity of 220,978 acre-ft, of which 185,435 acre-ft are for flood control (U.S. Bureau of Reclamation, 1985).

The results of the analysis of instantaneous peak flows are contained in table 3 and the results of the analys is of summer discharges are contained in table 4. Frequency curves for instantaneous peak flow are contained in the Supplemental Information section (figs. 9-16) at the back of the report. Frequency curves for the maximum daily mean flow during June, July, and August are contained in $\mathrm{f}$ igures 17-24 in the Supplemental Information section. The frequency analyses for the gaging stations near stratford and near Mitchell should be interpreted with caution because of the shorter periods of record.

\section{Tributary Locations}

Benson (1983) indicated that improved drainage area data for the James River basin would facilitate improved interpretation of the tributary frequency analyses. This is because most of the tributary gaging stations are located several miles upstream from the mouths. With complete drainage area data, frequency data for the gaged tributaries could be extended from the gage to the mouth by a drainage area ratio (Chow, 1964; Linsley and Franzini, 1964; Linsley and others, 1949). Frequency data for ungaged tributaries could be developed using the drainage area data in conjunction with methods developed by Becker (1974). A summary of the drainage area data which were used to develop the tributary frequency results are contained in table 5.

\section{Gaged Tributaries}

Results of the frequency analyses for the gaged tributaries are contained in table 6 (instantaneous peak flow) and table 7 (summer flow). Extension of the frequency data from each tributary gaging station to the confluence with the James River was accomplished by multiplying the gaging station data by the square root of the ratio of the drainage areas in accordance with the following relation:

$$
Q_{m}=Q_{g}\left(A_{m} / A_{g}\right)^{0.5}
$$

where

$$
\begin{aligned}
& Q_{m}=\text { discharge at mouth of tributary, } \\
& Q^{g}=\text { discharge at gaging station, } \\
& A_{m}=\text { drainage area of tributary at mouth, and } \\
& A_{g}=\text { drainage area of tributary at gage. }
\end{aligned}
$$

The results of extension of the tributary frequency data from the gage to the confluence with the James River are contained in table 8 . 










Table 5.--Drainage area data for tributarles which discharge directly into the James River within South Dakota

\begin{tabular}{|c|c|c|c|c|}
\hline Tributary name & $\begin{array}{l}\text { Drainage } \\
\text { area upstream } \\
\text { from mouth } \\
\text { (square } \\
\text { miles) }\end{array}$ & $\begin{array}{l}\text { Drainage } \\
\text { area upstream } \\
\text { from gage } \\
\text { (square } \\
\text { miles) }\end{array}$ & $\begin{array}{l}\text { Non-contributing } \\
\text { drainage area } \\
\text { upstream from } \\
\text { gage or mouth } \\
\text { (square miles) }\end{array}$ & $\begin{array}{l}\text { Square root } \\
\text { of ratio of } \\
\text { contributing } \\
\text { drainage area }\end{array}$ \\
\hline Dry Run (Mud Lake) ${ }^{2}{ }^{3}$ & 122 & - & 53.2 & -- \\
\hline Elm River & 1,536 & 1,493 & 444 & 1.0203 \\
\hline Crow Creek ${ }^{4}$ & 836 & - & 185 & - \\
\hline Moccasin Creek & 387 & 304 & 0 & 1.1283 \\
\hline Mud Creek (North) ${ }^{2}$ & 782 & 738 & 64.2 & 1.0321 \\
\hline Snake Creek & 2,657 & 2,657 & 48.4 & 1.0000 \\
\hline Turtle Creek & 1,499 & 1,481 & 0 & 1.0061 \\
\hline Dry Run (North) ${ }^{2}$ & 213 & 201 & 0 & 1.0294 \\
\hline Timber Creek & 617 & -- & 30.8 & - \\
\hline Foster Creek ${ }^{5}$ & 243 & -- & 0 & -- \\
\hline Shue Creek & 171 & -- & 0 & -- \\
\hline Stony Run (West) ${ }^{2}$ & 61.7 & -- & 0 & -- \\
\hline Cain Creek & 381 & -- & 0 & -- \\
\hline Pearl Creek & 287 & -- & 0 & -- \\
\hline Stony Run (East) ${ }^{2}$ & - $\quad 37.1$ & -- & 0 & -- \\
\hline Redstone Creek & 264 & -- & 0 & -- \\
\hline Sand Creek & 397 & 261 & 0 & 1.2333 \\
\hline Jim Creek & 102 & -- & 0 & -- \\
\hline Dry Run (East) ${ }^{2}$ & 11.4 & -- & 0 & -- \\
\hline Dry Run (South) ${ }^{2}$ & 222 & -- & 0 & -- \\
\hline Rock Creek & 280 & 240 & 0 & 1.0801 \\
\hline Firesteel Creek $^{6}$ & 699 & 521 & 0 & 1.1583 \\
\hline Enemy Creek & 179 & 163 & 0 & 1.0479 \\
\hline Johnson Creek & 53.5 & -- & 0 & -- \\
\hline Plerre Creek & 93.4 & 78.7 & 0 & 1.0894 \\
\hline Bloom Creek & 40.5 & -- & 0 & -- \\
\hline Twelvemile Creek & 276 & -- & 0 & -- \\
\hline Dry Creek & 131 & -- & 0 & -- \\
\hline Plum Creek & 55.5 & 55.2 & 0 & 1.0027 \\
\hline Wolf Creek & 398 & 396 & 0 & 1.0025 \\
\hline Furlong Creek & 16.8 & -- & 0 & -- \\
\hline Lonetree Creek & 110 & 110 & 0 & 1.0000 \\
\hline Dawson Creek & 68.9 & -- & 0 & -- \\
\hline Prairie Creek & 54.9 & -- & 0 & -- \\
\hline Mud Creek (South) ${ }^{2}$ & 27.4 & -- & 0 & -- \\
\hline Beaver Creek & 145 & 145 & 0 & 1.0000 \\
\hline
\end{tabular}

${ }^{1}$ The square root of the ratio of the contributing drainage area upstream from the mouth and the contributing drainage area upstream from the gage.

${ }^{2}$ Names in parenthesis added to differentiate between tributaries with identical names.

${ }^{3}$ Discharges into Mud Lake within Sand Lake National Wildlife Refuge.

${ }^{4}$ Crow Creek flows enter James River via Crow Creek Drain.

${ }^{5}$ Foster Creek flows through Lake Byron and is thereby regulated before entering James River.

${ }^{6}$ Eiresteel Creek flows through Lake Mitchell and is thereby regulated before entering James River. 















Estimates of peak discharges for the 2-,5-, 10-, 25-, 50-, and 100-year recurrence interval floods were computed using the following relations developed by Becker (1974). Equations are:

$$
\begin{aligned}
& Q_{2}=0.030 A^{0.47} P^{2.92} \\
& Q_{5}=0.458 A^{0.49} P^{2.26} \\
& Q_{10}=1.78 A^{0.50} P^{1.92} \\
& Q_{25}=7.52 A^{0.51} P^{1.54} \\
& Q_{50}=30.3 A^{0.52} P^{1.09} \\
& Q_{100}=78.4 A^{0.52} P^{0.84}
\end{aligned}
$$

where

$$
\begin{aligned}
Q= & \text { discharge in cubic feet per second, } \\
A= & \text { contributing drainage area in square miles ( } 1 \text { imited to areas less } \\
& \text { than } 4,000 \mathrm{mi}^{2} \text { ), and } \\
P= & \text { mean annual precipitation, in inches, minus } 11 \text { inches. }
\end{aligned}
$$

Estimated flood flows (instantaneous peak discharge) of selected ungaged tributaries at their confluence with the James River are contained in table 9. Becker's method is for peak flows and is not applicable to estimation of summer discharges.

\section{ANALYSIS OF FLOW DURATION}

Duration hydrograph plots (Wilson, 1981) were prepared for each of the main-stem gaging stations using daily mean discharge data stored in the U.S. Geological Survey's WATSTORE daily-values file. Each plot shows the daily discharge values for the 20-, 50-, and 80-percent exceedance values, as well as the minimum and maximum recorded daily values for each day of the year. A 20-percent exceedance value represents a daily mean discharge that can be expected to be equaled or exceeded on the indicated day an average of once in 5 years (sometimes referred to as a 5-year flow). Likewise, the 80-percent value represents a daily mean discharge which can be expected to be equaled or exceeded on the indicated day an average of 4 years out of 5 (a 1.25-year flow). The 50-percent value (or median) can be expected to be equaled or exceeded on the indicated day an average of once in 2 years (a 2-year flow).

The computer program used to generate the duration hydrographs requires that the analysis be conducted for a period of $9,19,29,39$, or 49 years. Therefore, it was not possible to use the entire period of record for the analysis of each gaging station. The period of record used for each duration hydrograph is specified in the discussion of the duration hydrographs for each of the James River main-stem gages in South Dakota. 







ono Nmingo










-






$\because$



in in in in in in in in in in in









7 
James River at Columbia

The duration hydrograph for the James River at Columbia (station no. 06471000) is shown in figure 2. The hydrograph is based on the 39 years of discharge record from water year 1947 through water year 1985.

The bankfull capacity of the James River between Columbia and Stratford has been estimated to be as little as 200 to $300 \mathrm{ft}^{3} / \mathrm{s}$ at certain locations (U.S. Bureau of Reclamation, 1977; Missouri River Basin Commission, 1980a; and Benson, 1983). The duration hydrograph indicates that a discharge of $200 \mathrm{ft}^{3} / \mathrm{s}$ can be expected to be equaled or exceeded on any individual day at least 20 percent of the time from April 7 through July 31 and at least 50 percent of the time from April 16 through April 19 and from April 24 through May 17 (table 10 in the Supplemental Information section). A discharge of $200 \mathrm{ft}^{3} / \mathrm{s}$ has never been exceeded at Columbia during the period from December 19 through March 20.

The 50-percent exceedance discharge (median) at Columbia ranges from zero on many days to $325 \mathrm{ft}^{3} / \mathrm{s}$ on May 10 and is less than $10 \mathrm{ft}^{3} / \mathrm{s}$ from August 3 through August 11, August 14 through March 25, and March 31 through April 2 . Zero flow has occurred on each day of the year sometime during the 39 years which were analyzed. In fact, zero flow was recorded for 623 consecutive days from JuIy 13, 1958, through March 26, 1960. Zero flow can be expected 50 percent of the time on September 14 and on any individual day between September 17 and October 28 and between December 22 and March 12 .

Figure 2 and table 10 further indicate that a daily mean discharge of $1,010 \mathrm{ft}^{3} / \mathrm{s}$ can be expected to be equaled or exceeded an average of once in 5 years (20-percent flow) on April 25, $325 \mathrm{ft}^{3} / \mathrm{s}$ can be expected to be equaled or exceeded an average of once in 2 years (50-percent flow) on May 10, and $49 \mathrm{ft}^{3} / \mathrm{s}$ can be expected to be equaled or exceeded an average of once in 1.25 years (80-percent flow) on May 1 . These are the maximums of the 20-, 50-, and 80-percent discharges in figure 2 and table 10.

\section{James River near Stratford}

Continuous discharge records for the James River near Stratford (station no. 06472000) were collected from March 1950 through September 1972 and again during water year 1977. The duration hydrograph analysis was conducted for the 19 water years from 1954 through 1972 and the hydrograph plot is shown in figure 3 .

The hydrograph is quite similar to the one for Columbia discussed previously. The duration hydrograph indicates that flows exceeding $200 \mathrm{ft}^{3} / \mathrm{s}$ can be expected to be equaled or exceeded on any individual day at least 20 percent of the time from March 24 through August 17 and at least 50 percent of the time from April 29 through May 15, May 17-18, and May 21-24 (table 11 in the Supplemental Information section). Zero flow was recorded at Stratford for 601 consecutive days from August 4, 1958, through March 26, 1960. 







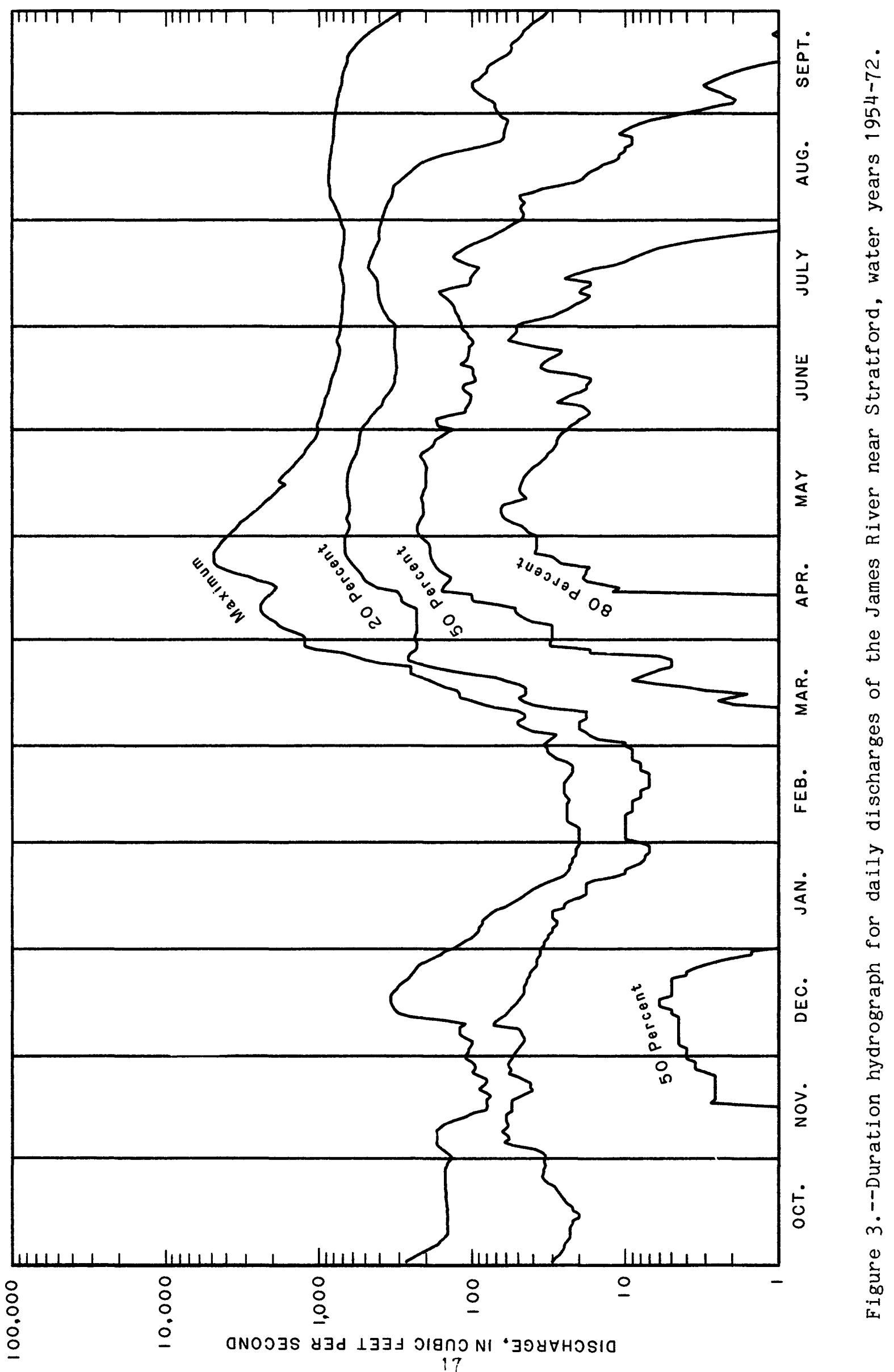


The duration hydrograph for the James River at Ashton (station no. 06473000) is presented in figure 4. The hydrograph is based on 39 years of discharge record (water years 1947 through 1985).

The bankfull capacity between Stratford and Ashton has been estimated to range from 500 to $1,000 \mathrm{ft}^{3} / \mathrm{s}$ (Benson, 1983). The duration hydrograph indicates that discharges exceeding $500 \mathrm{ft}^{3} / \mathrm{s}$ have occurred at Ashton during March 21 through September 28 (table 12 in the Supplemental Information section). The 20-percent exceedance daily mean discharge is greater than $1,000 \mathrm{ft}^{3} / \mathrm{s}$ from May 13 through May 16 and greater than $500 \mathrm{ft}^{3} / \mathrm{s}$ from April 14 through July 7, July 18-29, and August 2-6. The 10-percent exceedance daily mean discharge (table 12) is greater than $1,000 \mathrm{ft}^{3} / \mathrm{s}$ on any individual day from April 16 through May 29.

The median discharge at Ashton ranges from $0.1 \mathrm{ft}^{3} / \mathrm{s}$ on January 31 to $399 \mathrm{ft}^{3} / \mathrm{s}$ on May 13 and is less than $10 \mathrm{ft}^{3} / \mathrm{s}$ from August 31 through March 19. As with the previous stations, zero flow has occurred on each day of the year sometime during the period of record. Zero flow was recorded at Ashton for 590 consecutive days from August 14, 1958, through March 25, 1960.

\section{James River near Redfield}

The duration hydrograph for the James River near Redfield (station no. 06475000 ) is presented in figure 5. The hydrograph is based on 29 years of discharge record (water years 1957 through 1985).

The bankfull capacity between Ashton and Redfield has been estimated to be as little as $800 \mathrm{ft}^{3} / \mathrm{s}$ (Benson, 1983). The 20-percent exceedance daily mean discharge exceeds $800 \mathrm{ft}^{3} / \mathrm{s}$ for 61 days from April 3 through June 2 (table 13 in the Supplemental Information section). Thus, flow exceeding bankfull capacity between Ashton and Redfield can be expected to occur on any given day between April 3 and June 2 an average of at least once every 5 years. The 10-percent exceedance daily mean discharge exceeds $800 \mathrm{ft}^{3} / \mathrm{s}$ from March 20 through June 7, June 14, June 17-19, June 21 through July 7, and July 13-17.

The median discharge at the gage near Redfield ranges from $1.5 \mathrm{ft}^{3} / \mathrm{s}$ on February 1 to $434 \mathrm{ft}^{3} / \mathrm{s}$ on May 17 and the discharge is less than $10 \mathrm{ft}^{3} / \mathrm{s}$ from January 6 through March 11 and from September 19 through November 23. Zero flow at the gage near Redfield has never occurred during the periods April 5 through May 13, May 17-19, and May 23-24 although the discharge has been less than $3 \mathrm{ft}^{3} / \mathrm{s}$ during these periods. Zero flow was recorded at Redfield from August 15, 1958, through March 1, 1959 (199 consecutive days), and from June 11, 1959, through March 26, 1960 (290 consecutive days).

\section{James River at Huron}

The duration hydrograph for the James River at Huron (station no. 06476000) is presented in figure 6. The hydrograph is based on 39 years of discharge record (water years 1947 through 1985). 















Much of the reach between Redfield and Huron is in backwater from the James Diversion Dam or from the Third Street Dam. The bankfull capacity between the James Diversion Dam and the gage at Huron is about 3,800 $\mathrm{ft}^{3} / \mathrm{s}$ (Missouri River Basin Commission, 1980a). The duration hydrograph indicates that maximum daily mean discharges exceeding bankfull capacity have occurred Juring the period March 25 through May 12 and during May 18 through June 8 . The 20-percent exceedance daily mean discharge does not exceed $3,800 \mathrm{ft}^{3} / \mathrm{s}$ and the 10-percent exceedance daily mean discharge only exceeds $3,800 \mathrm{ft}^{3} / \mathrm{s}$ on April 7 (table 14 in the Supplemental Information section).

The median discharge at Huron ranges from zero on many days in october and November to $478 \mathrm{ft}^{3} / \mathrm{s}$ on May 9 and May 26 and is less than $20 \mathrm{ft}^{3} / \mathrm{s}$ from September 2-18 and from September 21 through March 6. Zero flow was recorded on each day of the year sometime during the analysis period.

\section{James River near Forestburg}

The duration hydrograph for the James River near Forestburg (station no. 06477000) is presented in figure 7. The hydrograph is based on the 29 years of discharge record from water year 1957 through water year 1985.

The bankfull capacity between Huron and Forestburg is estimated to be as little as 1,200 $\mathrm{ft}^{3} / \mathrm{s}$ (Benson, 1983). The 20-percent exceedance daily mean discharge equals or exceeds $1,200 \mathrm{ft}^{3} / \mathrm{s}$ during March 29 through April 1 , April 13-20, May 9-10, and May 17-18 (table 15 in the Supplemental Information section). The 10-percent exceedance daily mean discharge equals or exceeds $1,200 \mathrm{ft}^{3} / \mathrm{s}$ during March 14 through June 11 and June 19-29.

The median discharge at the gage near Forestburg ranges from $8 \mathrm{ft}^{3} / \mathrm{s}$ on October 2 to $438 \mathrm{ft}^{3} / \mathrm{s}$ on May 27 and exceeds $50 \mathrm{ft}^{3} / \mathrm{s}$ from March 12 through August 2 and August 9-10. Zero flow has been recorded on July 1-2, July 6 through August 2, and August 4 through March 10.

\section{James River near Scotland}

The duration hydrograph for the James River near Scotland (station no. 06478500) is presented in figure 8. The hydrograph is based on the 49 years of discharge record from water year 1937 through 1985.

The bankfull capacity of the James River between Forestburg and Scotland ranges from 2,000 to $3,400 \mathrm{ft}^{3} / \mathrm{s}$ (Missouri River Basin Commission, 1980a). Discharges exceeding $3,400 \mathrm{ft}^{3} / \mathrm{s}$ have been recorded on March 15-17 and March 20 through July 22 (table 16 in the Supplemental Information section). The 10-percent exceedance daily mean discharge exceeds $3,400 \mathrm{ft}^{3} / \mathrm{s}$ during March 28 through April 23 and June 12-13. Daily mean discharges equal to or greater than 2,000 $\mathrm{ft}^{3} / \mathrm{s}$ have been recorded during March 3 through July 29 , August 10-14, and August 20. The 20-percent exceedance discharge equals or exceeds 2,000 $\mathrm{ft}^{3} / \mathrm{s}$ during March 27 through April 22 and the 10-percent exceedance discharge equals or exceeds $2,000 \mathrm{ft}^{3} / \mathrm{s}$ during March 19 through June 8 and June 10 through July 3 .

The median discharge at the gage near Scotland ranges between $24 \mathrm{ft}^{3} / \mathrm{s}$ (October 22) and $864 \mathrm{ft}^{3} / \mathrm{s}$ (March 30) and exceeds $100 \mathrm{ft}^{3} / \mathrm{s}$ from March 9 through August 9 . Zero flow has been recorded during January 30 through February 4, August 4 through September 1, and September 5 through December 4. 










The duration hydrographs for the James River main-stem gaging stations indicate that the river has potential for relatively high flows during spring from snowmelt and during early summer from thunderstorms. The hydrographs also indicate that the river has extended periods of no flow from late summer until spring snowmelt. Upstream from Redfield, zero-flow conditions have occurred on the James River within South Dakota in excess of an entire year.

The use of the duration hydrograph analysis in conjunction with bankfull capacity data provides a tool to evaluate the potential flooding effects of additional flows in the James River. For instance, the importation of additional flow into the river reduces the river's capability to convey natural flows by a volume equal to the imported flow. Therefore, the duration of flooding subsequent to flow importation can be analyzed by subtracting the imported flow from the bankfull capacity and then comparing this to the applicable duration hydrograph (Benson, 1983). For example, importation of $100 \mathrm{ft}^{3} / \mathrm{s}$ of flow would impair the river's capability to convey natural flows by that same $100 \mathrm{ft}^{3} / \mathrm{s}$. In an area where the bankfull capacity is as little as $200 \mathrm{ft}^{3} / \mathrm{s}$ (such as between Columbia and stratford), the importation of $100 \mathrm{ft}^{3} / \mathrm{s}$ would reduce the river's capacity to convey natural flows from 200 to $100 \mathrm{ft}^{3} / \mathrm{s}$. From figure 3 and table 11, the time during which the 5 -year daily mean discharge (20-percent exceedance probability) exceeds bankfull discharge would be increased from 147 days (March 24 through August 17) to 153 days (March 21 through August 20). The impact on the median discharge (50-percent exceedance probability) would be much greater in that the number of days with discharge equal to or greater than $200 \mathrm{ft}^{3} / \mathrm{s}$ would be increased from 23 to 94 days. Where the bankfull capacity is as 1 ittle as $500 \mathrm{ft}^{3} / \mathrm{s}$ (such as between Stratford and Ashton), importation of $100 \mathrm{ft}^{3} / \mathrm{s}$ of flow into the river would reduce the river's capacity to convey natural flows from 500 to $400 \mathrm{ft}^{3} / \mathrm{s}$. From figure 4 and table 12, the time during which the 5-year daily mean discharge exceeds bankfull discharge would be increased from 102 days (April 14 through July 7, July 18-29, and August 2-6) to 132 days (April 6, April 8 through August 13, and August 15-17). Similar comparisons can be made for other imported flow amounts and at other locations.

\section{ANALYSIS OF CHANNEL-FORMING FLOW}

Factors Affecting Channel Formation

The shape of the cross section of a river channel at any location is a function of the flow, the quantity and character of the sediment moving through the section, and the character and composition of the materials making up the bed and banks of the channel. The shape of a channel as viewed from above, referred to as channel pattern, is closely related to the amount and character of the available sediment and to the quantity and variability of the discharge. River channels having a ratio of channel length to valley length (sinuousity) of greater than 1.5 are considered to be meandering (Leopold and others, 1964). The sinuousity of the James River in South Dakota is about 2.25. Chow (1964) states that at least four variables (valley slope, sediment load, discharge, and the characteristics of the bed and bank material) are known to control the shape of the channel and the process of meandering. 
There is evidence to indicate that the channel pattern of the James River changes very slowly. With the exception of some isolated reaches where human modifications have been made to the channel alignment and where a few natural oxbow cutoffs have occurred, the current channel pattern is very similar to the pattern that existed more than 60 years ago. Examination of data presented by Reeves (1922) also indicates that the general character of cross sections of the James River channel through South Dakota in 1922 was similar to current conditions. Reeves states: "Through parts of Spink and Brown Counties the channel is so small and badly choked with trees, deadfall, and other obstructions that extensive clearing operations are necessary." Reeves further indicated that sandbars, deadfall, and other channel obstructions were present in the river channel in the southern portion of the state.

Although not specifically documented, local residents maintain that the bankfull capacity in many areas has decreased in recent years due to bank sloughing or to the accumulation of sediment. Areas of obvious siltation are usually found near the mouth of a tributary or upstream from obstructions such as rock dams and $\log$ jams.

It was beyond the scope of this study to determine the causes of bank sloughing or the sources of sediment reaching the James River, or the specific factors influencing deposition in the main channel. Rather, the objective was to attempt to identify discharges most responsible for the present channel configuration of the James River in South Dakota. Ideally, this would involve the determination of a "dominant" or an "effective" discharge. Dominant discharge is defined as "a discharge that molds a riverbed" (Johnson, 1970) and effective discharge is defined as "a discharge that maintains the present channel cross section" (Karlinger and others, 1983). Detailed sediment data are required to determine either of these discharges. However, sediment data have not been collected at the main-stem gaging stations on a regular basis, except for water years 1982 and 1983 when daily suspended sediment data were collected at the gages near Forestburg, Scotland, and Yankton (Little, 1983 and 1985).

Bankfull discharge at a river cross section is the flow that just fills the channel to the tops of the banks. Bankfull discharge is thought to also have an important influence on the cross-sectional shape and size of the channel (Williams, 1978). Determination of the bankfull capacity of the James River in South Dakota has been made by the U.S. Bureau of Reclamation (1977), the U.S. Army Corps of Engineers (Missouri River Basin Commission, 1980a), and the U.S. Geological Survey (Benson, 1983).

Because insufficient sediment data are available to determine a "dominant" or an "effective" discharge on the James River in South Dakota and because bankfull discharge is thought to also have an important influence on the channel cross section, frequency data (peak flow and maximum daily mean discharge during June, July, and August) and duration data for daily mean discharges were related to bankfull capacity to assess channel-forming flow.

\section{Relation Between Bankfull-Capacity, Flood-Frequency, and Flow-Duration Data}

Between Sand Lake and the confluence with the Elm River, the average bankfull capacity of the James River was estimated to be $200 \mathrm{ft}^{3} / \mathrm{s}$ (Missouri River Basin Commission, 1980a). The recurrence interval of a peak flow of 
$200 \mathrm{ft}^{3} / \mathrm{s}$ at the gage at Columbia is about 1.4 years ( $\mathrm{fig} .9$ ). The recurrence interval of a maximum daily mean discharge of this magnitude during June, July, or August (that is, a summer discharge) is only slightly more than 2 years (fig. 17). The duration hydrograph (fig. 2) indicates that a daily mean discharge of $200 \mathrm{ft}^{3} / \mathrm{s}$ has at least a 20-percent chance of being equaled or exceeded on any one day during the 116-day period from April 7 through July 31 and has at least a 50-percent chance of being equaled or exceeded on any one day during the 28 days from April 16-19 and April 24 through May 17. The duration hydrograph for Columbia further indicates that a daily mean discharge of $325 \mathrm{ft}^{3} / \mathrm{s}$ can be expected to be equaled or exceeded an average of 1 year in 2 (50-percent flow) on May 10; on other dates the probability of exceedance is less than 1 in 2 years.

Between the Elm River and the gage near Stratford, the bankfull capacity was estimated to range between 200-300 and $700 \mathrm{ft}^{3} / \mathrm{s}$ (Benson, 1983). The recurrence interval of an instantaneous peak flow of $200 \mathrm{ft}^{3} / \mathrm{s}$ at the gage near stratford is about 1.4 years and the recurrence interval of an instantaneous peak flow of $700 \mathrm{ft}^{3} / \mathrm{s}$ is about 3.4 years ( $\mathrm{fig}$. 10). The recurrence interval of a summer discharge (that is, maximum daily mean discharge during June, July, or August) of $200 \mathrm{ft}^{3} / \mathrm{s}$ at the gage near Stratford is about 1.7 years (fig. 18). The duration hydrograph for stratford (fig. 3) indicates that a daily mean discharge of $200 \mathrm{ft}^{3} / \mathrm{s}$ has at least a 20-percent chance of being equaled or exceeded on any given day during the 147-day period from March 24 through August 17 and at least a 50-percent chance of being equaled or exceeded on any individual day from April 29 through May 15, May 17-18, and May 21-24 (23 days).

Between Stratford and the gage at Ashton, the bankfull capacity was estimated to range between 500 and $1,000 \mathrm{ft}^{3} / \mathrm{s}$ (Missouri River Basin Commission, 1980a). The recurrence interval of an instantaneous peak flow of $500 \mathrm{ft}^{3} / \mathrm{s}$ at the gage at Ashton is about 2.2 years and the recurrence interval of a $1,000 \mathrm{ft}^{3} / \mathrm{s}$ peak flow is about 4.2 years ( $\mathrm{fig}$. 11). A daily mean discharge of $500 \mathrm{ft}^{3} / \mathrm{s}$ has a 20-percent chance of being equaled or exceeded at Ashton on any one day from April 14 through July 7, July 18-29, and August 2-6 (102 days). The 50-percent discharge (median) does not equal or exceed $500 \mathrm{ft}^{3} / \mathrm{s}$ at Ashton. The duration hydrograph table for Ashton (table 12) shows that a daily mean discharge of $500 \mathrm{ft}^{3} / \mathrm{s}$ has a 10-percent chance of being equaled or exceeded on any one day from March 30 through August 17 (141 days).

Between Ashton and the gage near Redfield, the bankfull capacity was estimated to be as 1 ittle as $800 \mathrm{ft}^{3} / \mathrm{s}$ (Benson, 1983). The recurrence interval of an instantaneous peak flow of $800 \mathrm{ft}^{3} / \mathrm{s}$ at the gage near Redfield is about 2.3 years ( $\mathrm{fig} .12$ ). A daily mean discharge of $800 \mathrm{ft}^{3} / \mathrm{s}$ has at least a 20-percent chance of being equaled or exceeded on any one day from April 3 through June 2 (61 days). The 50-percent discharge (median) does not equal or exceed $800 \mathrm{ft}^{3} / \mathrm{s}$ at the gage near Redfield. The 10-percent discharge exceeds $800 \mathrm{ft}^{3} / \mathrm{s}$ for 106 days from March 20 through June 7 , June 14 , June 17-19, June 21 through July 7, and July 13-17 (table 13).

Most of the reach between Redfield and Huron is in backwater from the James Diversion Dam or the Third Street Dam. The 1979 bankfull capacity between the James Diversion Dam and the gage at Huron was estimated to be about $3,800 \mathrm{ft}^{3} / \mathrm{s}$. The recurrence interval of an instantaneous peak flow of 
3,800 $\mathrm{ft}^{3} / \mathrm{s}$ at the Huron gage is about 8 years (fig. 13). The duration hydrograph analysis indicates that daily mean flows exceeding 3,800 $\mathrm{ft}^{3} / \mathrm{s}$ have only been recorded at Huron during March 25 through May 12 and during May 18 through June 8. Table 14 shows that there is at least a 10-percent chance of a discharge of $3,800 \mathrm{ft}^{3} / \mathrm{s}$ being equaled or exceeded on only one day of the year (April 7). The 20-percent and 50-percent discharges do not exceed $3,800 \mathrm{ft}^{3} / \mathrm{s}$ at Huron.

The bankfull capacity between Huron and the gage near Forestburg was estimated to be as little as 1,200 $\mathrm{ft}^{3} / \mathrm{s}$ (Benson, 1983). The recurrence interval of an instantaneous peak flow of $1,200 \mathrm{ft}^{3} / \mathrm{s}$ at the gage near Forestburg is about 2 years (fig. 14). Figure 7 shows that a daily mean discharge of $1,200 \mathrm{ft}^{3} / \mathrm{s}$ has at least a 20-percent chance of being equaled or exceeded on any given day during the 16 days from March 29 through April 1 , April 13-20, May 9-10, and May 17-18. Table 15 shows that there is a 10-percent chance that the daily mean discharge will equal or exceed $1,200 \mathrm{ft}^{3} / \mathrm{s}$ at the gage near Forestburg on any given day from March 14 through June 11 and June 19-29 (101 days).

The bankfull capacity between Forestburg and the gage near Mitchell was estimated to range between 1,000 and $3,400 \mathrm{ft}^{3} / \mathrm{s}$ (Missouri $\mathrm{R}$ iver Basin Commission, 1980a). The recurrence interval for an instantaneous peak flow of $1,000 \mathrm{ft}^{3} / \mathrm{s}$ at the gage near Mitchell is about 1.4 years and for a peak flow of $3,400 \mathrm{ft}^{3} / \mathrm{s}$ is about 4.5 years ( $\mathrm{fig}$. 15). The duration hydrograph analysis was not made for the gage near Mitchell due to insufficient data.

The bankfull capacity of the James River between Mitchell and the gage near Scotland was estimated to range from 2,000 to 3,400 $\mathrm{ft}^{3} / \mathrm{s}$ (Missouri River Basin Commission, 1980a). The recurrence interval for an instantaneous peak flow of $2,000 \mathrm{ft}^{3} / \mathrm{s}$ at the gage near scotland is slightly less than 2 years and the recurrence interval for a peak flow of $3,400 \mathrm{ft}^{3} / \mathrm{s}$ at the gage near Scotland is slightly less than 3 years ( $f$ ig. 16). There is at least a 20-percent chance that a daily mean discharge of $2,000 \mathrm{ft}^{3} / \mathrm{s}$ will be equaled or exceeded at the gage near Scotland on any given day during March 27 through April 22 ( 27 days) and at least a 10-percent chance that 2,000 $\mathrm{ft}^{3} / \mathrm{s}$ will be equaled or exceeded on any individual day for 106 days from March 19 through July 3, excluding June 9 (table 16). The 50-percent discharge (median) does not exceed $2,000 \mathrm{ft}^{3} / \mathrm{s}$.

\section{Summary of Analys is of Channel-Eorming Flow}

Table 17 summarizes the recurrence intervals of peak discharges which produce bankfull conditions in the reach upstream of various gaging stations, as well as the number of days the daily mean discharge exceeds bankfull capacity for various exceedance probabilities.

As an explanation of the data in table 17, for the reach upstream from Columbia, the recurrence interval of an instantaneous peak discharge at Columbia which exceeds bankfull capacity $\left(200 \mathrm{ft}^{3} / \mathrm{s}\right)$ is 1.4 years. There is at least a 10-percent chance that the daily mean discharge at Columbia will equal or exceed $200 \mathrm{ft}^{3} / \mathrm{s}$ for 154 days during the year, at least a 20-percent chance of equaling or exceeding $200 \mathrm{ft}^{3} / \mathrm{s}$ for 116 days, and at least a 50percent chance that bankfull capacity will be exceeded for 28 days per year. Similar evaluations of the data for the other gaging stations can be made. 
Table 17.--Recurrence interval of instantaneous peak flow equal to minimum bankfull capacity and days for which minimum bankfull capacity is equaled or exceeded for streamflow-gaging stations on the James River in south Dakota

\begin{tabular}{|c|c|c|c|c|c|}
\hline \multirow{2}{*}{$\begin{array}{l}\text { James River } \\
\text { gaging station }\end{array}$} & \multirow{2}{*}{$\begin{array}{l}\text { Minimum bankfull } \\
\text { capacity, in } \\
\text { cubic feet } \\
\text { per second, } \\
\text { in reach } \\
\text { upstream } \\
\text { from gage }\end{array}$} & \multirow{2}{*}{$\begin{array}{l}\text { Recurrence } \\
\text { interval, in } \\
\text { years, of peak } \\
\text { flow equal to } \\
\text { minimum } \\
\text { bankfull } \\
\text { capacity }\end{array}$} & \multicolumn{3}{|c|}{$\begin{array}{l}\text { Days for which minimum } \\
\text { bankfull capacity is } \\
\text { equaled or exceeded for } \\
\text { exceedance probability, } \\
\text { in percent }\end{array}$} \\
\hline & & & 10 & 20 & 50 \\
\hline at Columbia & 200 & 1.4 & 154 & 116 & 28 \\
\hline $\mathrm{nr}$ Stratford & 200 & 1.4 & 168 & 147 & 23 \\
\hline at Ashton & 500 & 2.2 & 141 & 102 & 0 \\
\hline nr Redfield & 800 & 2.3 & 106 & 61 & 0 \\
\hline at Huron & 23,800 & 28.0 & 21 & ${ }^{2} 0$ & ${ }^{2} 0$ \\
\hline nr Forestburg & 1,200 & 2.0 & 101 & 16 & 0 \\
\hline nr Mitchell & 1,000 & 1.4 & 3 & 3 & 3 \\
\hline $\mathrm{nr}$ Scotland & 2,000 & 2.0 & 106 & 27 & 0 \\
\hline
\end{tabular}

${ }^{1}$ Based on Water Resources Council Bulletin 17B flood-frequency analysis. ${ }^{2}$ Most of reach is in backwater from James Diversion Dam and Third Street Dam. ${ }^{3}$ Duration hydrograph analysis not performed due to lack of data.

In summary, flows which produce bankfull conditions occur quite frequently on the James River in South Dakota. The frequency of occurrence of bankfull flows on the James River suggests one of two things: (1) Channel formation is occurring almost continuously, or (2) channel formation is approaching an equilibrium condition. The slowness with which changes in channel configuration occur, as evidenced by the similarity between channel conditions which Reeves observed in 1922 and channel conditions which currently exist, would suggest an equilibrium condition.

The accumulation of sediment probably can be attributed to the flat slope of the James River. The slope of the river is so flat that velocities are not sufficient to carry the sediment being delivered to the river. Collection of detailed sediment data on the James River and on tributaries is necessary in order to ascertain the sources of sediment which are accumulating in the main channel. These sediment data would also facilitate a more detailed evaluation of "dominant flow" or "effective discharge" on the James River.

\section{CONCLUSIONS}

The flood-flow frequency data, when evaluated in conjunction with bankfull-capacity data, indicate that discharges that produce bankfull conditions occur an average of once in about 2 years. Furthermore, the frequency data indicate that the 10-year flood flows, which range from 1,620 cubic feet per second at the gage near Stratford to 8,870 cubic feet per second at the gage near Scotland, cause major flooding on most of the river in South Dakota. 
The frequency analyses of maximum daily mean discharges during June, July, and August were conducted to facilitate Bureau of Reclamation evaluation of "summer" discharges. For the main-stem gaging stations, the 10-year maximum daily mean discharges during June, July, and August are of a similar magnitude to the 5-year instantaneous peak flow discharges.

The flood-flow frequency analyses of the gaged tributaries indicate that the tributaries have potential to contribute substantial flows to the main stem. For instance, the 2-year flow for the Elm River at Westport is 678 cubic feet per second, which equals or exceeds the bankfull capacity of the James River a few miles downstream from its confluence with the main stem. Evaluation of the flood-flow frequency data, in conjunction with bankfull capacity data, reveals other instances where the 2-year tributary flood flows are greater than the channel capacity of the main stem near their confluence.

Determination of the drainage area for the entire James River basin in South Dakota allowed for the extension of flood-flow frequency data from the gaging station location to the mouth for gaged tributaries and allowed for the determination of flood-flow frequency data for ungaged tributaries. The locations of some tributary gaging stations are such that adjustments as much as 13 to 23 percent are required to extend the tributary data from the gage to the mouth. The drainage area data allowed for the determination of frequency data for over 4,100 square miles of tributary drainage within South Dakota.

The duration hydrographs for the James River main-stem gaging stations indicate that the $r i v e r$ has potential for relatively high flows during spring from snowmelt and during early summer from thunderstorms. In the vicinity of Columbia, there is a 50-percent chance that the bankfull capacity will be equaled or exceeded for 28 days per year, a 20-percent chance that bankfull capacity will be exceeded for 116 days per year, and a 10-percent chance that bankfull capacity will be exceeded for 154 days per year. Downstream, at the gage near Scotland, there is a 20-percent chance that bankfull capacity will be equaled or exceeded for 27 days per year and a 10-percent chance that bankfull capacity will be equaled or exceeded for 106 days per year. The hydrographs also indicate that the river has extended periods of no flow from late summer until spring snowmelt. Upstream from Redfield, zero-flow conditions have occurred on the river in excess of an entire year (623 consecutive days at Columbia, 601 consecutive days at the gage near Stratford, and 590 days at Ashton).

Evaluation of dominant discharge was limited by the lack of sediment data on the James River. An evaluation of channel-forming flow was conducted on the basis of an appraisal of discharge data in conjunction with channel capacity and channel geometry. An appraisal of channel cross sections and of the river pattern indicates that the frequent occurrence of bankfull conditions (an average of about every other year) is not causing substantial changes in the river cross section or pattern. This channel stability indicates that channel formation is approaching a state of equilibrium. 
Becker, L.D., 1974, A method for estimating magnitude and frequency of floods in South Dakota: U.S. Geological Survey Water-Resources Investigations Report 35-74, $78 \mathrm{p}$.

Benson, R.D., 1983, A preliminary assessment of the hydrologic characteristics of the James River in South Dakota: U.S. Geological Survey WaterResources Investigations Report 83-4077, $115 \mathrm{p}$.

Benson, R.D., Freese, M.E., Amundson, F.D., and Wipf, V.J., 1987, Drainage areas in the James River basin in eastern South Dakota: U.S. Geological Survey Open-File Map Report 87-572, scale 1:500,000, 1 sheet.

Chow, V.T., 1964, Handbook of applied hydrology: New York, McGraw-Hill, $1453 \mathrm{p}$.

Garrison Diversion Unit Commission, 1984, Final report: U.S. Bureau of Reclamation, Billings, Montana, $59 \mathrm{p}$.

Johnson, H.0., 1970, Current Dutch practice for evaluating river sediment transport processes: Seminar on sediment transport in rivers and reservoirs, 7-9 April 1970, Proceedings, U.S. Army Corps of Engineers, Hydrologic Engineering Center, $10 \mathrm{p}$.

Karlinger, M.R., Eschner, T.R., Hadley, R.F., and Kircher, J.E., 1983, Relation of channel-width maintenance to sediment transport and river morphology: Platte River, south-central Nebraska: U.S. Geological Survey Professional Paper 1277-E, 19 p.

Leopold, L.B., Wolman, M.G., and Miller, J.P., 1964, Fluvial processes in Geomorphology: San Francisco, W. H. Freeman, 522 p.

Linsley, R.K., and Franzini, J.B., 1964, Water-Resources Engineering: New York, McGraw-Hill, $654 \mathrm{p}$.

Little, J.R., 1983, Streamflow and sediment data collected at seven streamgaging stations in the James River basin downstream from Forestburg, South Dakota, from October 1, 1981, to September 30, 1982: U.S. Geological Survey Open-File Report 83-773, 61 p.

--- 1985, Streamflow and sediment data collected at seven stream-gaging stations in the James River basin downstream from Forestburg, South Dakota, from October 1, 1982, to September 30, 1983: U.S. Geological Survey Open-File Report 85-156, S. Dak., 60 p.

Missouri River Basin Commission, 1980a, Flooding technical paper, James River basin subregional analysis, North Dakota-South Dakota: Omaha, Nebr., $74 \mathrm{p}$.

--.- 1980b, Summary report, James River basin subregional analysis, North Dakota-South Dakota: Omaha, Nebr., 125 p. 
Reeves, W.S., 1922, Drainage and flood control investigations in the James and Big Sioux River Valleys: Mitchell, S. Dak., 85 p.

Schumm, S.A. (ed.), 1972, Benchmark Papers in Geology - River Morphology: Stroudsburg, Pa., Dowden, Hutchinson, and Ross, Inc., 429 p.

U.S. Bureau of Reclamation, 1977, Basic data-alternative concepts, James River Water Management: Huron, S. Dak., 40 p.

1985, 1985 Summary of annual operations and 1986 annual operating plan: Billings, Montana, $121 \mathrm{p}$.

U.S. Water Resources Council, 1981, Guidelines for determining flood flow frequency: Washington, D.C., Bulletin 17B, 28 p.

Williams, G.P., 1978, Bank-full discharge of rivers: Water Resources Research, v. 14, no. 6 , p. 1141-1154.

Wilson, T.A., 1981, Daily values duration hydrograph tables and plots (Program K956): U.S. Geological Survey WATSTORE User's Guide, v. 1, Chapter IV, Section I, $15 \mathrm{p}$. 
SUPPLEMENTAL INFORMATION 
Frequency curves for instantaneous peak flow in the James River at eight locations 






























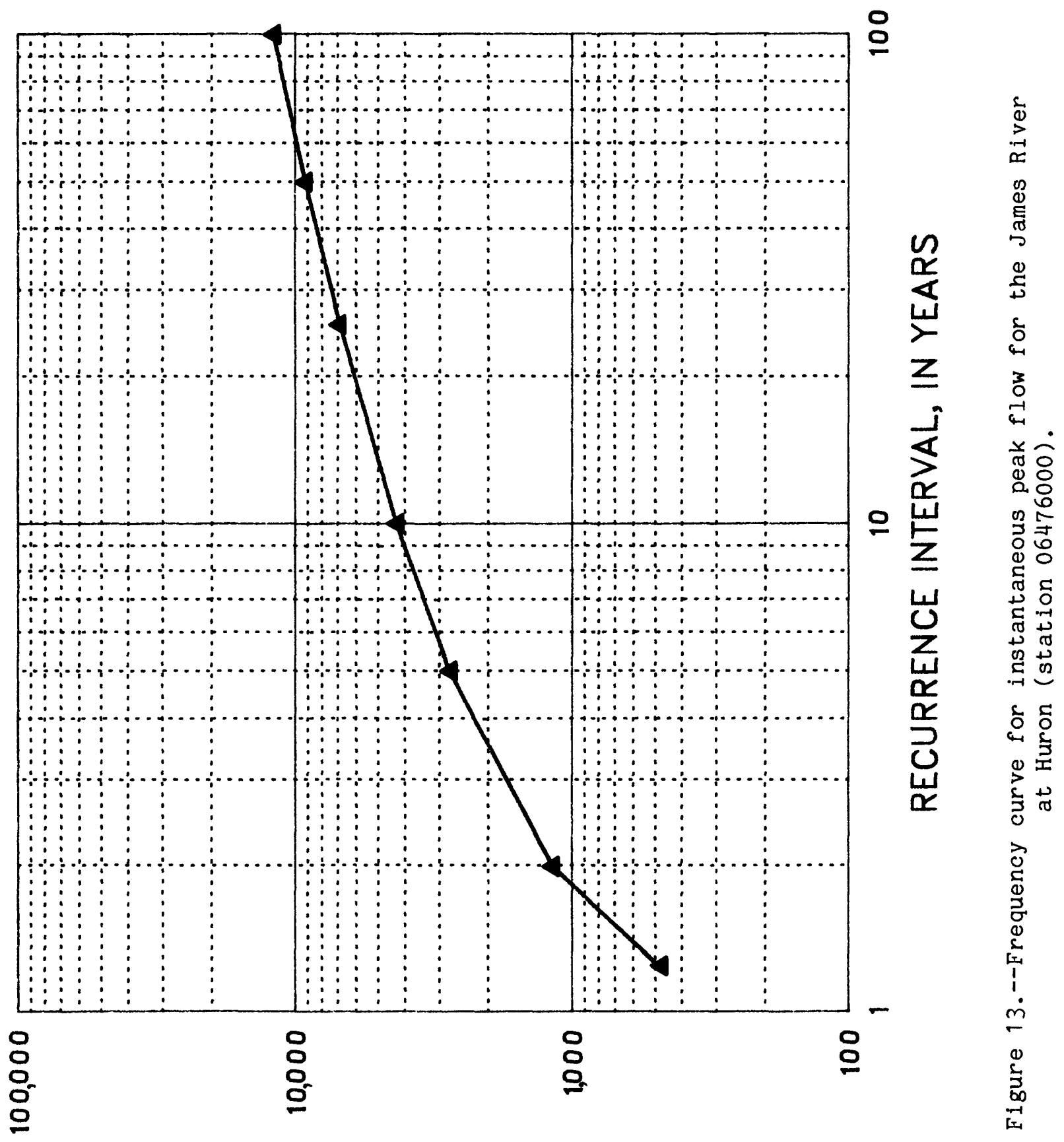

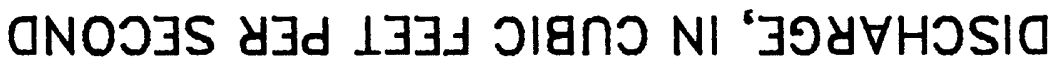




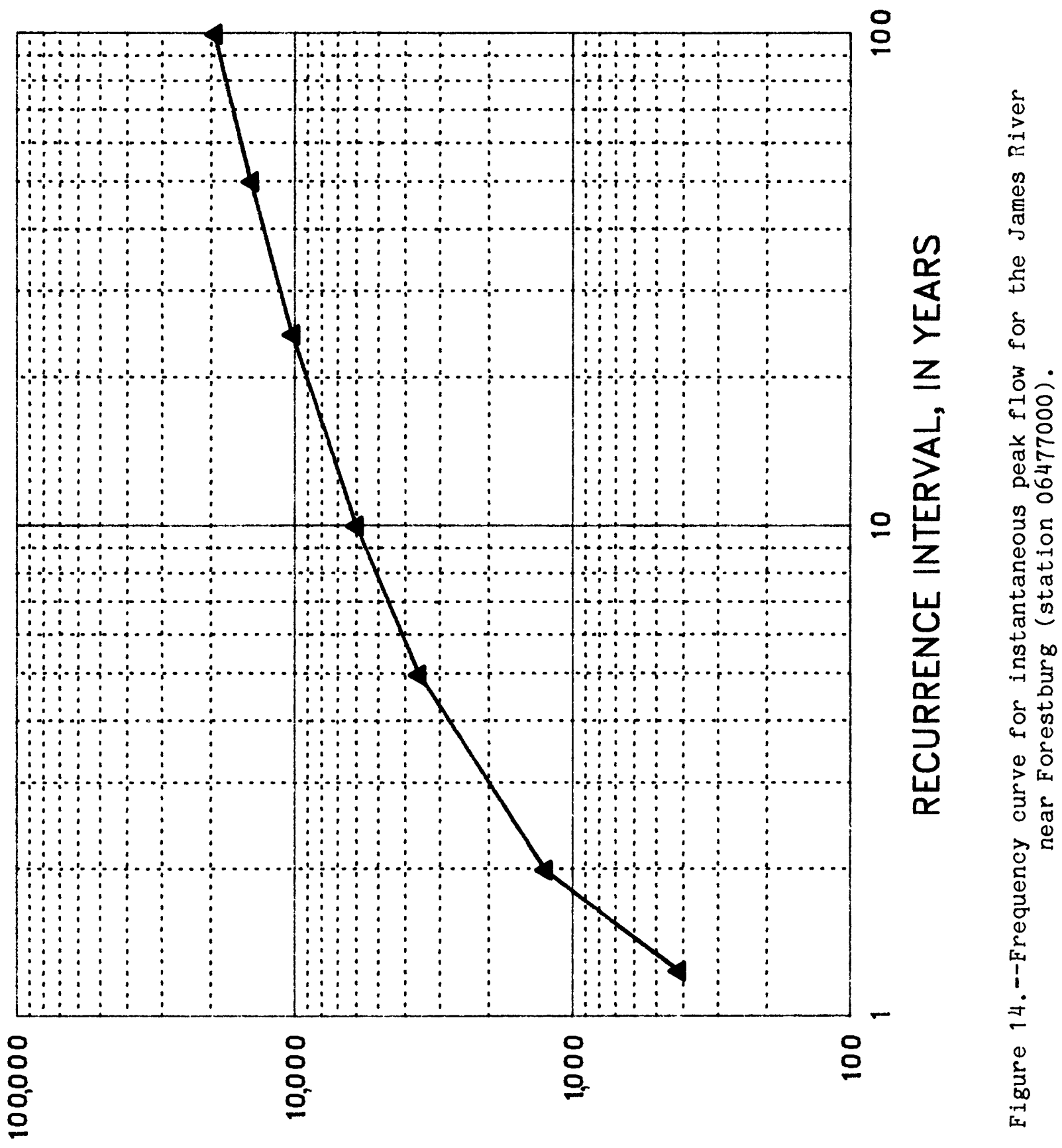

aNOJ 3 S 


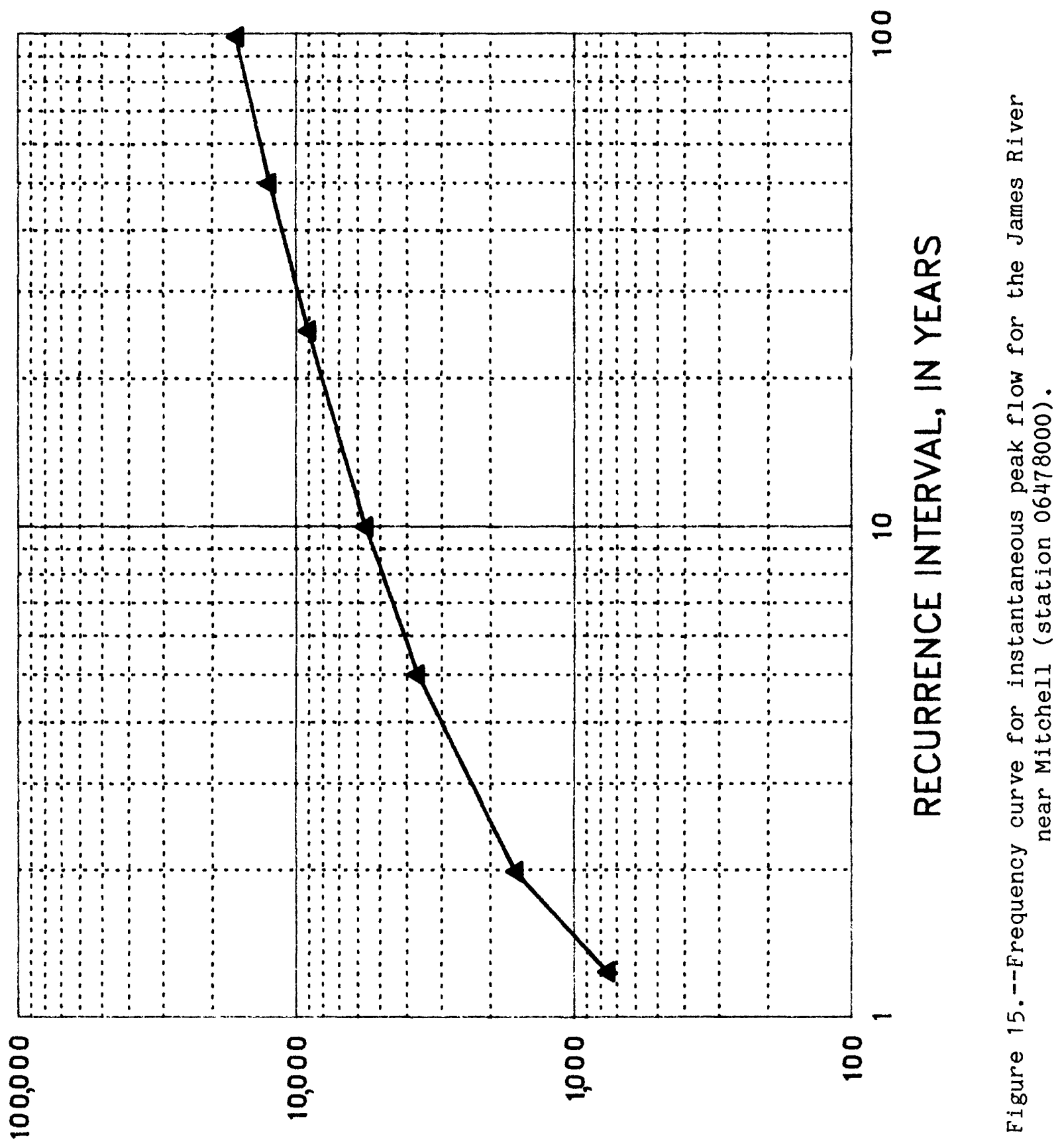

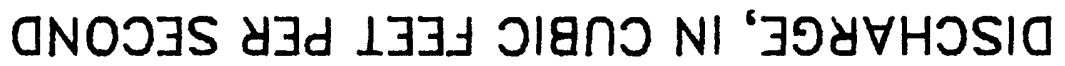




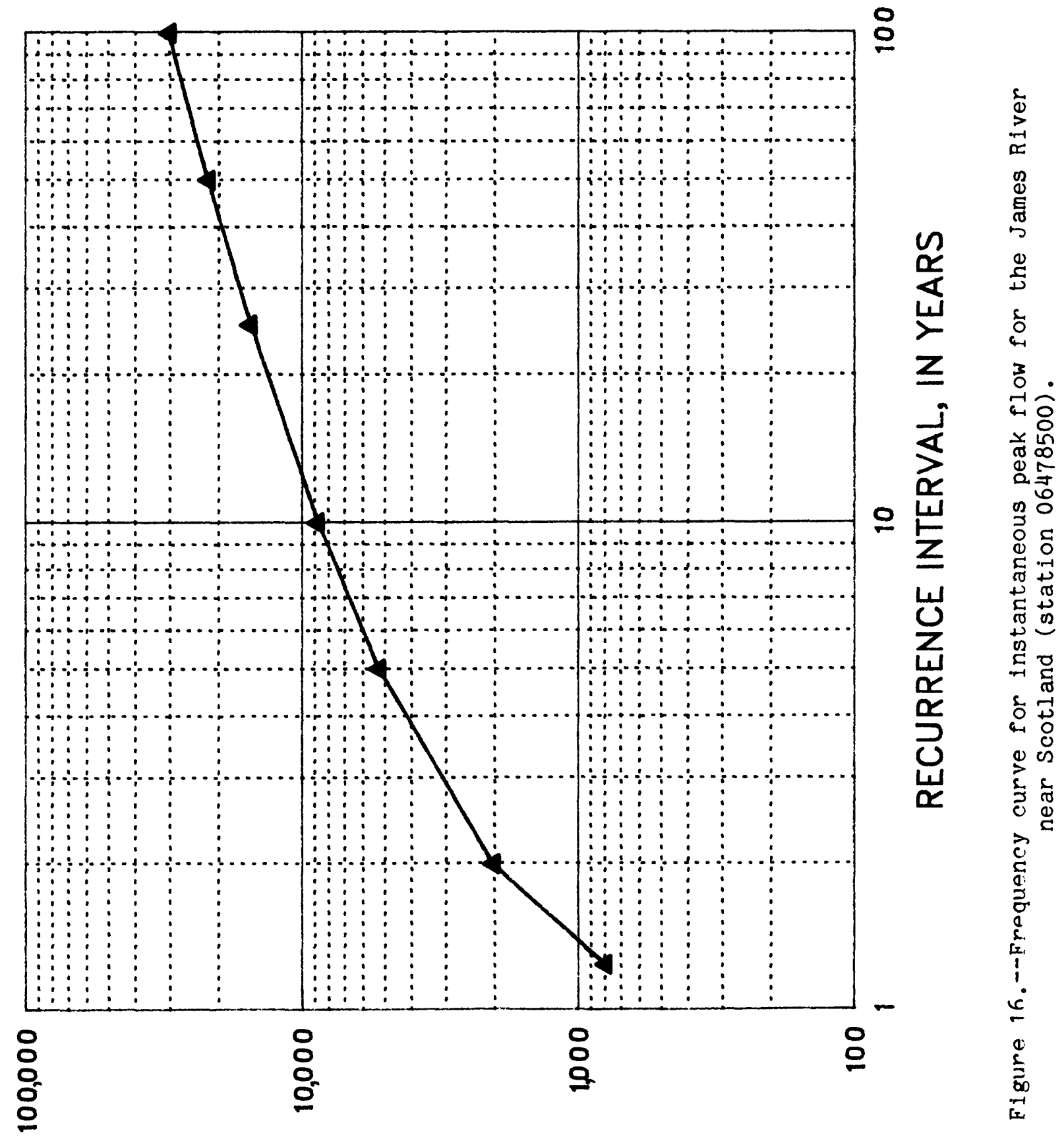

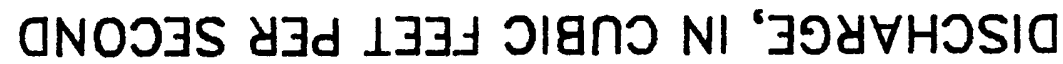


Frequency curves for maximum daily mean flow during June, July, and August in the James River at eight locations 


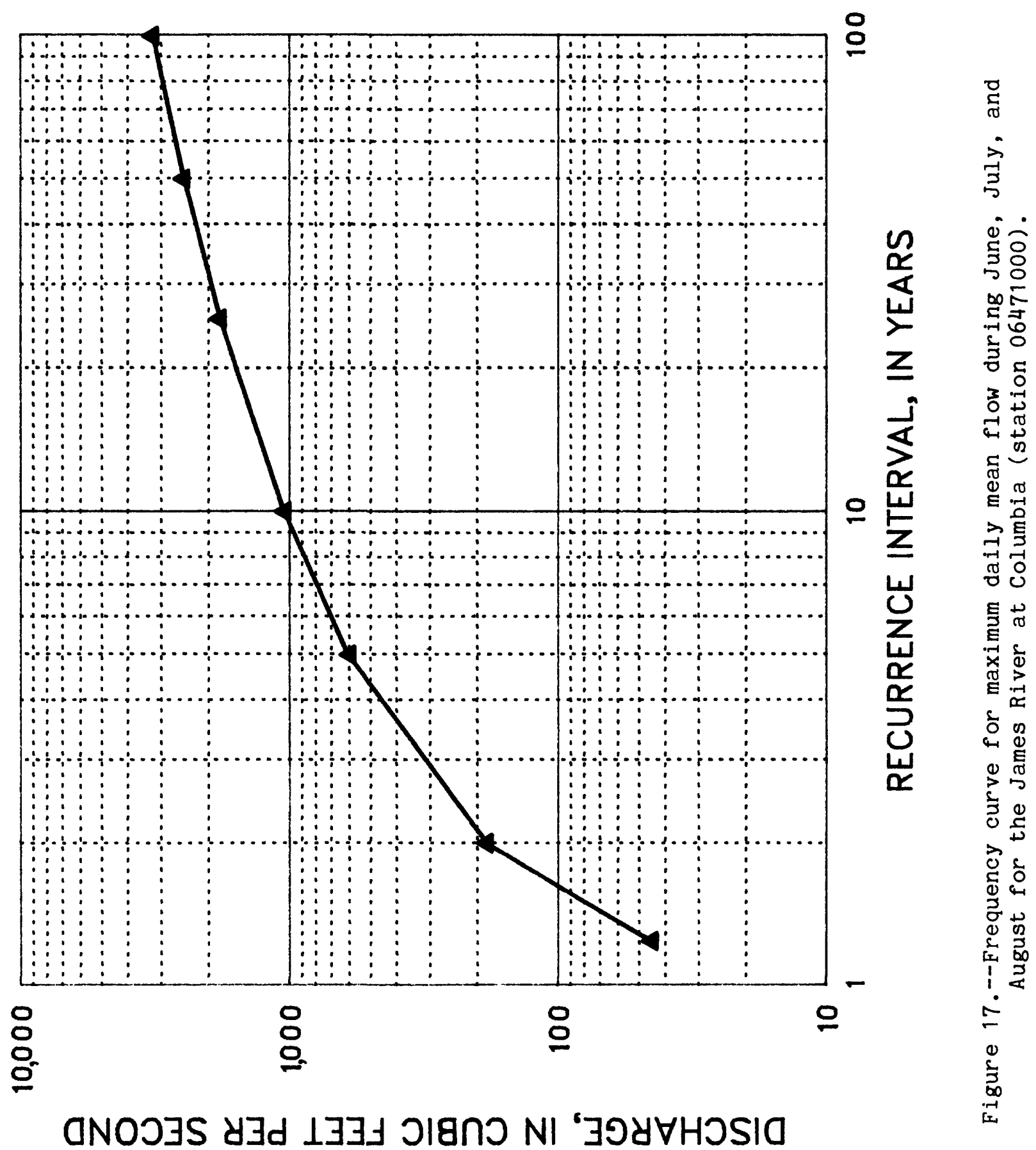




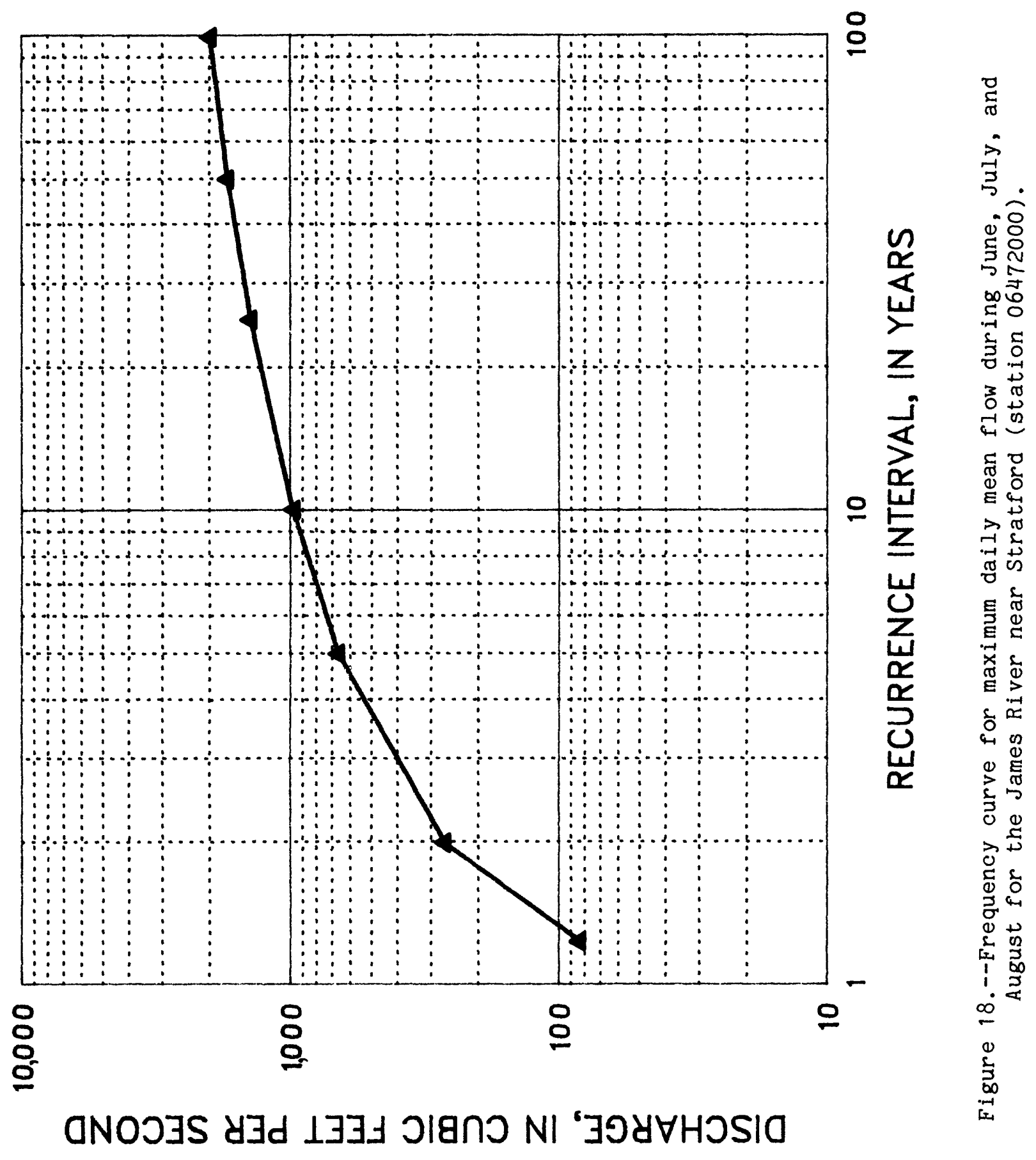




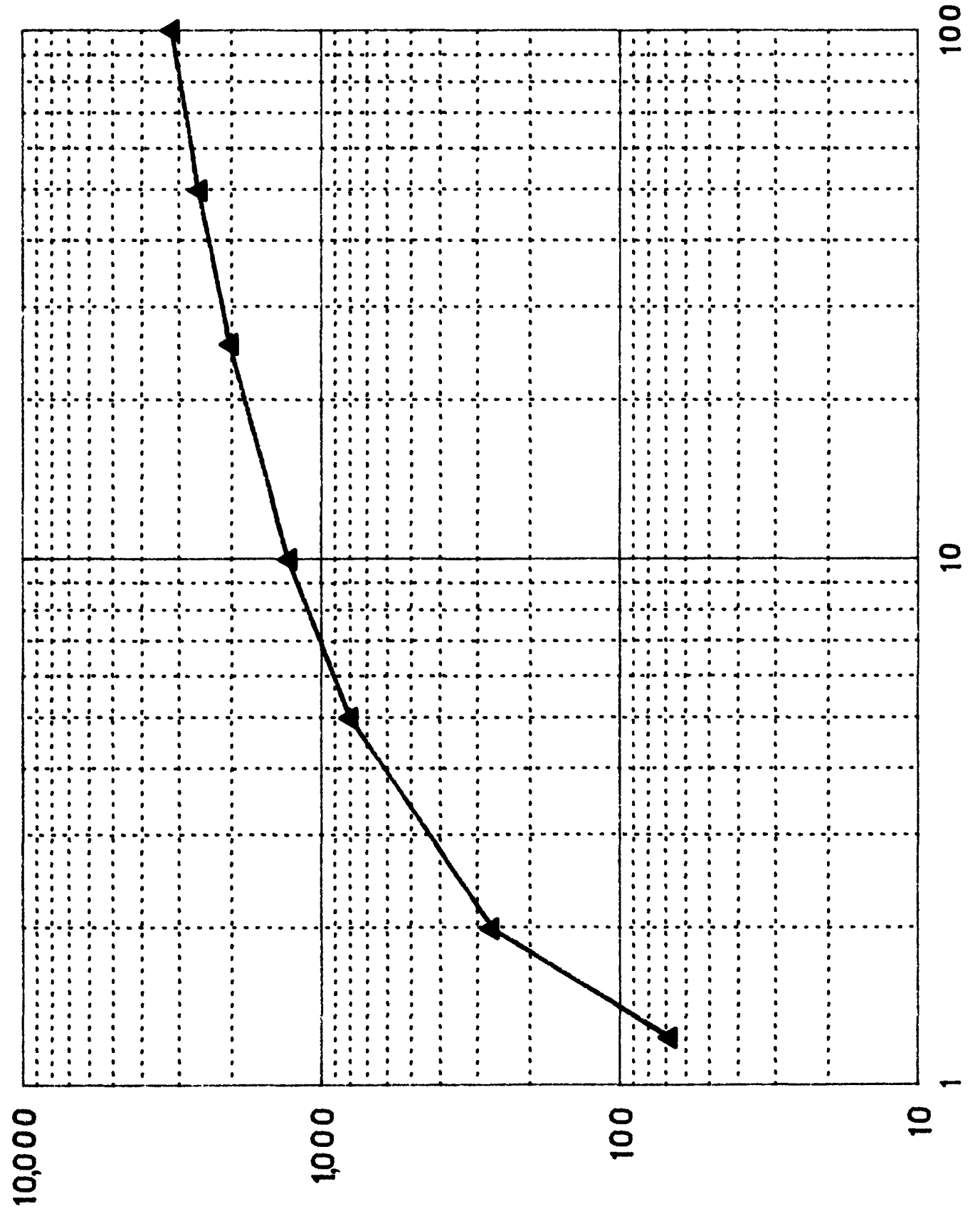

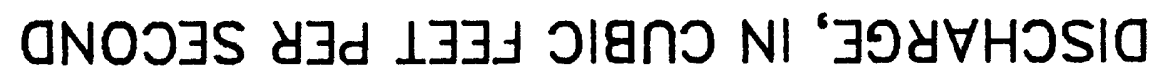

龒

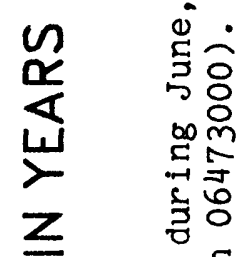

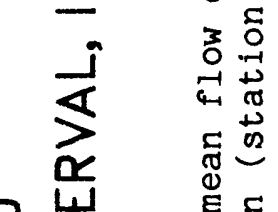

$\sum \quad \underset{j}{\rightarrow} \frac{1}{0}$

U E

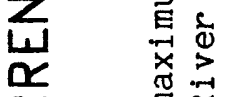

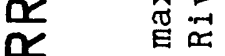

3 क

a

吉㐫

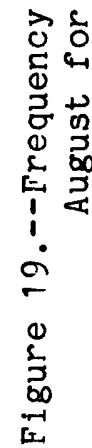




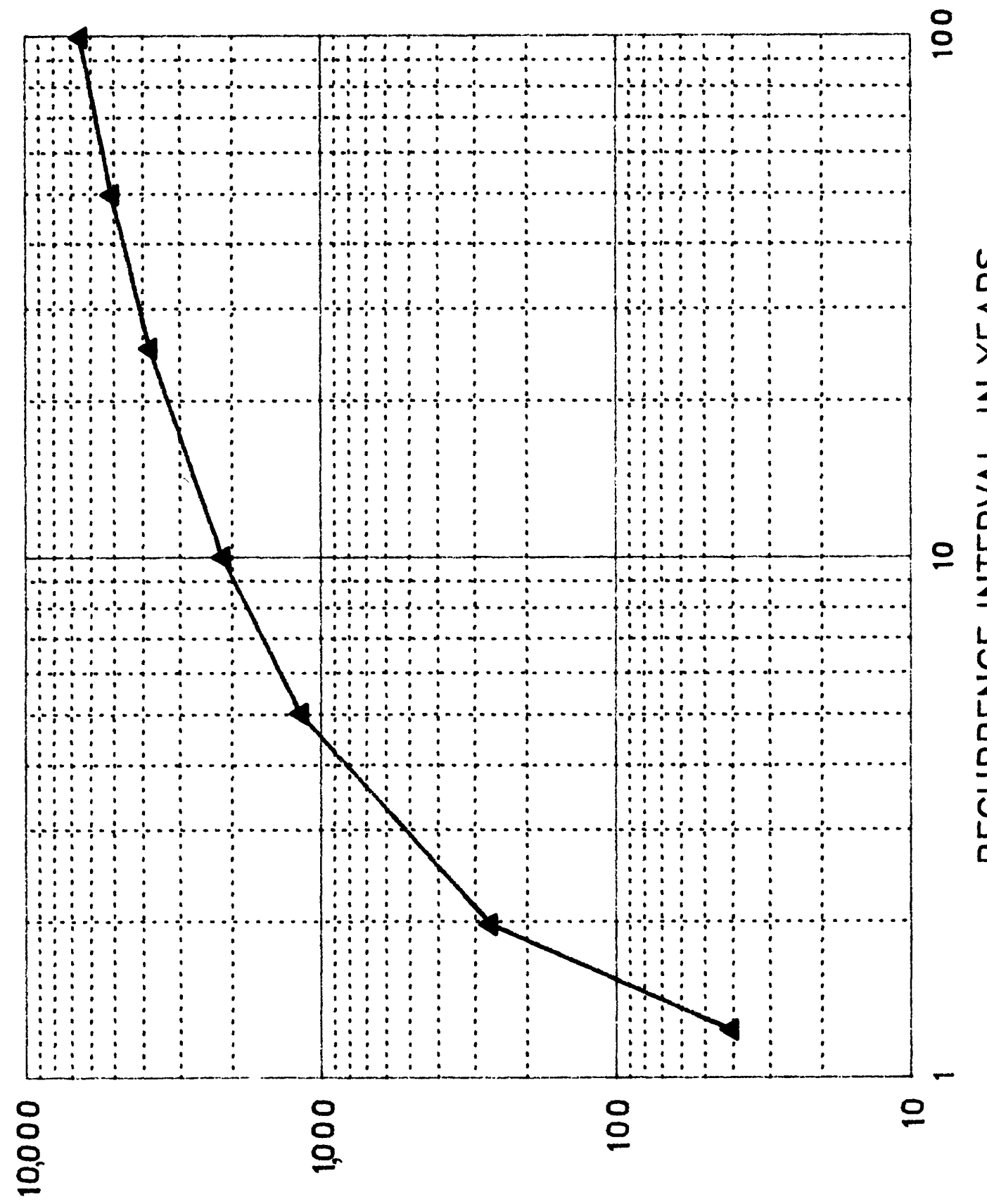

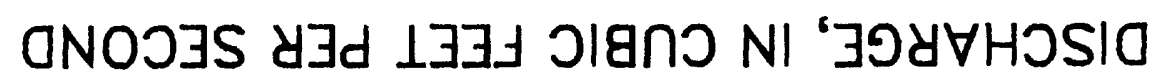




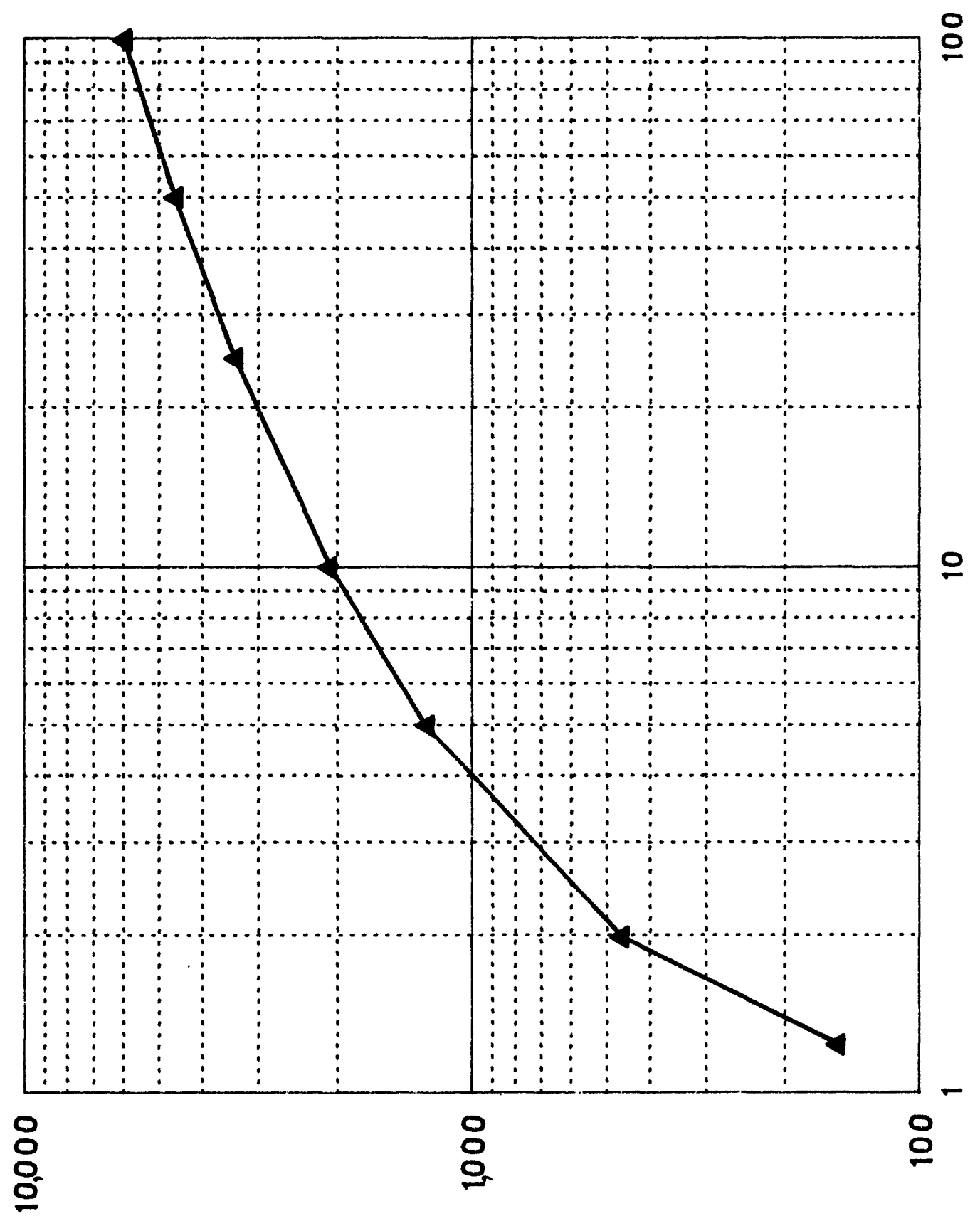

aNOJJS d 


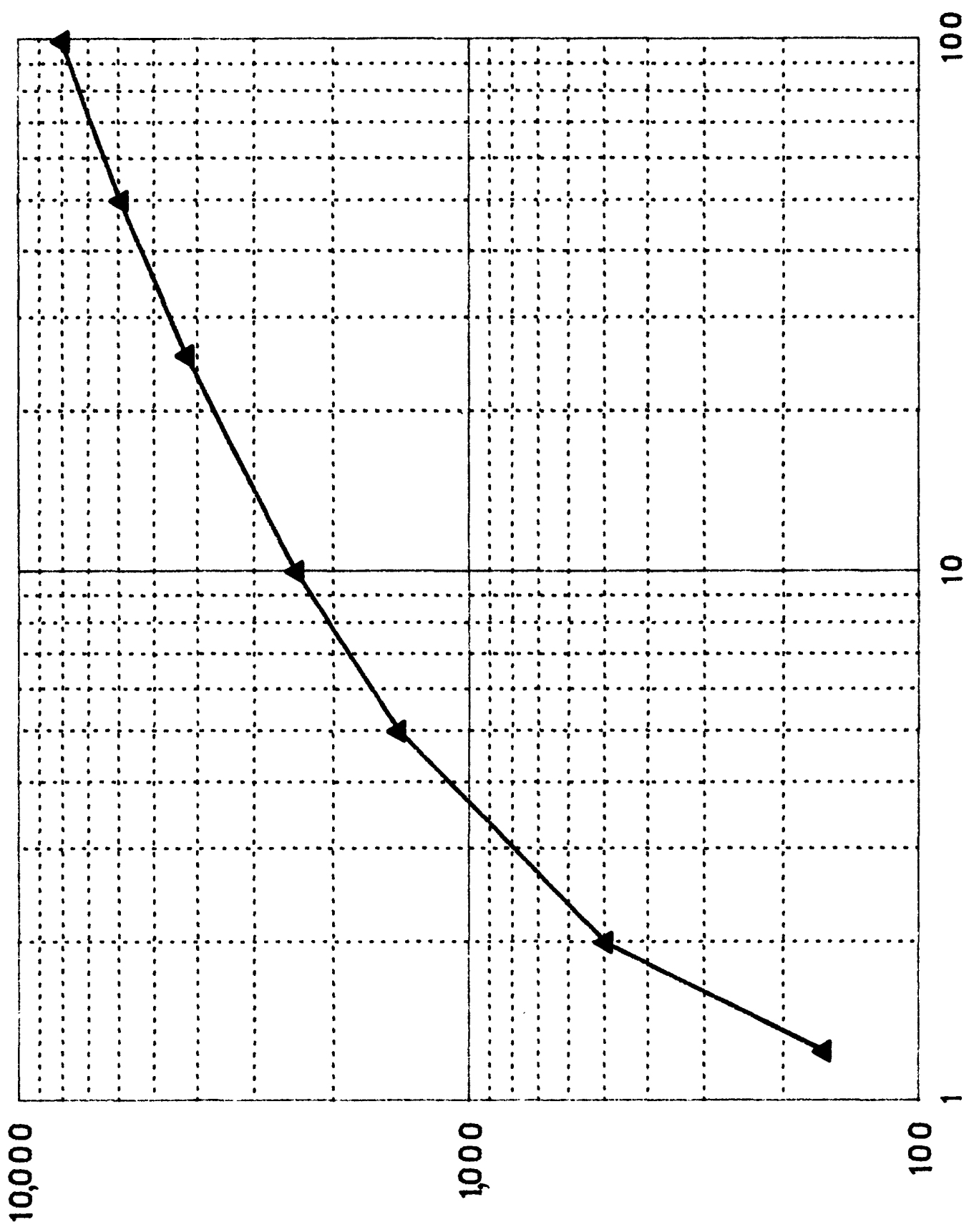

aNOJ $\mathrm{d}$ d 


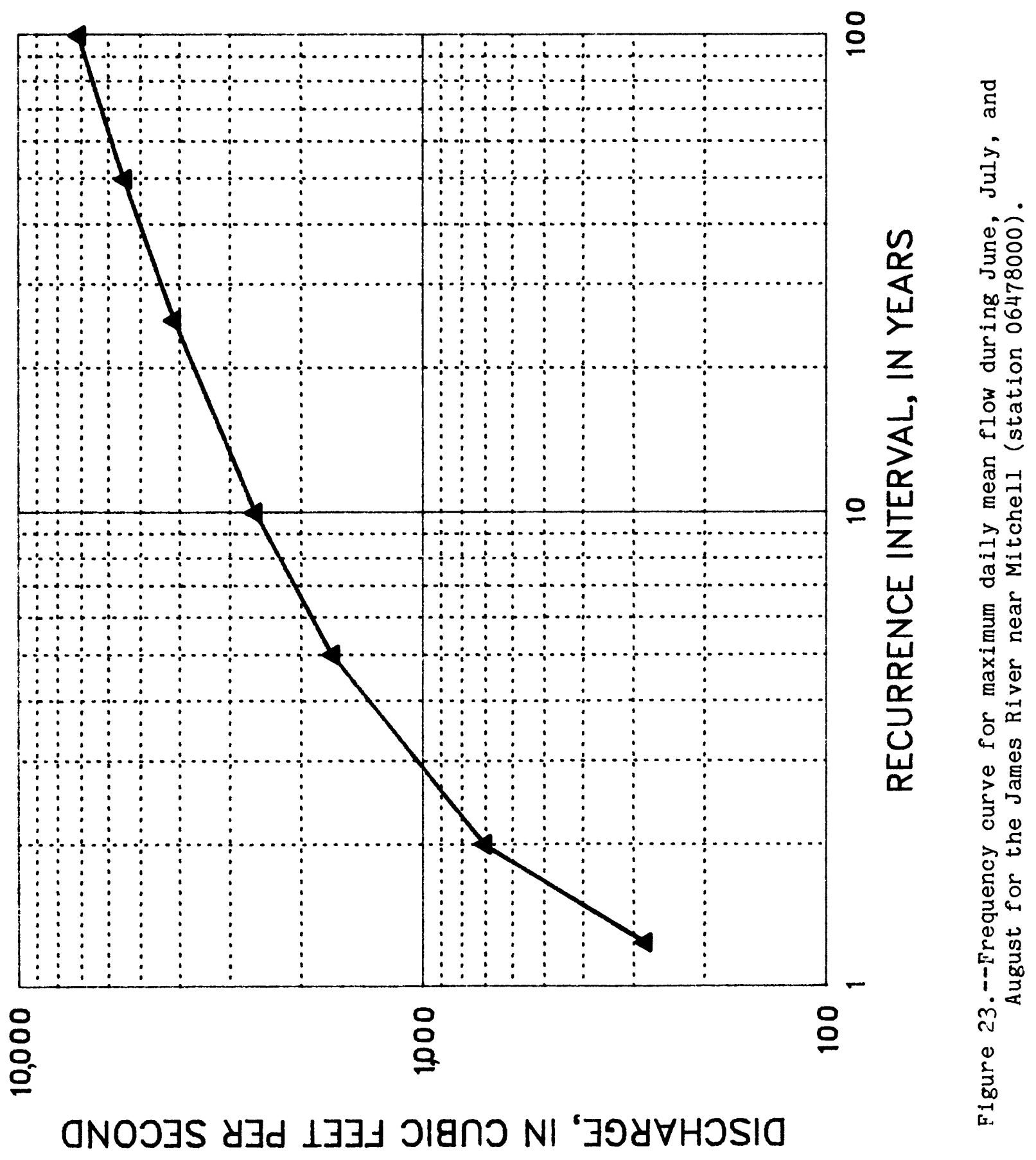




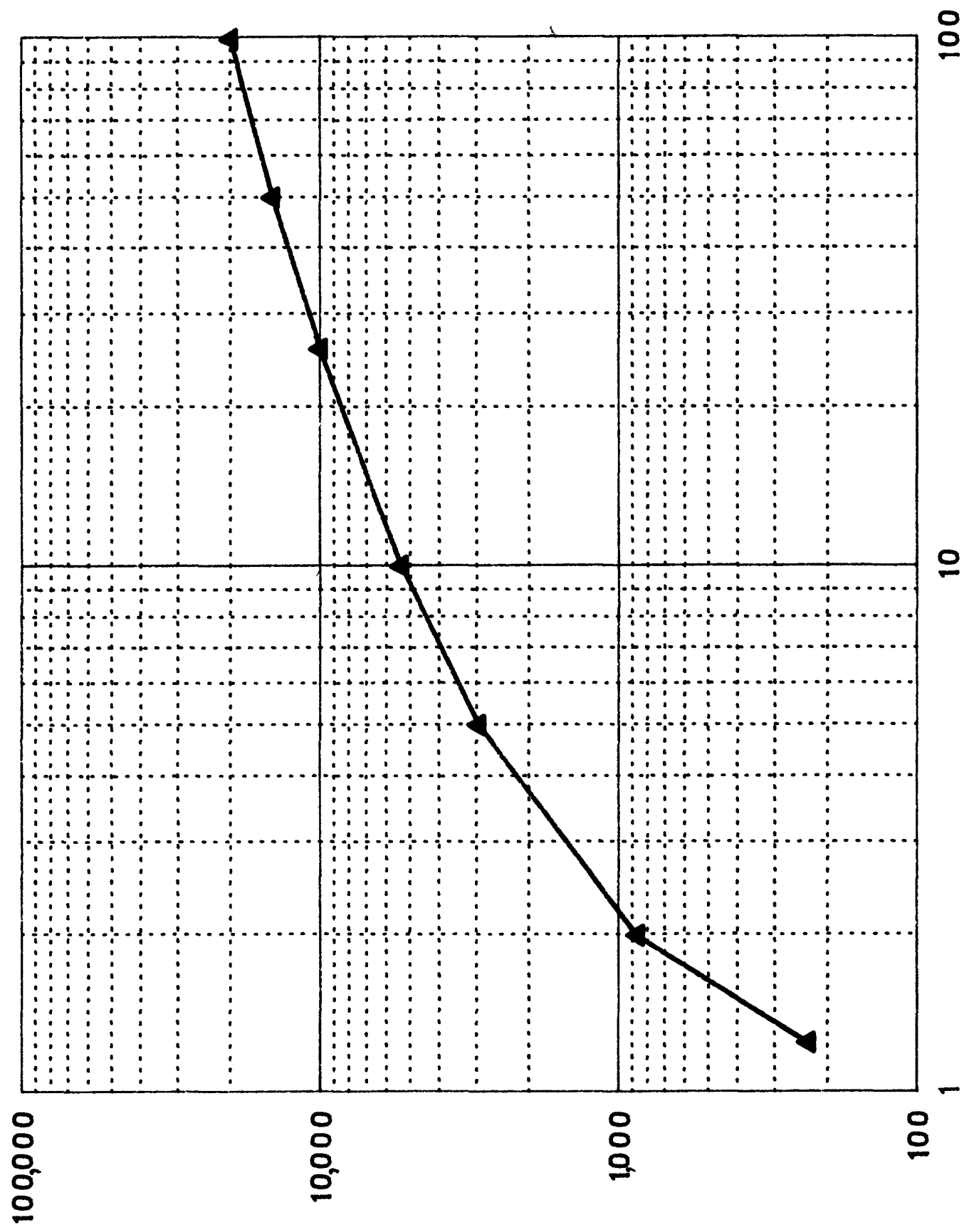

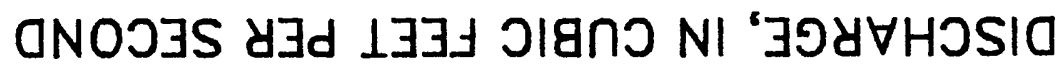


Duration hydrograph tables for the James River at seven locations 


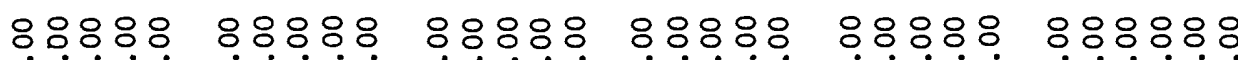

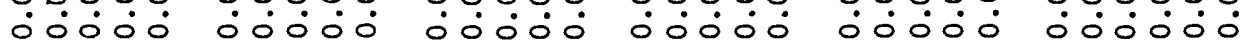

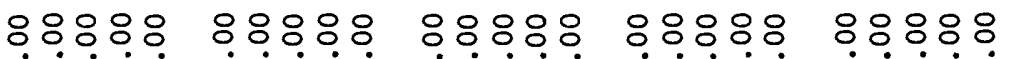
0ं0் $0 \dot{0} \dot{0} \dot{0} \dot{0} 0$ ஸं0 ¿0ं0் ஸं0் $0 \dot{0}$

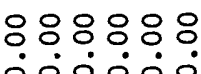

৪৪:৪০ ৪৪৪৪: ৪:৪৪৪ ৪৪:৪৪ 0ं0்: 0ं0்: 0ं0் 웅요

::8:: ஸ்:

৪৪:৪৪: 0ं0் $0 \dot{0}$

৪৪:৪: ৪:৪৪:

৪৪৪৪

৪৪:০

৪:৪: :

$8: 888:$ 0ं0்: 0ं0்: 0.00. ०0.0. 0ं0்: 0ं0்0ं

৪৪৪৪৪ ৪৪৪৪০ ৪৪৪৪৪ ৪৪৪৪৪ 뭉ㅇ $\dot{0} \dot{0} 0 \dot{0}$ ல0்0் 0ं0்:

৪:০০:

응용ㅇㅇㅇㅇㅇ

옴유유유. 운요요요



유:

ஸे

$8: 88: 8$ mivi-

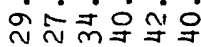

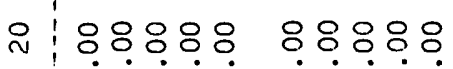



\section{웅유}

웅ํㅇㅇํㅇ

$8: 808$

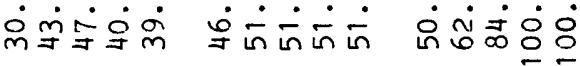

요:8:



8:8:

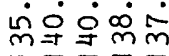

용요

웅ㅇㅇㅇ

우웅

웅ㅇㅇ ம்ம்ம்

৪৪8:8:



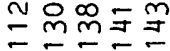
ำ่ำm

m느ㄴㅛㅡ



88888

88888

$8080 \div$



$8: 8: 8$

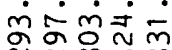

888888

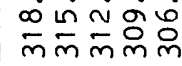

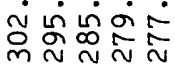




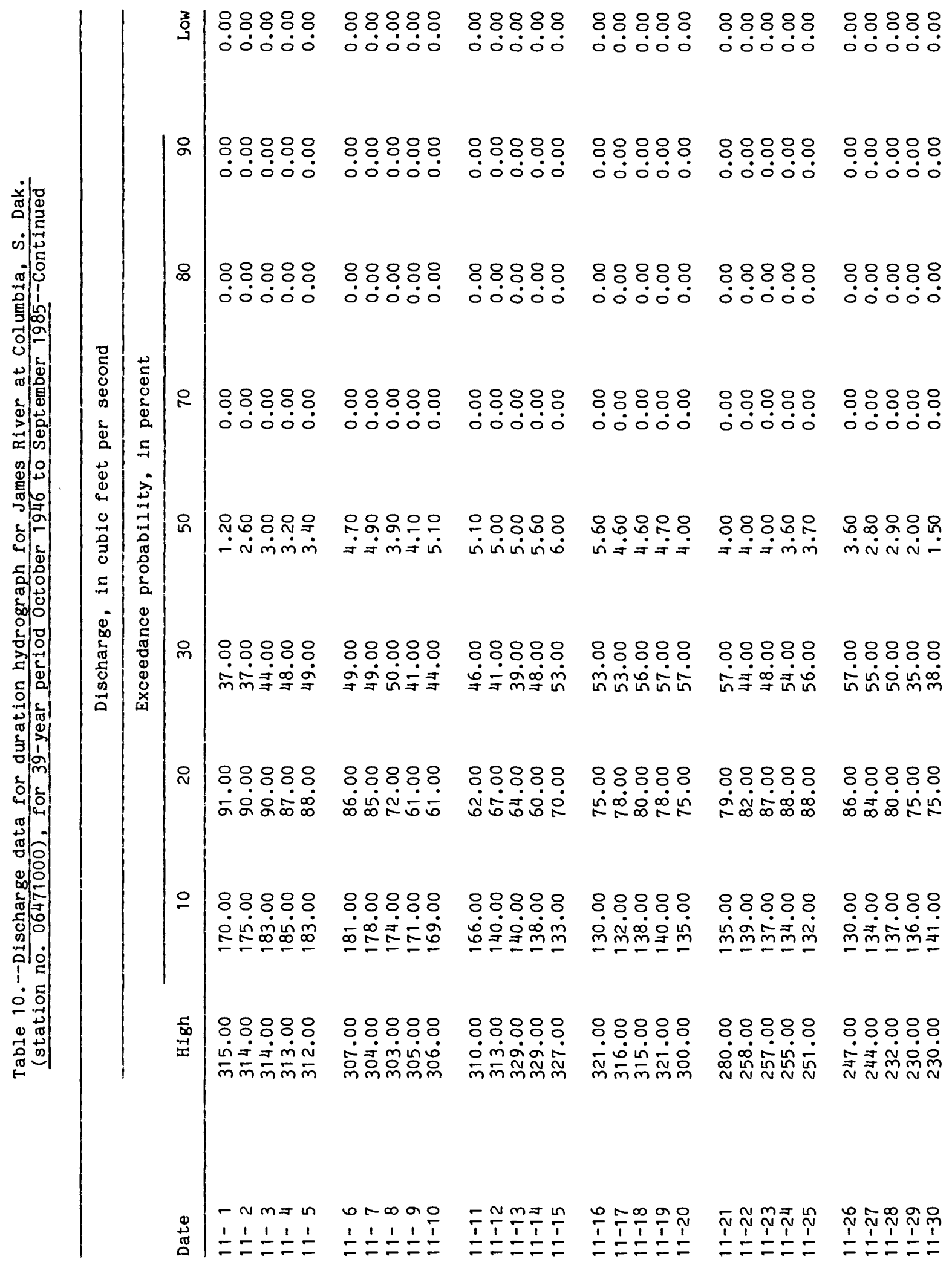




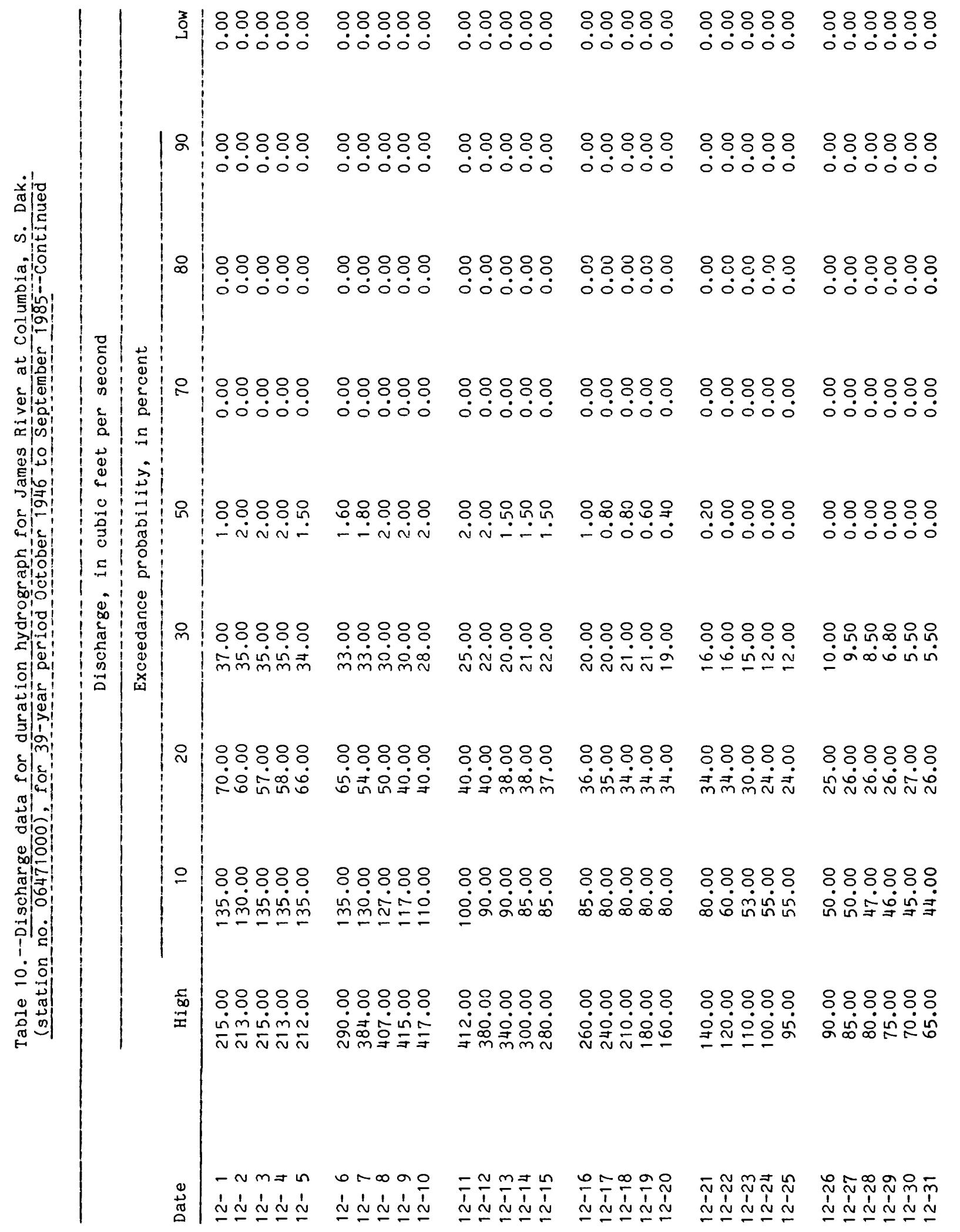




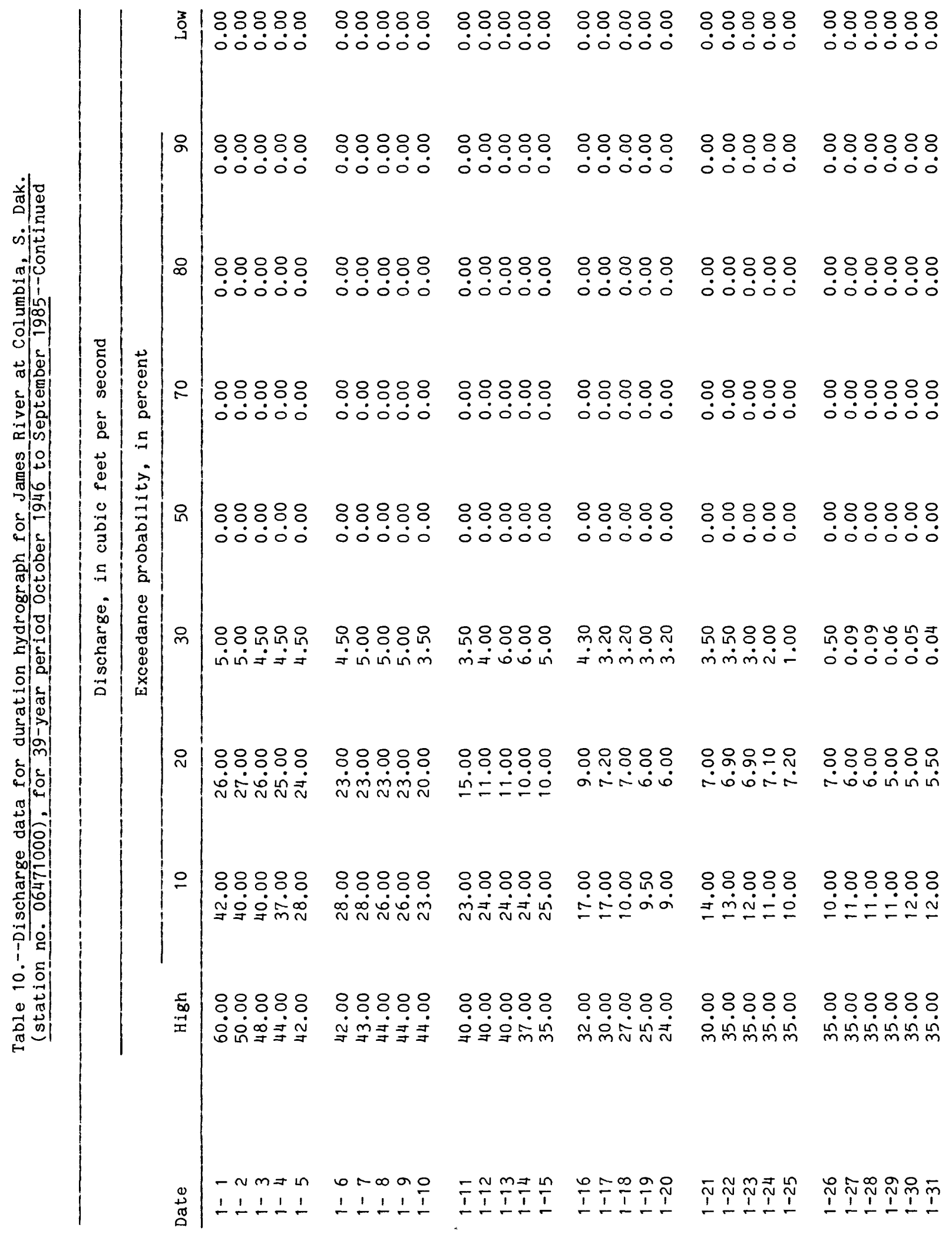




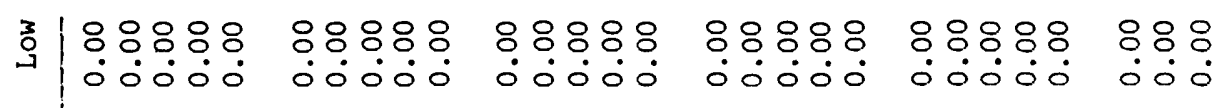

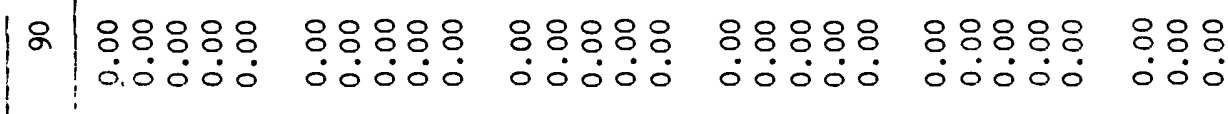

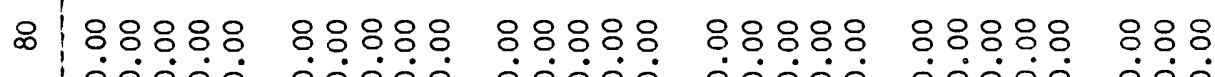
00000 00000 00000 00000 00000 000

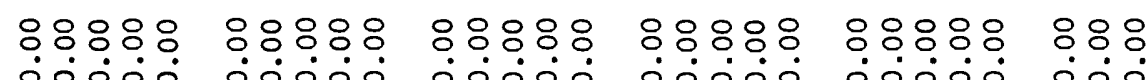

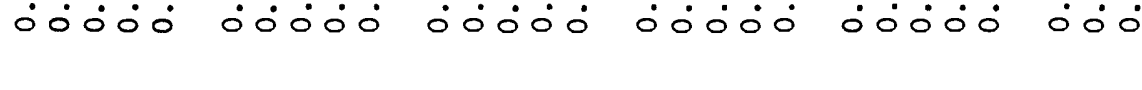

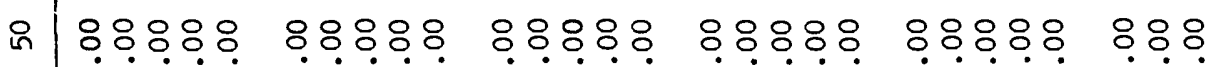

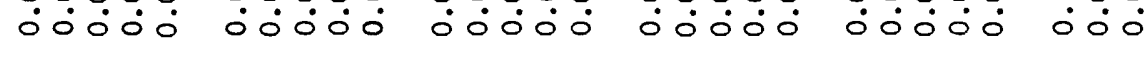

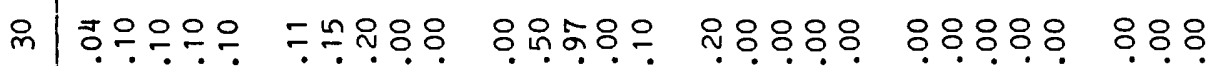

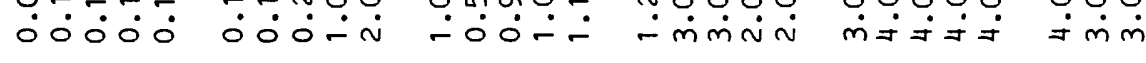

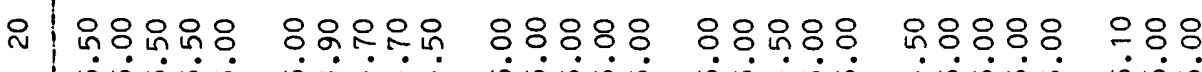
ம்

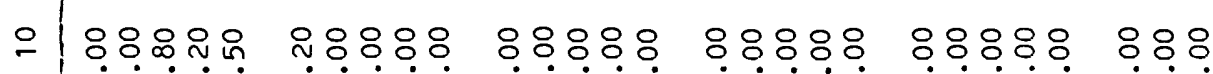
=에o

다

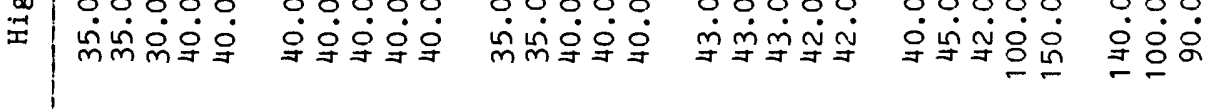

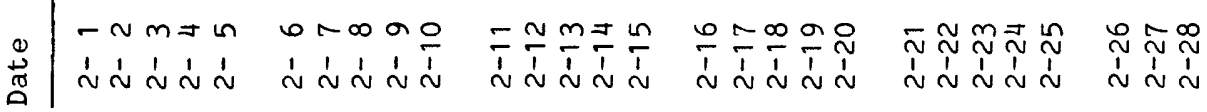




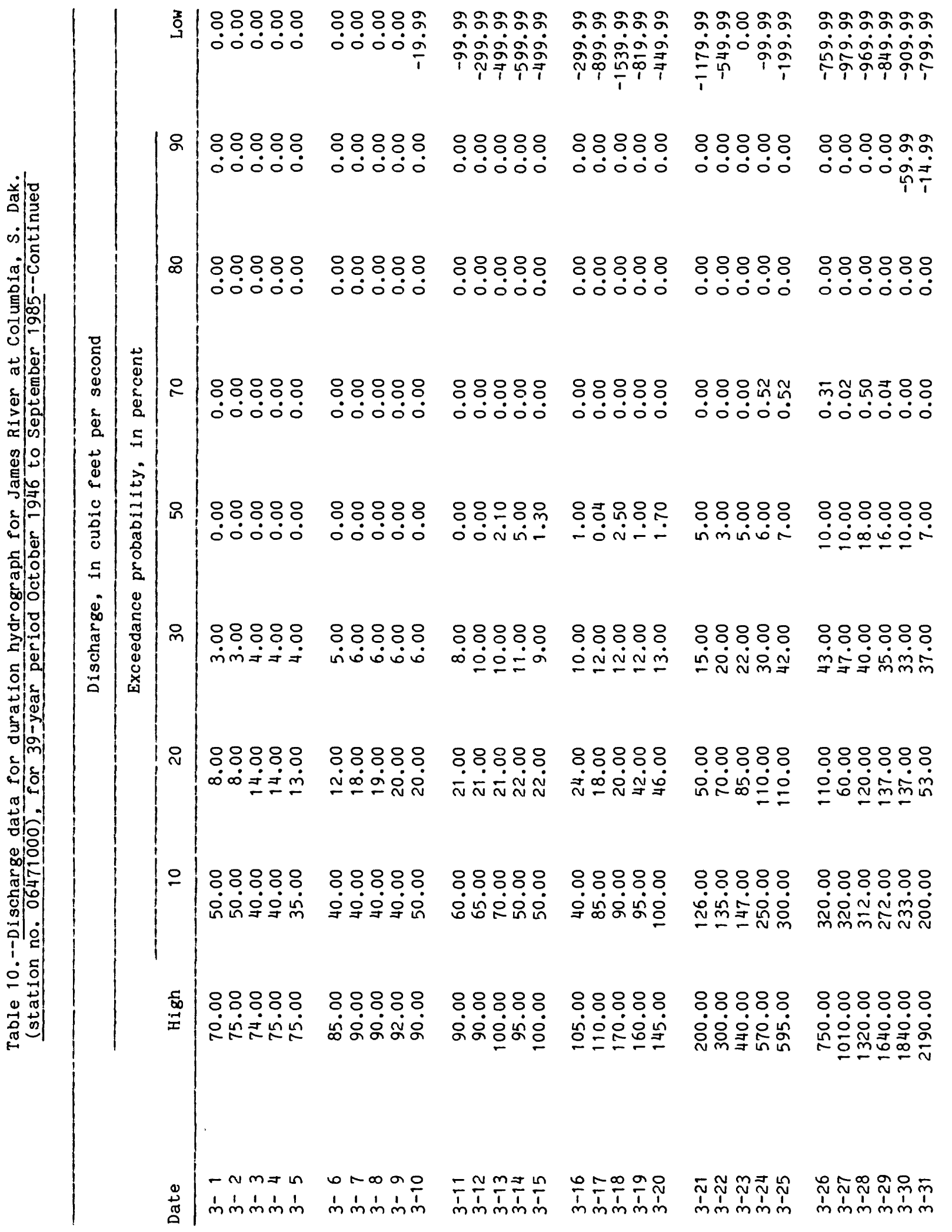




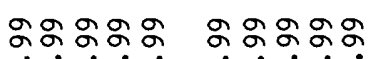

영ㅇㅇ 의의

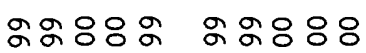

Иิ영영

รूं



कें



ภู

जि

눈눈

으ำรㅇำ

ㅇํㅇํํ․

80800
00000

$8: 8 \%$

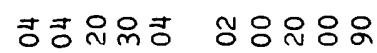

अंवेंक्षे क००

0ं0웅

०000.

0웅

৪৪:০০

웅ㅇㅇㅇㅛ

옹융요요

음웅윰유

용ㅇㅇ 웅요웅 웅응

00000

무

$\dot{m} \div \dot{\sim} \dot{\sim}$

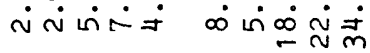

응유응ㅇ 옹ㅇㅇ우유

영-

-ing்

용ㅇㅇㅇㅛ

용ㅇ

ㅇ:ㅇ 용요

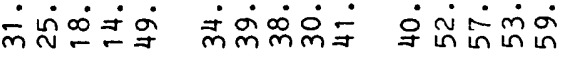

in

우늉ㅇㅇㅇ 웅우웅

过完绾官

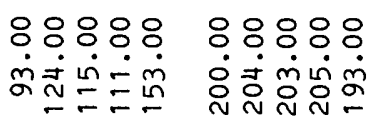

8:용

$8: 8: 8$

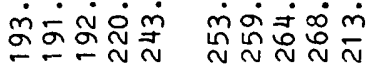

요

ผี்่ٔ $\dot{8} 8$

$\circ: \circ \circ \circ$



$8: 8: \circ$

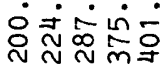

:৪:০:

ஸ்ற்ற்



$8: 8: 8$

ठㅎํ세요

$8: 88:$



ஃㅇㅇ ㅇ๐ㅇㅇ

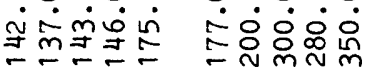

용ㅇ

ळi

우웅

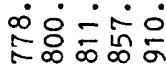

:৪8:

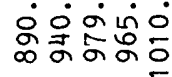

৪:웅

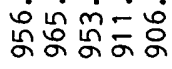

응

$8: 8: \circ$

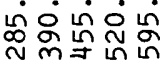

৪:ㅇㅇ

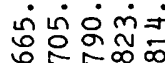

$8: 80 \%$

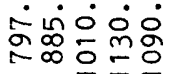

용요

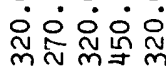

$8: 808$

형ㅇㅇ

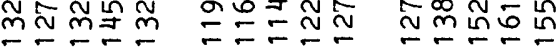

$8: 8: 8$

형ㅇํ

ㅇํㅇํㅇ



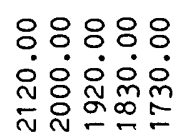

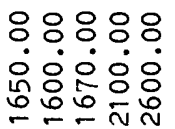
웅유 і்ㅎ்요

웅ํำ 웜융영

우웅 i்

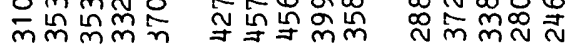

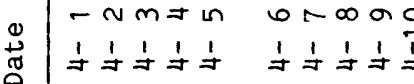

$=\simeq m \pm n$

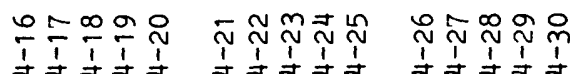









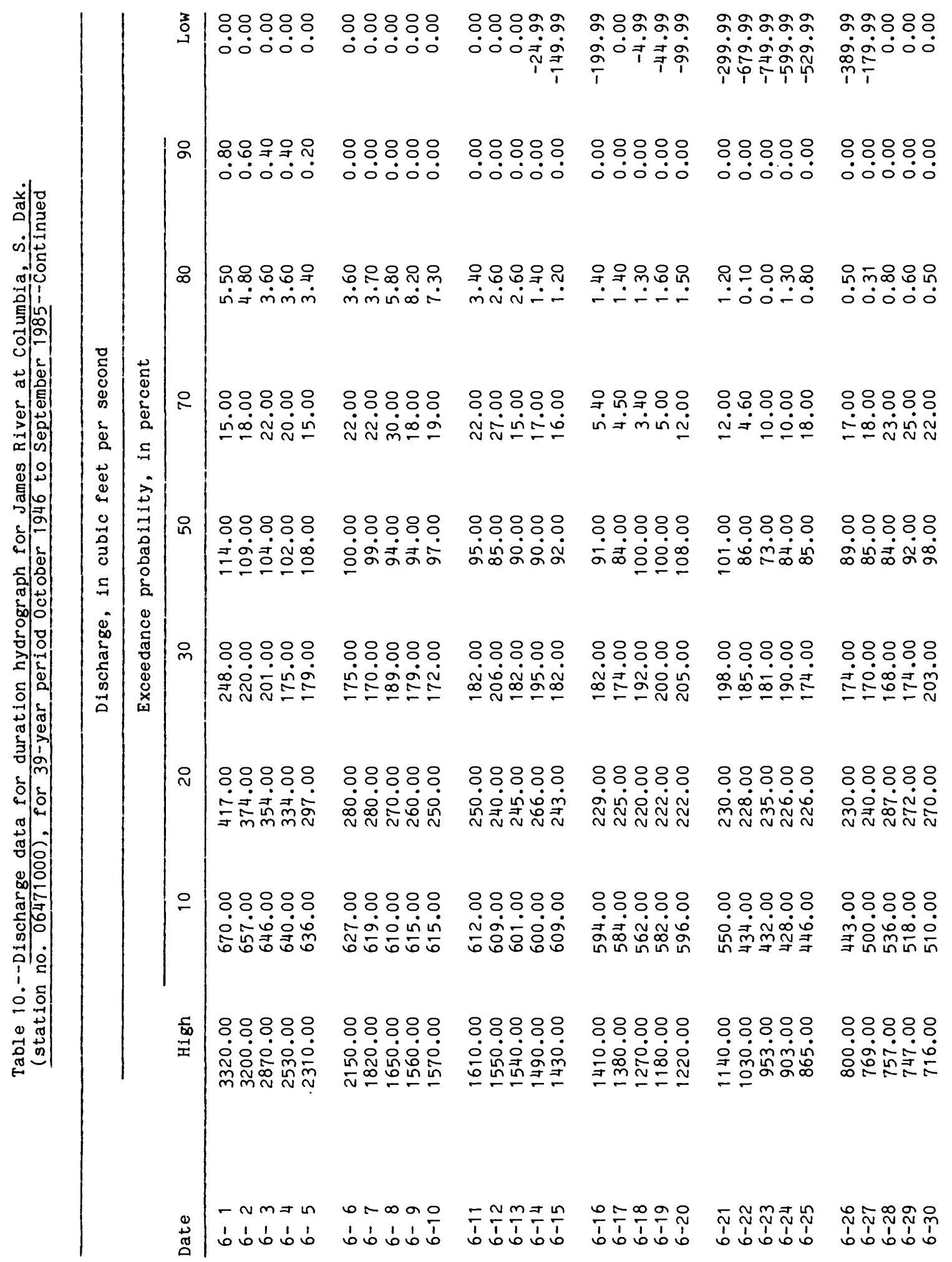




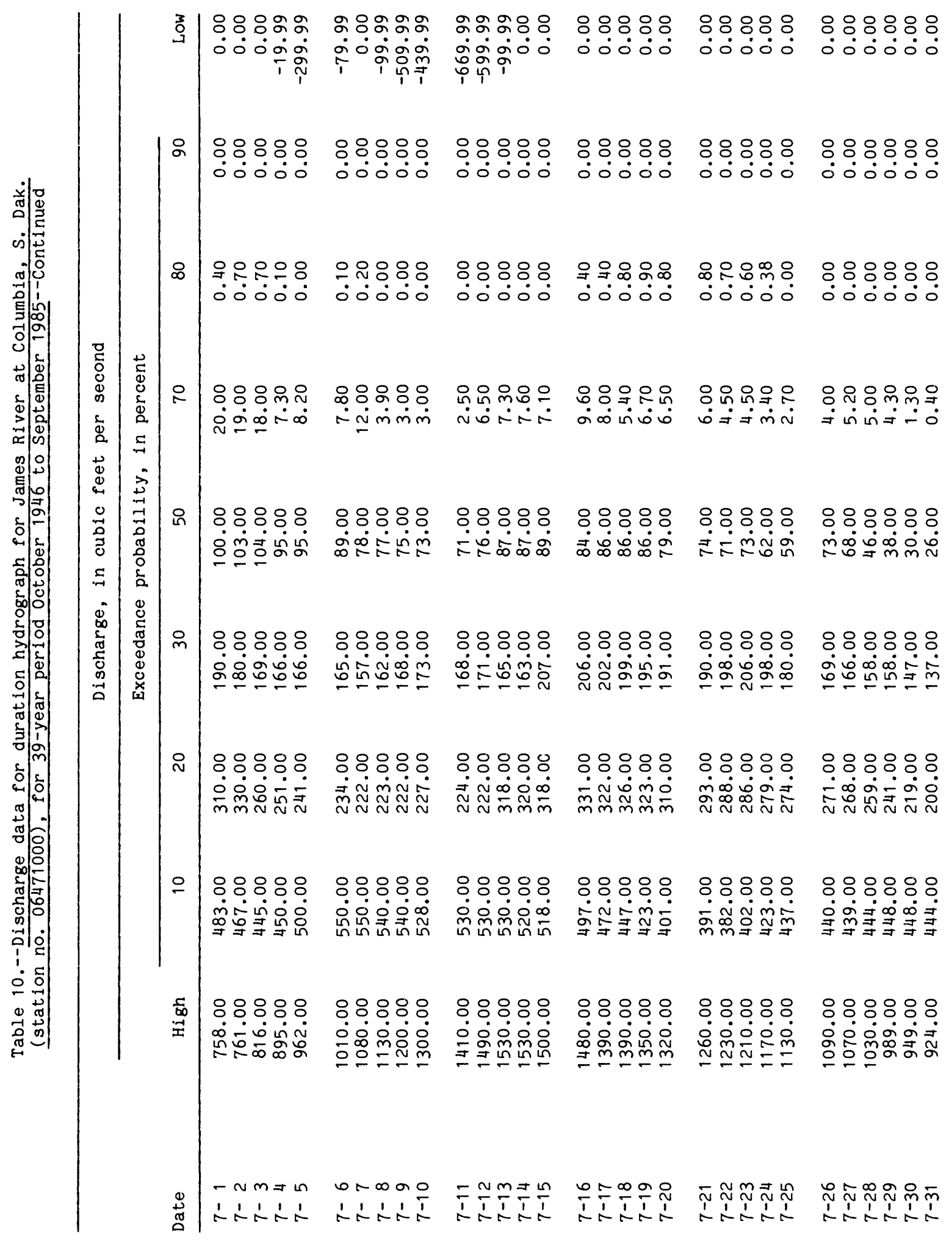




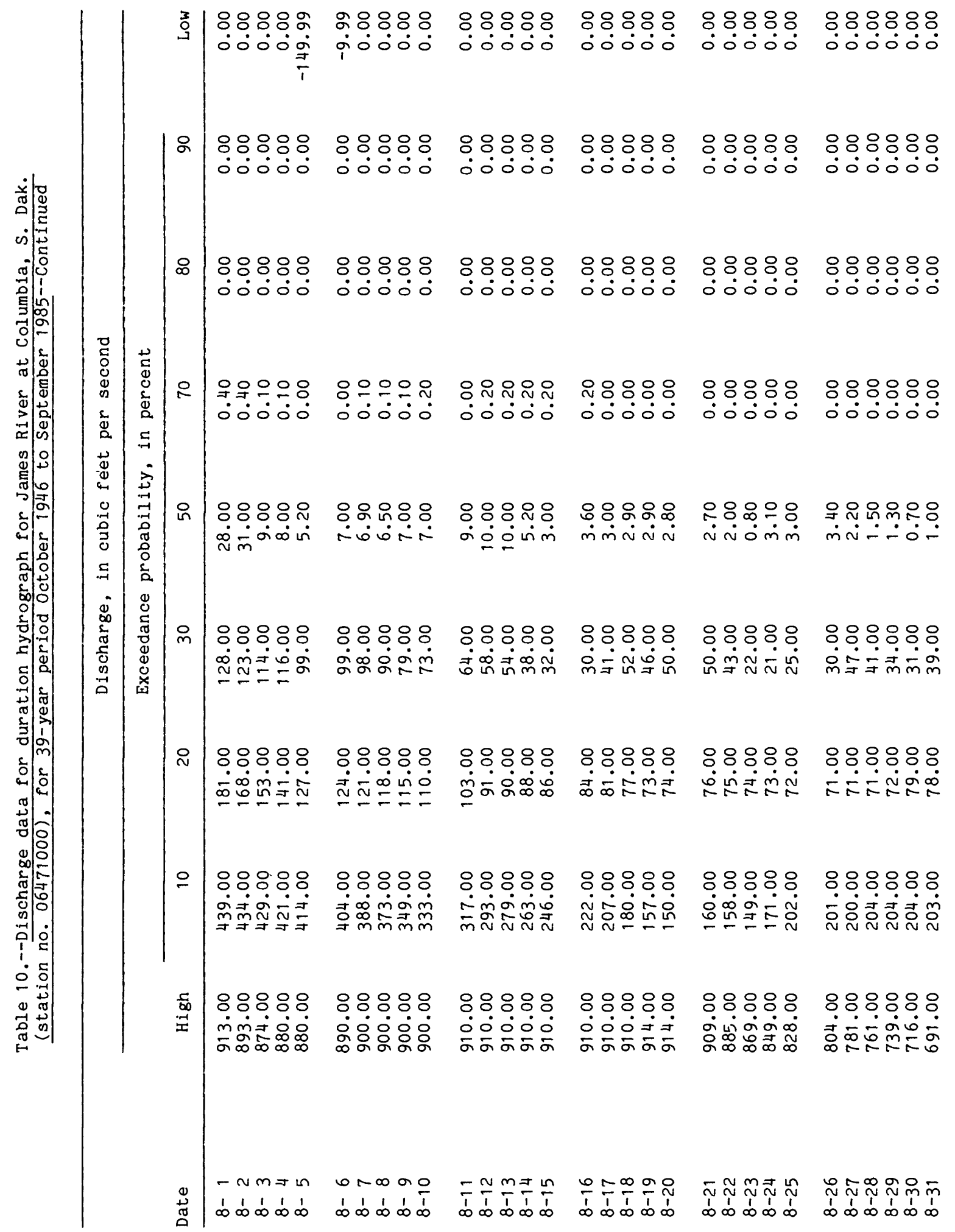




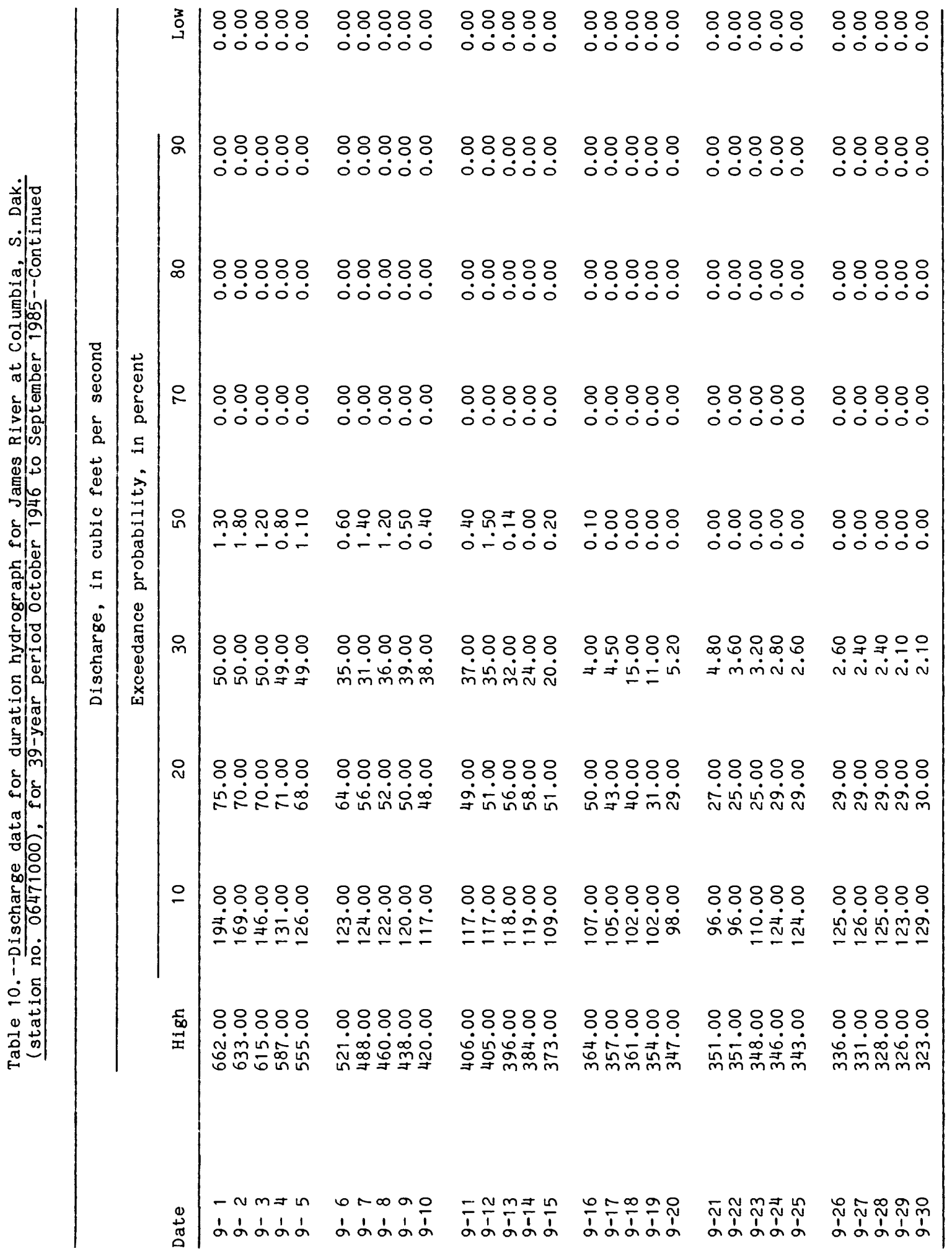
























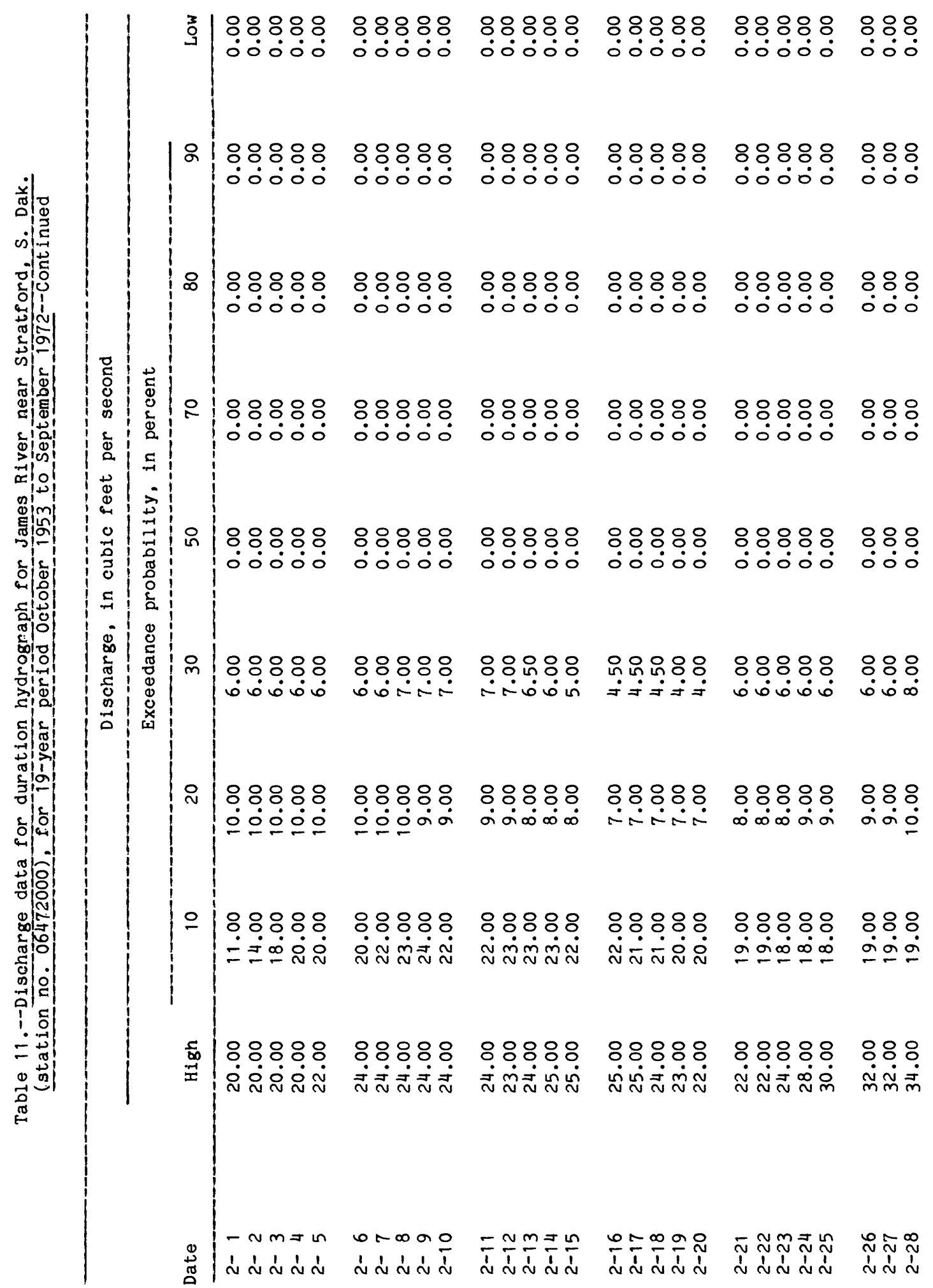




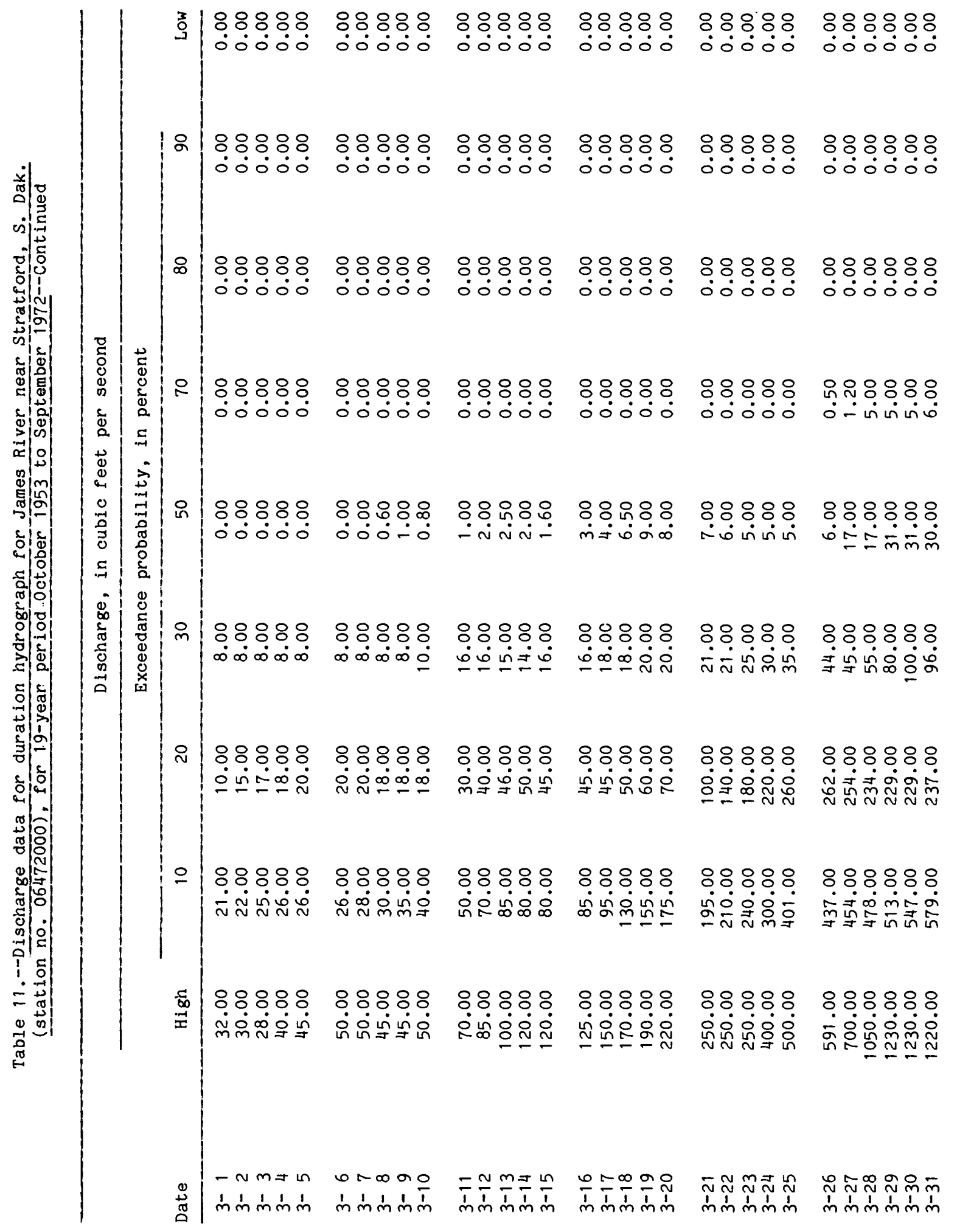









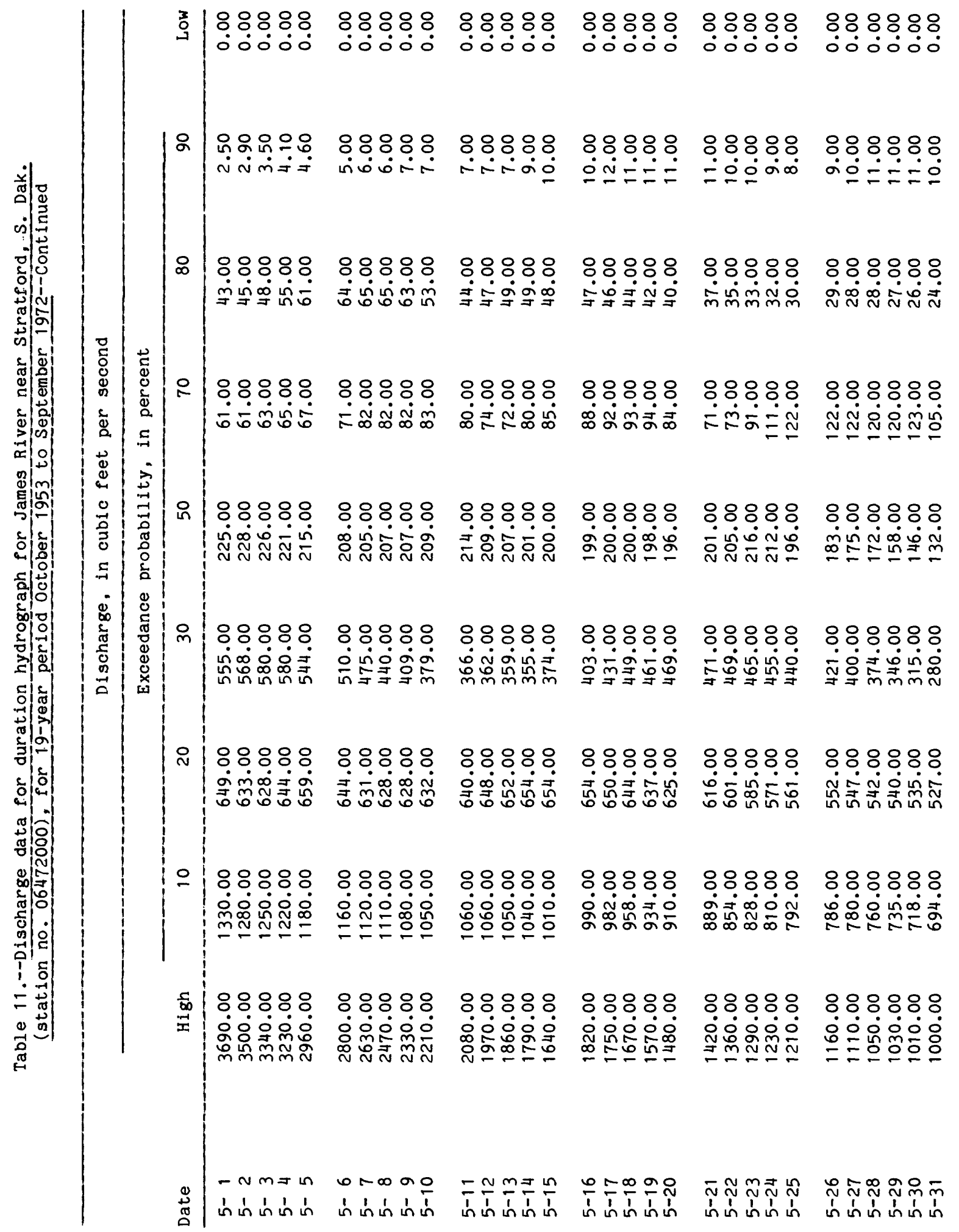



















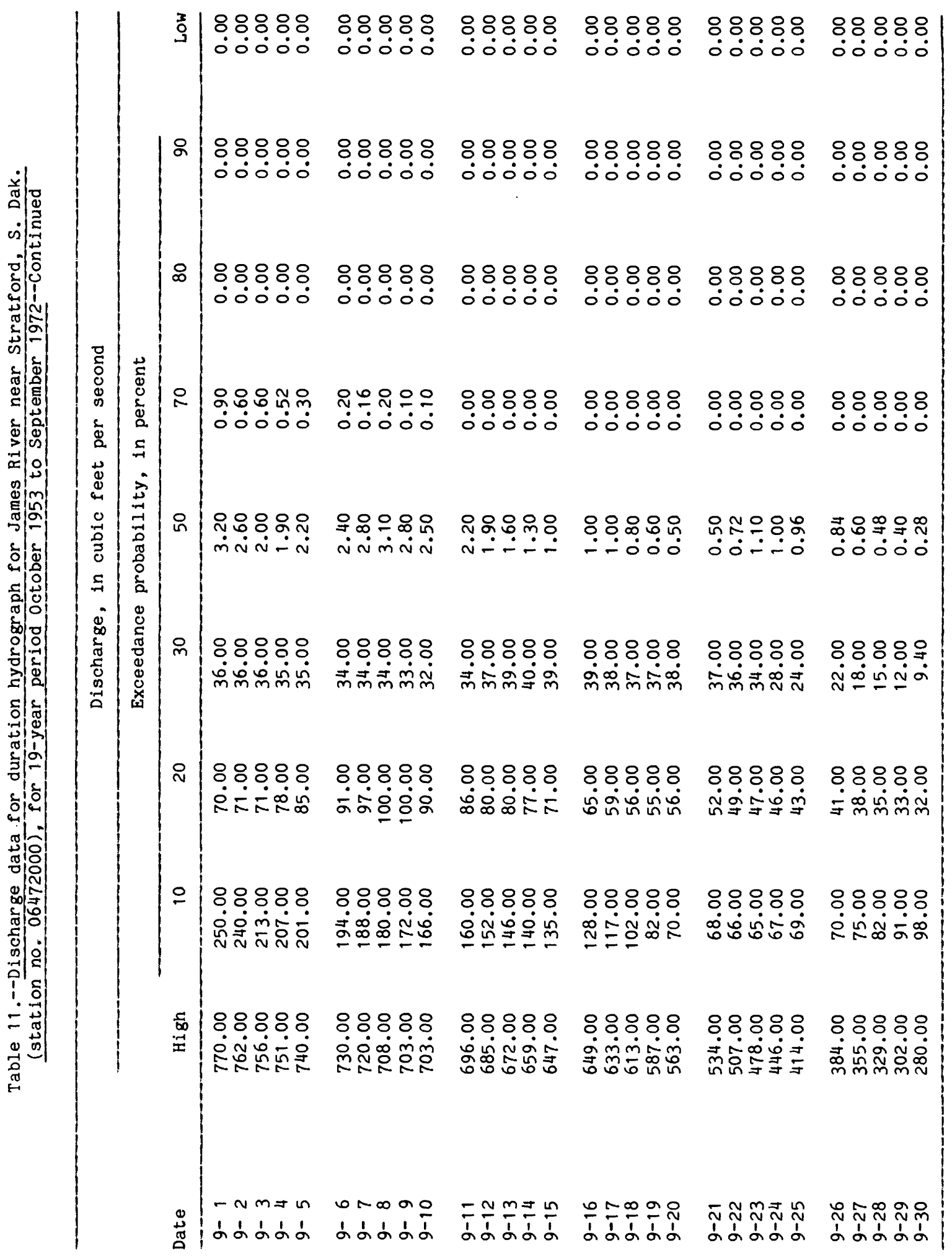
















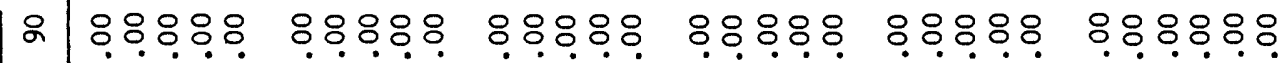
ஸ்0்

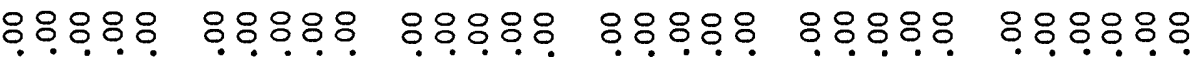

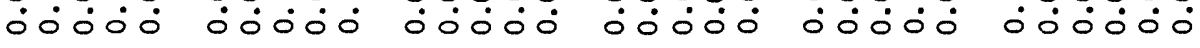

귱ㅇ ৪৪5ㅇ ৪৪৪৪৪ ৪৪৪৪৪ ৪৪৪৪৪ ৪৪৪৪৪৪

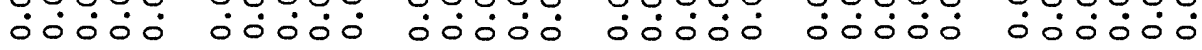



Ұं





in

:००:० :०৪:৪

$\circ: \circ: \circ$

$8: 8: \circ$



৪:8:8: 퀌워

தं்miñ

的部焉

๓ंล่ำล

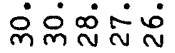

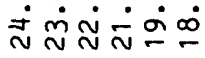

ㅇ

ळ்

80808

৪৪৪৪:

৪०००:

৪৪:০০ ৪:৪০০০

นึ่

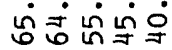

inimín

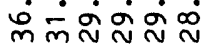

웅

요:०

요드는워

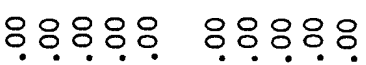

东的需

ต்ํํำ

우웅요

i்ㅇํ요

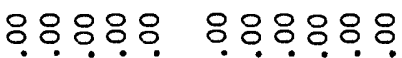

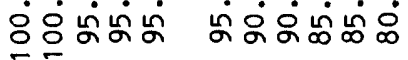

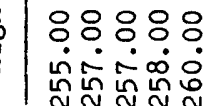

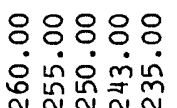

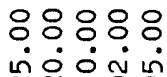

:8:8:

৪৪৪৪৪ ৪৪৪৪৪৪

ํํำำำ

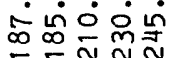

ம்ஸ் ஸ்용

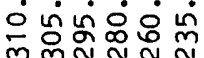

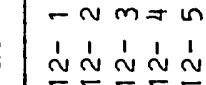

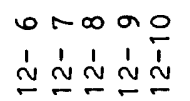

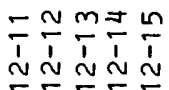

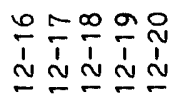

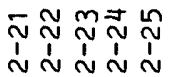

ํㅜํำ ㅇำ

논ำ 
’

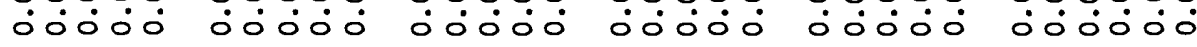

\&

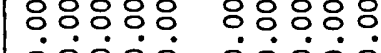
00000 00000 00000

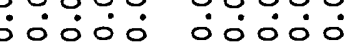

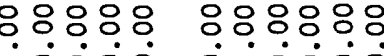
ல0000

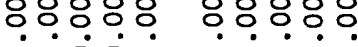
ஸं0ं0்

응융ㅇㅇㅇㅇㅇㅇ نं่inis ৪:৪०: iniv-

융요용 무움

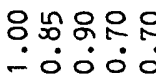

우옹ㅇㅇㅇㅇㅁㅇ 웅ํㅇ 영웅 80808 우웅 ஸ́0ं0்

৪৪:৪: 0000 (1)

00000

융ㅇ 용요 ம்jம்ம்

웅우 웅우움

용용 $\dot{m} \dot{m} \dot{\underline{M}} \underline{\underline{M}}=\dot{0} \dot{0} \dot{0}$

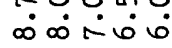

은융ㅇㅇㅇㅛ ท่ 1 ن่

৪৪০০ঃ ৪৪৪০০ œळ் ஸ்

$80: 80$

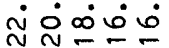

ㅇํㅇ

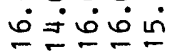

웅ㅇㅇ

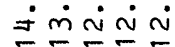

응워오유 ó 0 ơ

용ㅇ 용요 ทำงินี่ 㞥 $\bar{m} \dot{m} m$

웅ํㅇํำ புற் 웅우웅 우유웅

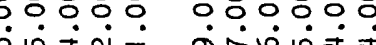
mmnmm mmMN N N

৪৪৪৪৪ ৪৪৪৪ঃ 워욤요 웅ㅇㅇㅇㅛ

88:88 8088: ท்ட்

৪৪:০০ ০০০০০০

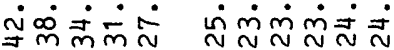

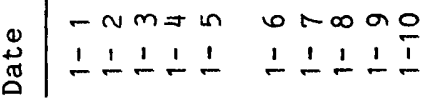

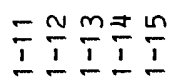
눈ำ원워

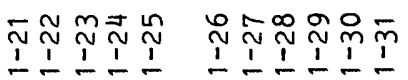




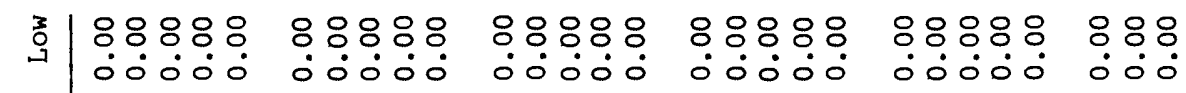

ட்|

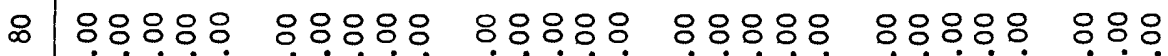

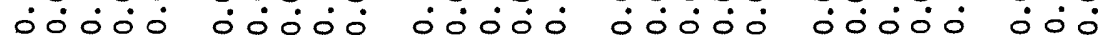

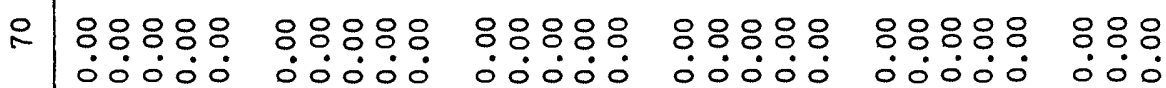

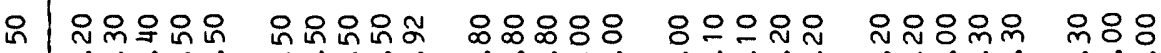

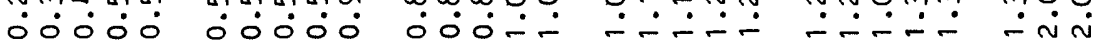

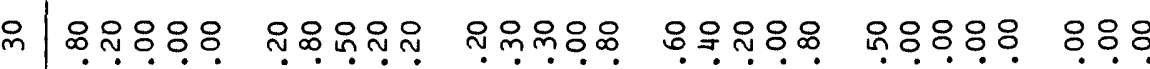

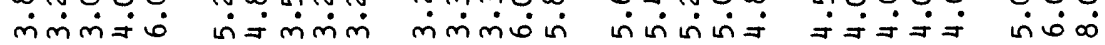

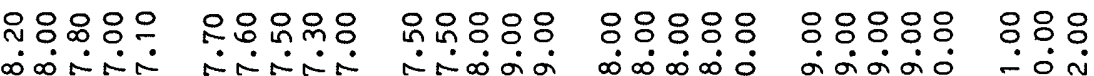

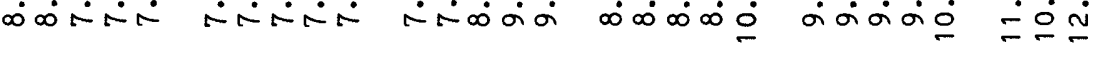

인 चंघंघंघं $\dot{m} \dot{0} \dot{0} \dot{\dot{\varphi}} \dot{\varphi}$

৪৪৪৪: ৪:৪৪: ம்

$8: 88: 8: \circ$

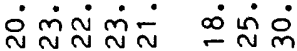

-

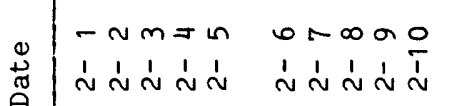

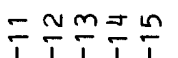

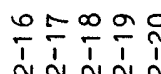

พจะับ 


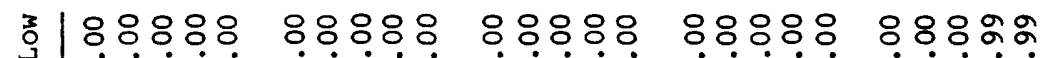

영ㅇㅇㅡ

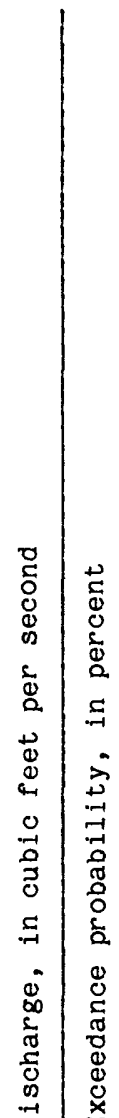

2

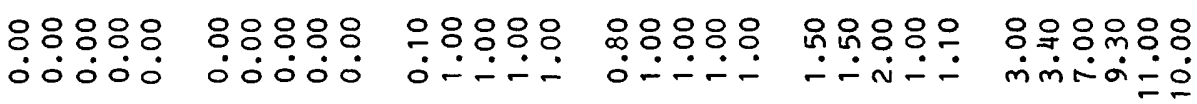



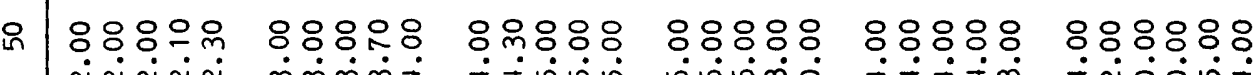

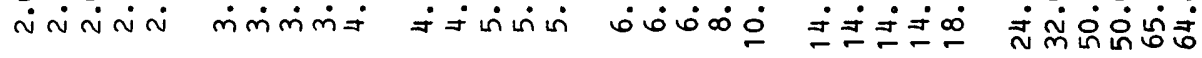

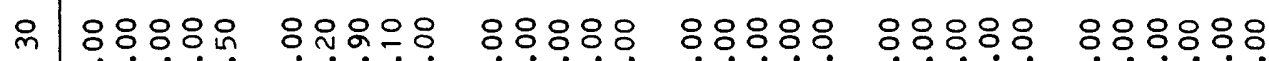

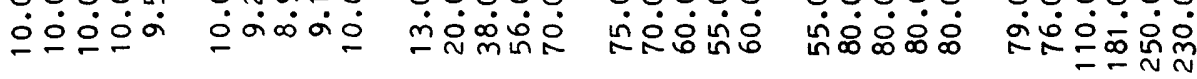

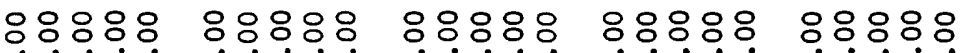

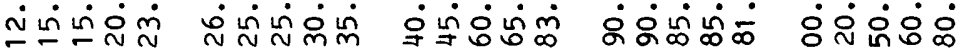

$8: 8: 8:$

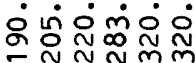

으

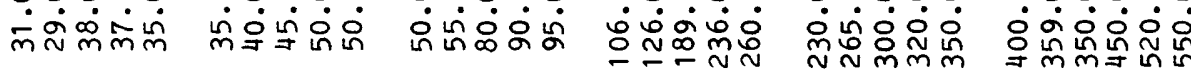

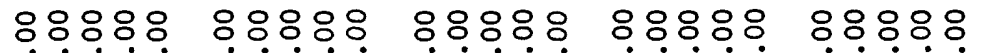

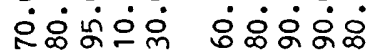

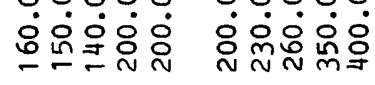

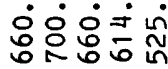

৪৪৪:০০

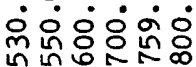

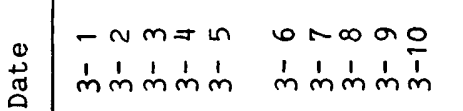

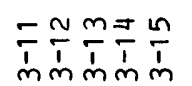

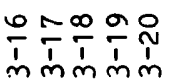

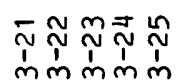

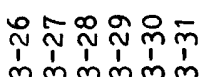




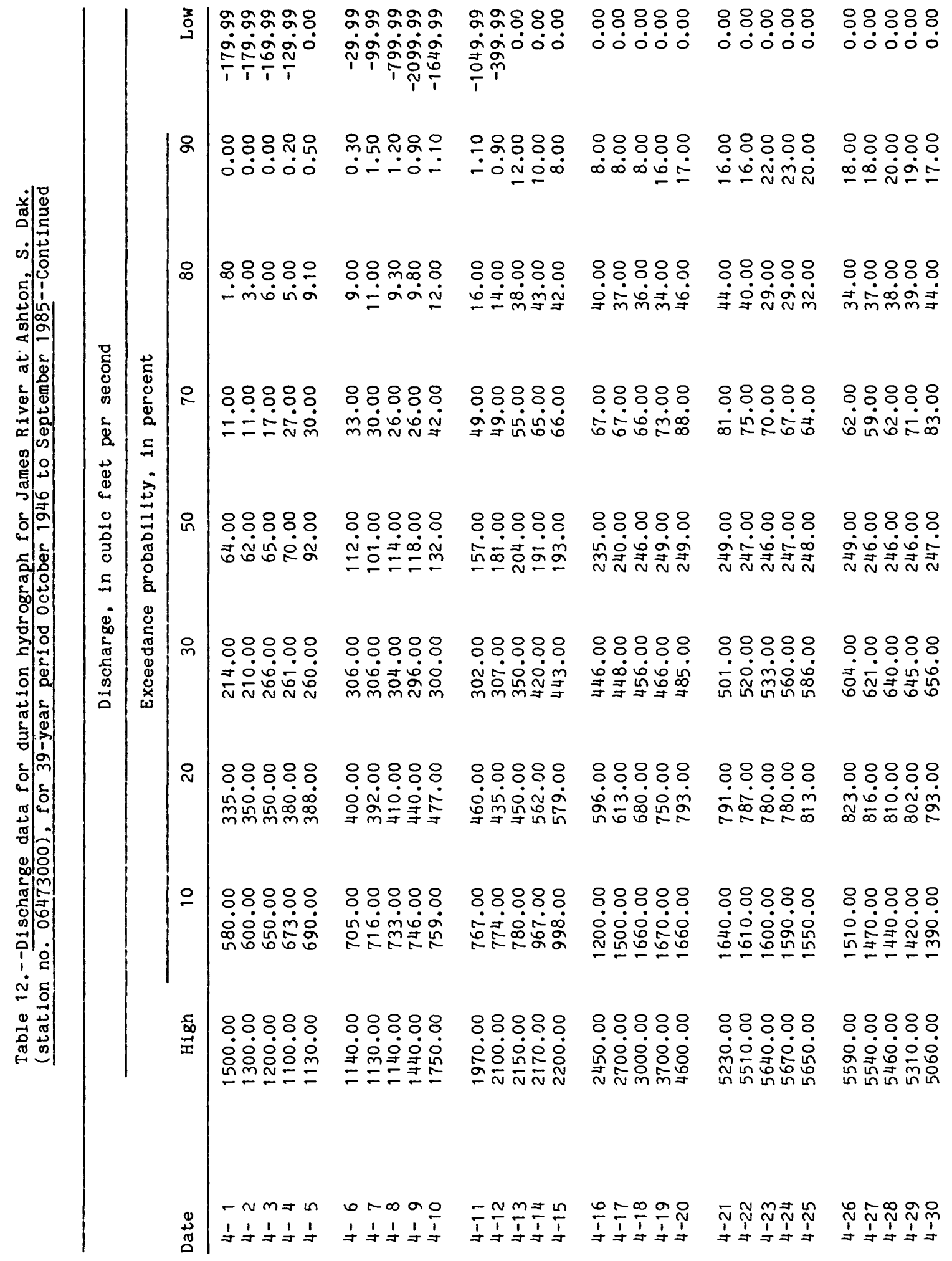


శُ|

৪৪৪:৪

$88888 \quad 888888$

용ㅇㅇㅇ 웅요윰워

잉요융 응요우

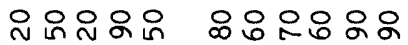

ஹ் ற்ற்

ํำi七

ம்

mंरक

쇼요

$\sim \infty \omega \infty \circ \dot{0}$

\&

$\circ: 8008080 \%$

웅유

요유요

$8: 88:$

웅ํㅇำ

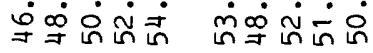

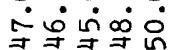

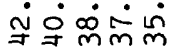

लंख்ं

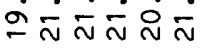

웅

৪০০০০ ৪০০০০

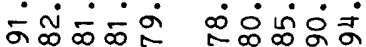

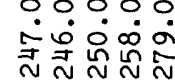

요

요요 :88:०

ப்்่

ஆ̊ㅇㅇㅇㅇ

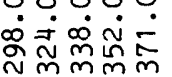

$8: 808$

苂

$8: 0 \% \circ$

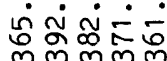

৪:웅

வ்்ல்

:8:8:

은ํํ용

:8:8:০

ธำㅇํํ்

ชิํํㅇ

N

৪:ㅇ 요우

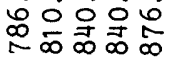

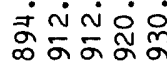

웅웅

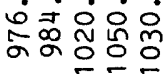

$8: 80 \div$

응ㅎㅇㅎㅀㅇㅛ

:ㅇㅇㅜ

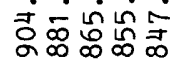

৪:8:8:

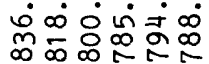

으

:8:8:

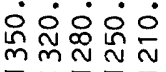

$8: 8: \circ$

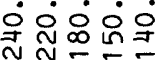

:००:०

৪:०००

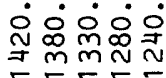

:8:8:

으ㅇㅠㅛ용

:8:8:8

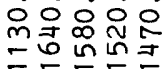

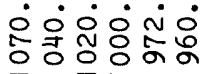

88880

$8: 88 \circ$

ن் $\dot{0} \dot{0}$

$88: 8 \circ$

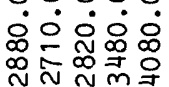

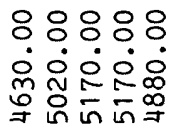

8:88:

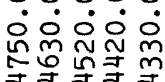

৪৪:৪:৪

웜용

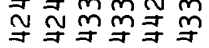

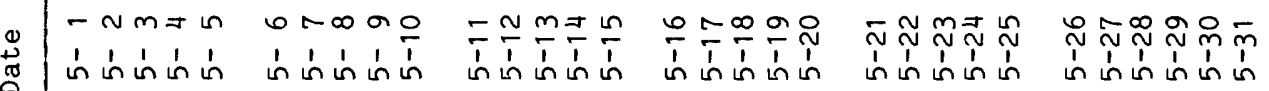




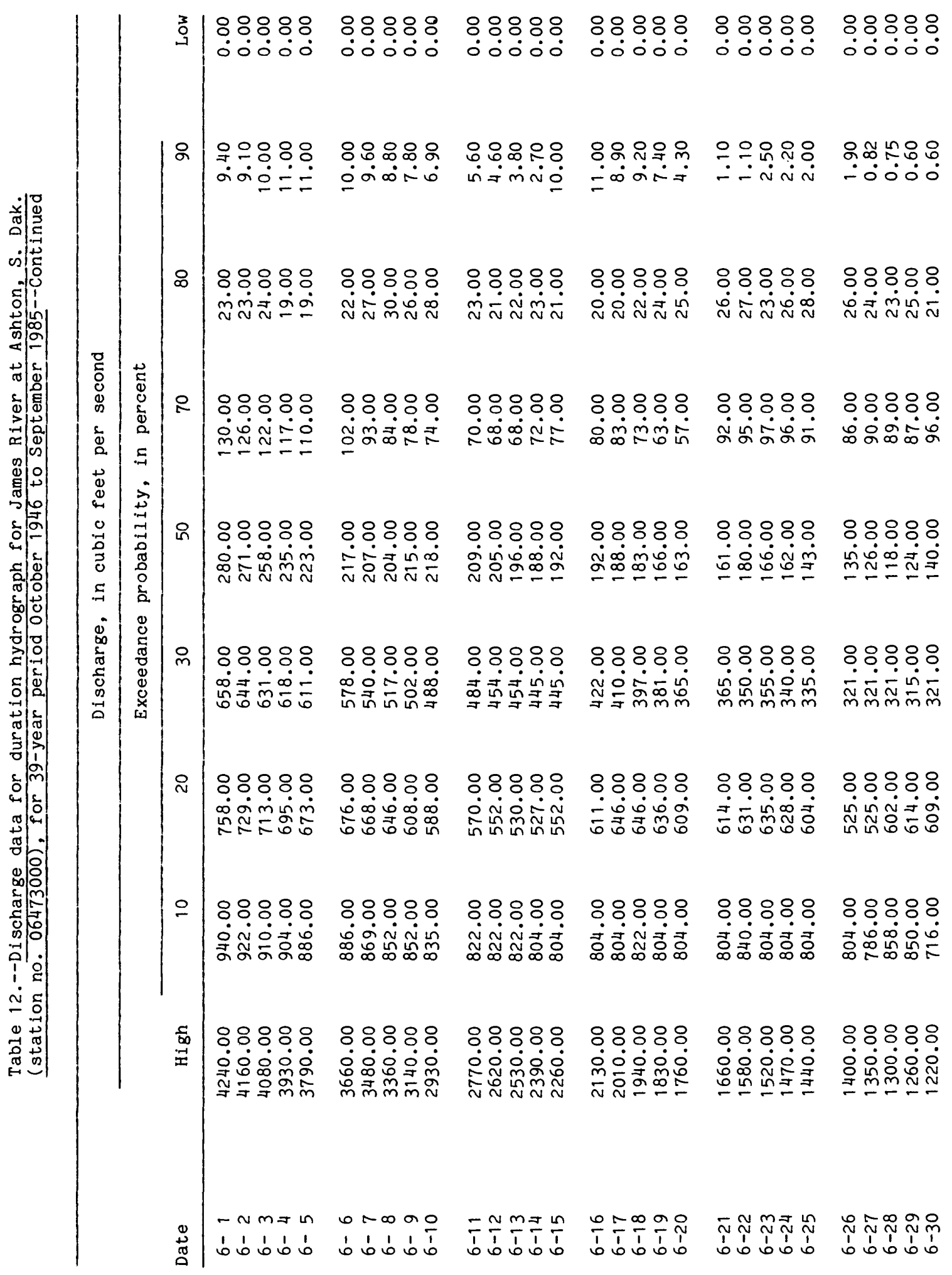




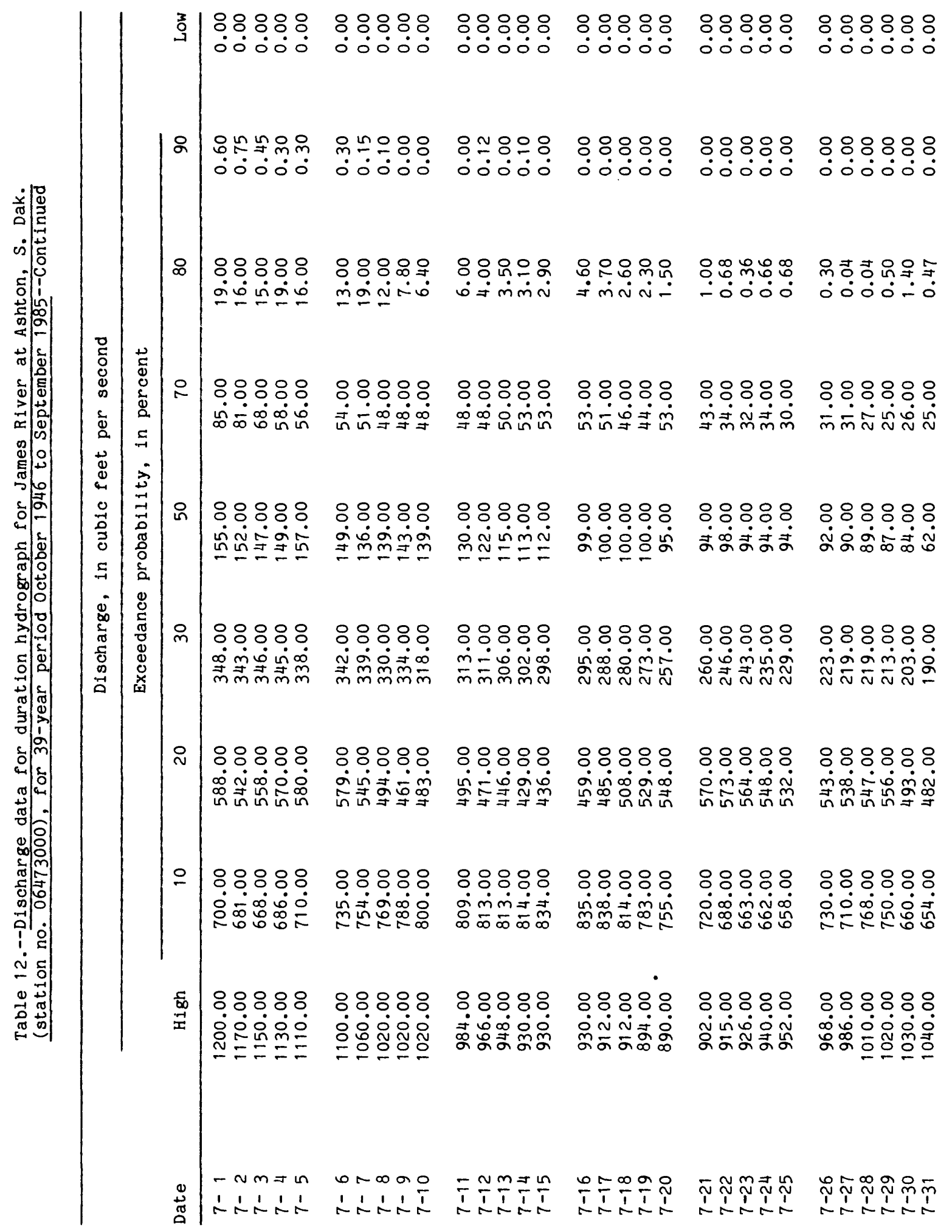




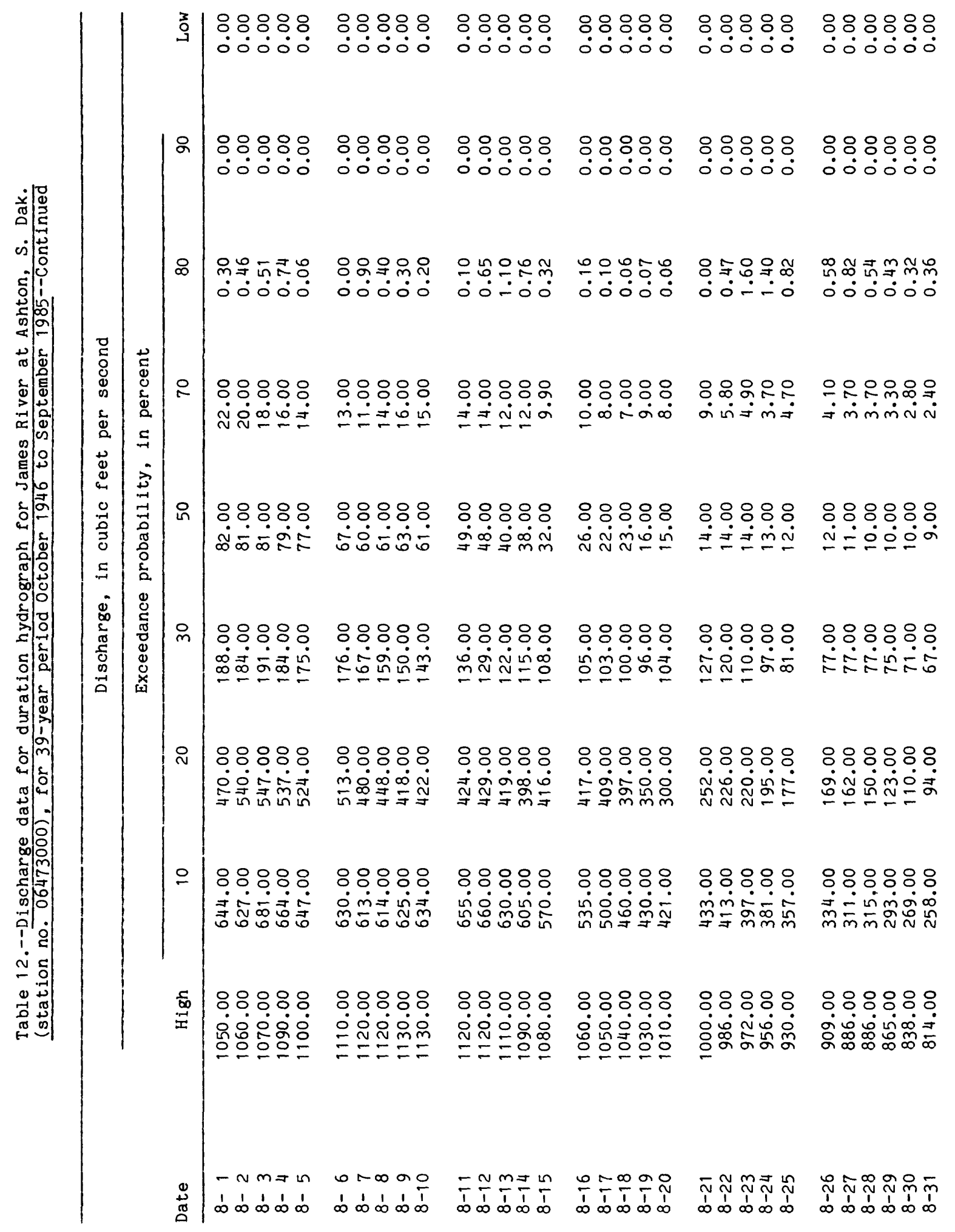




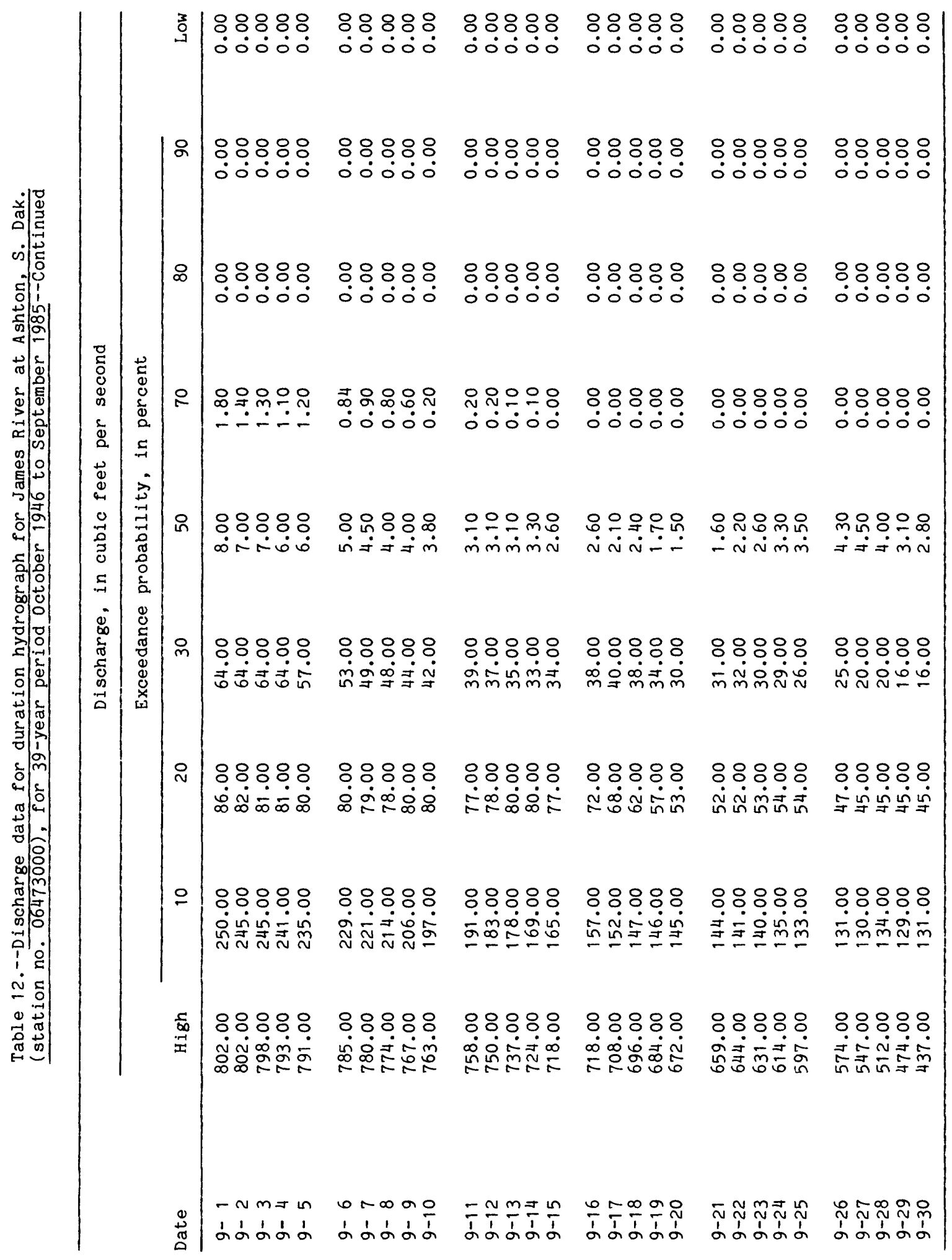




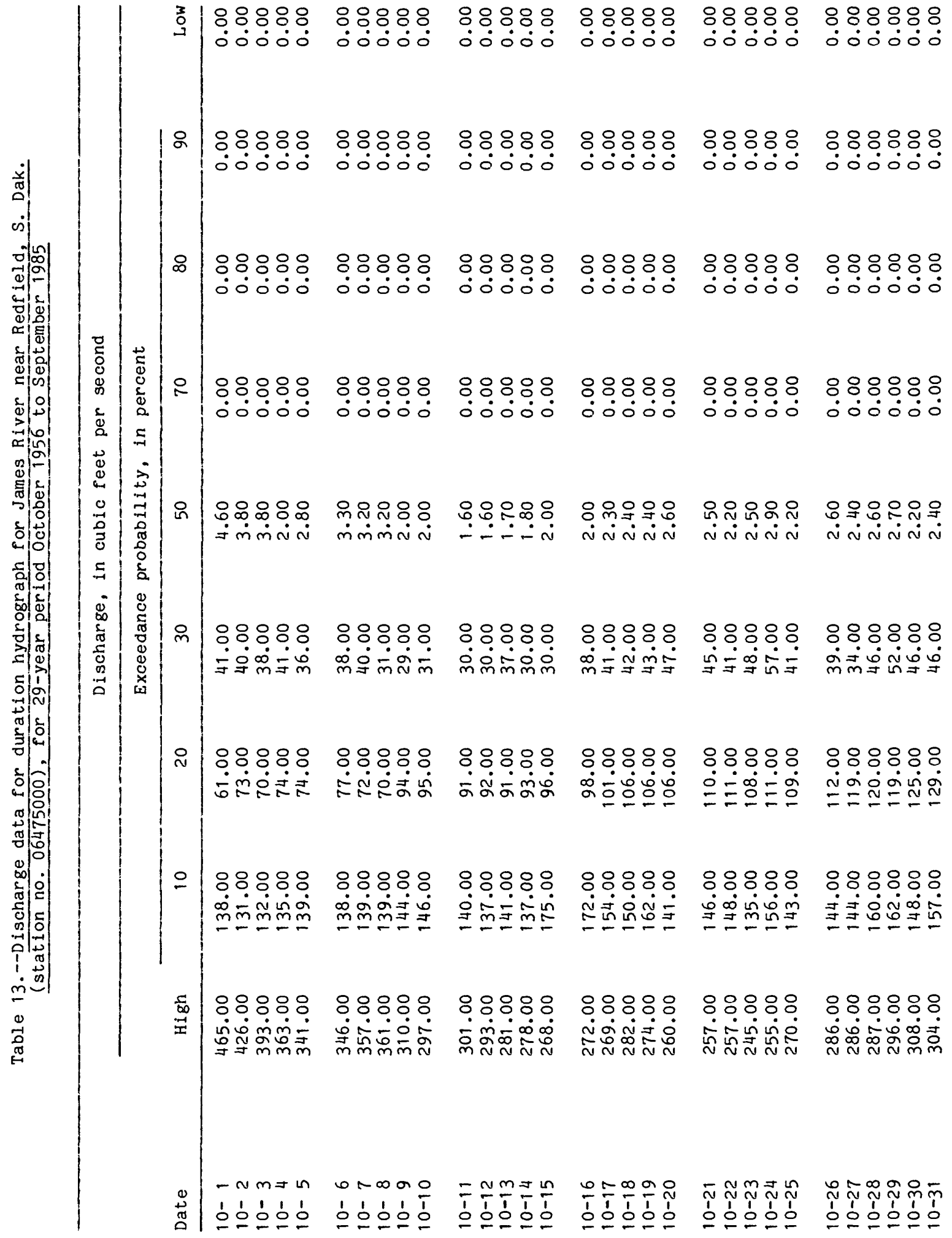




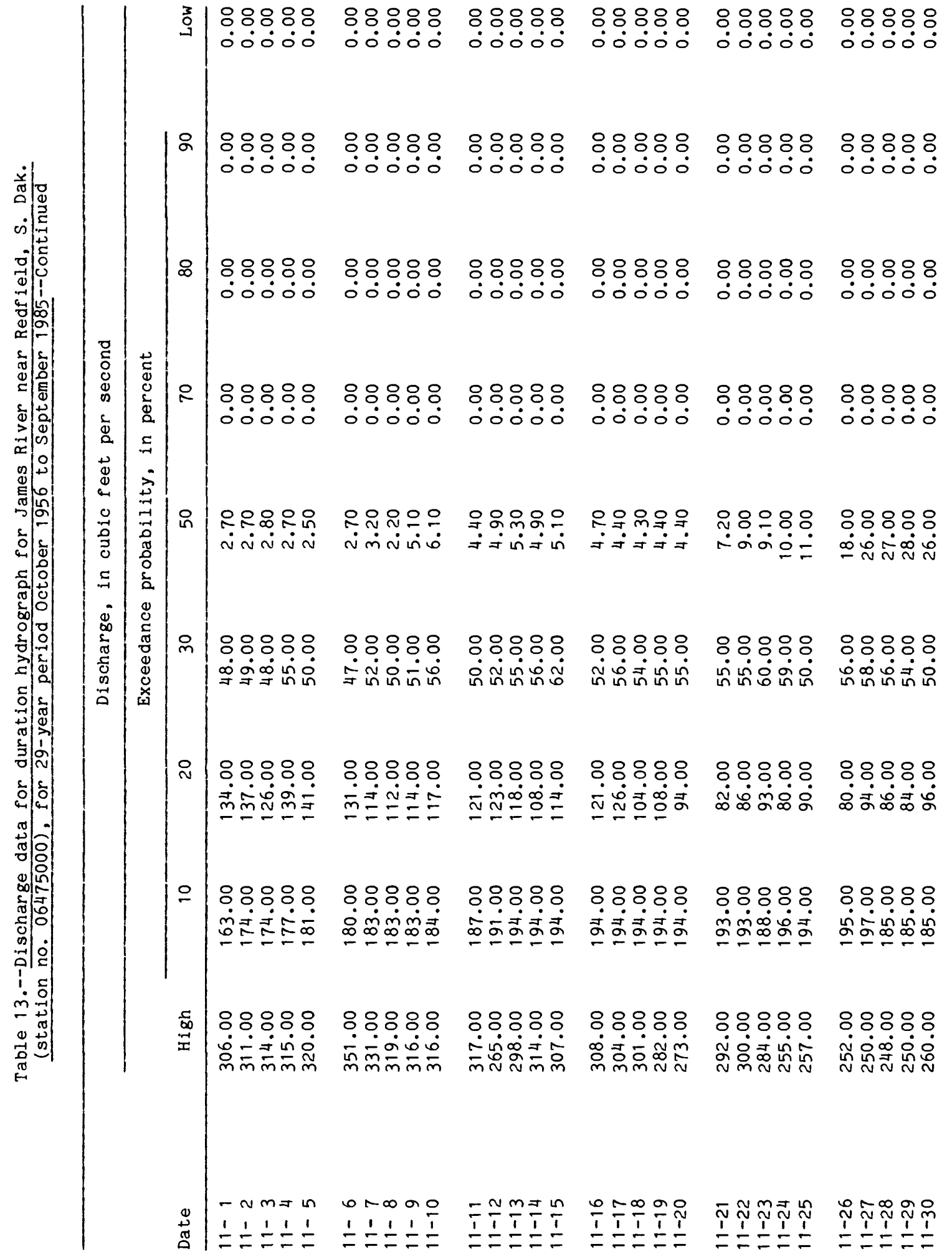




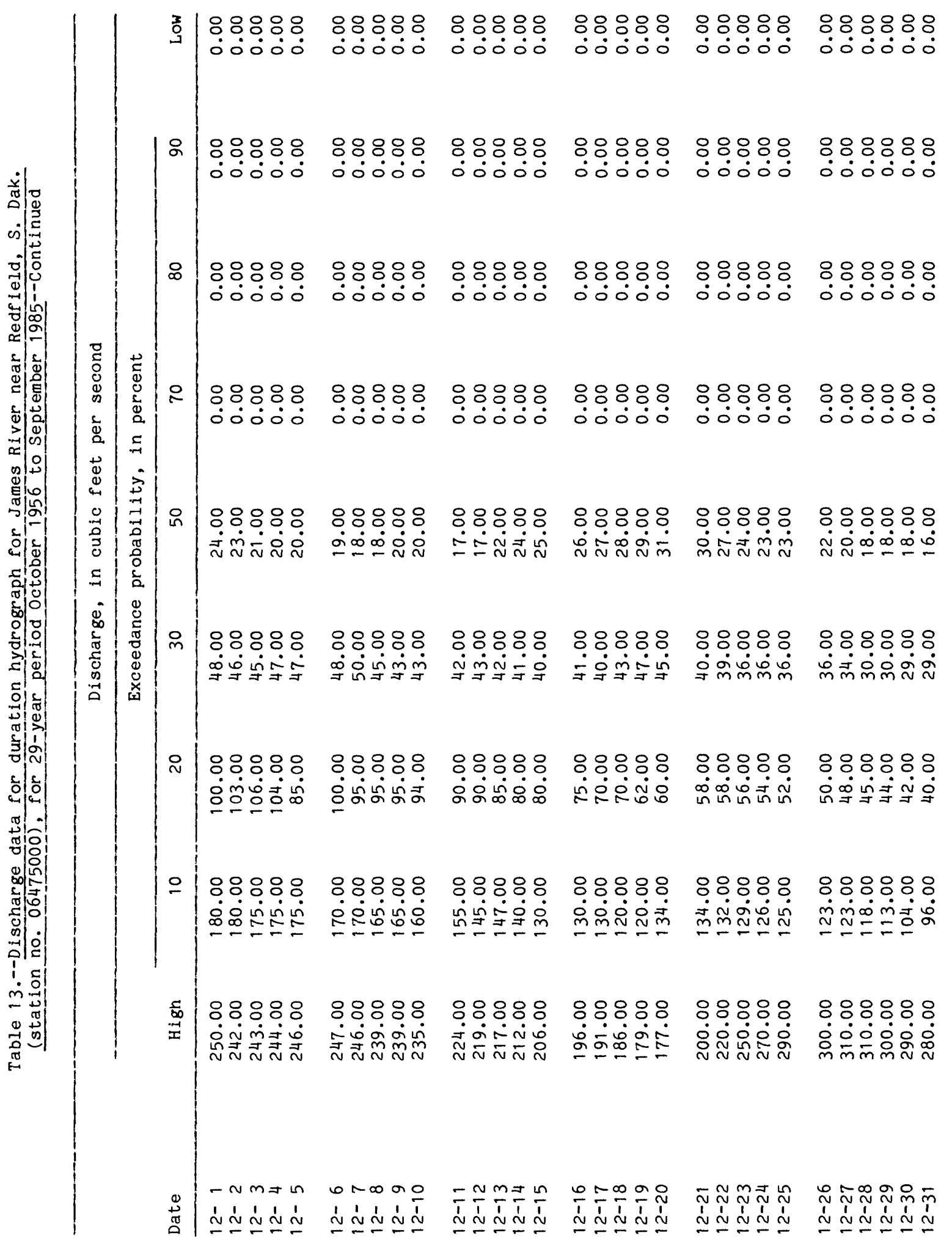




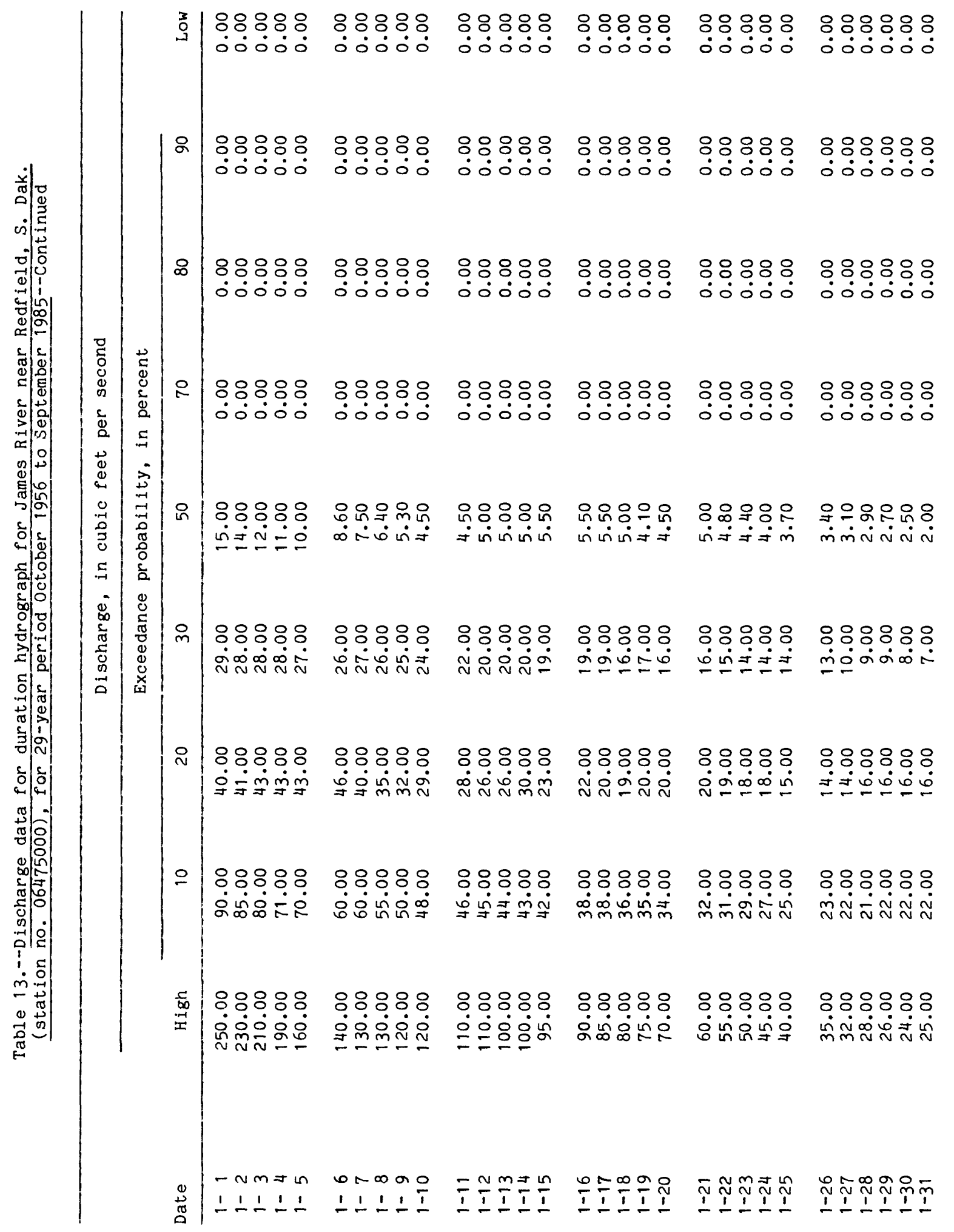




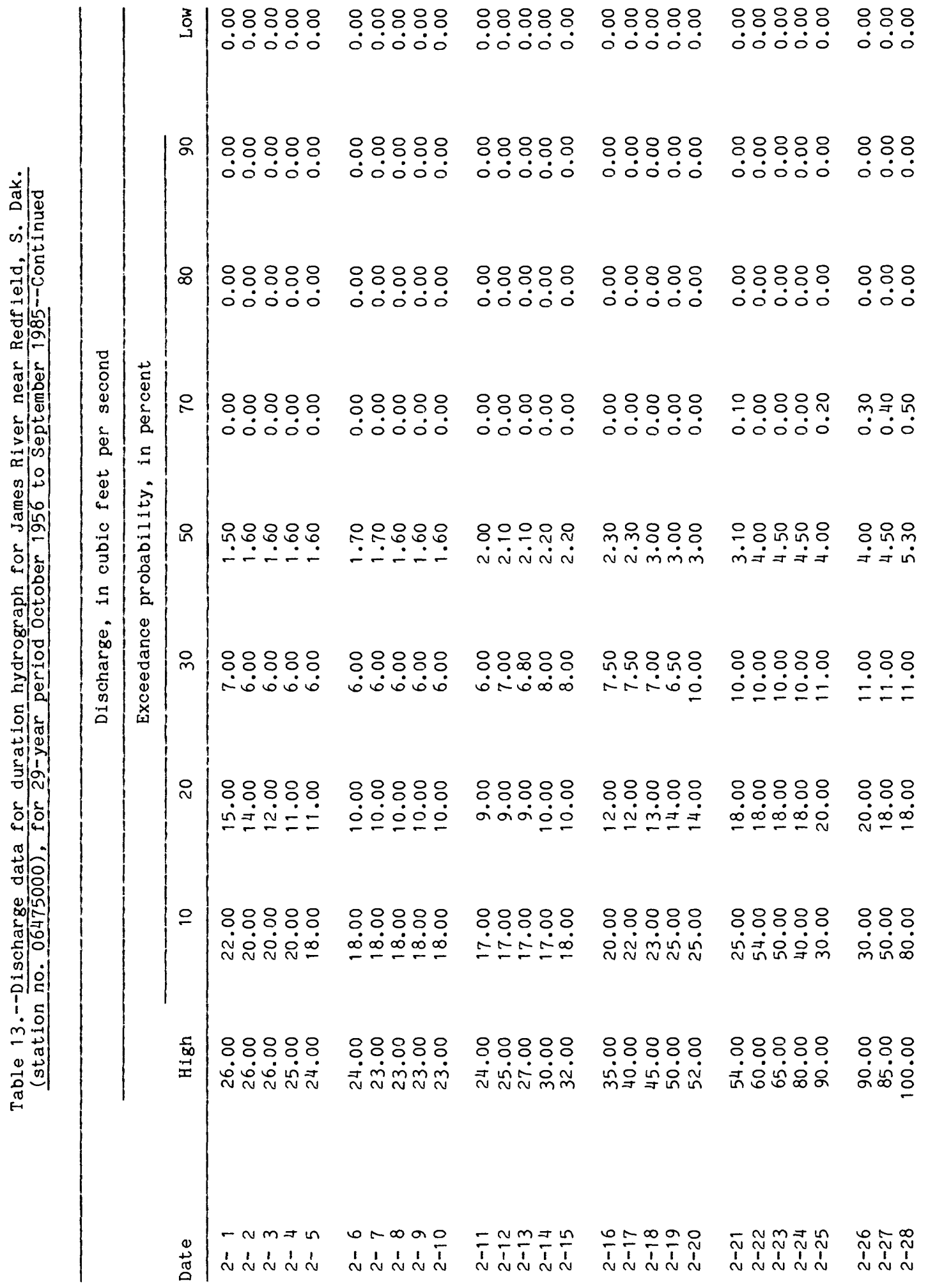




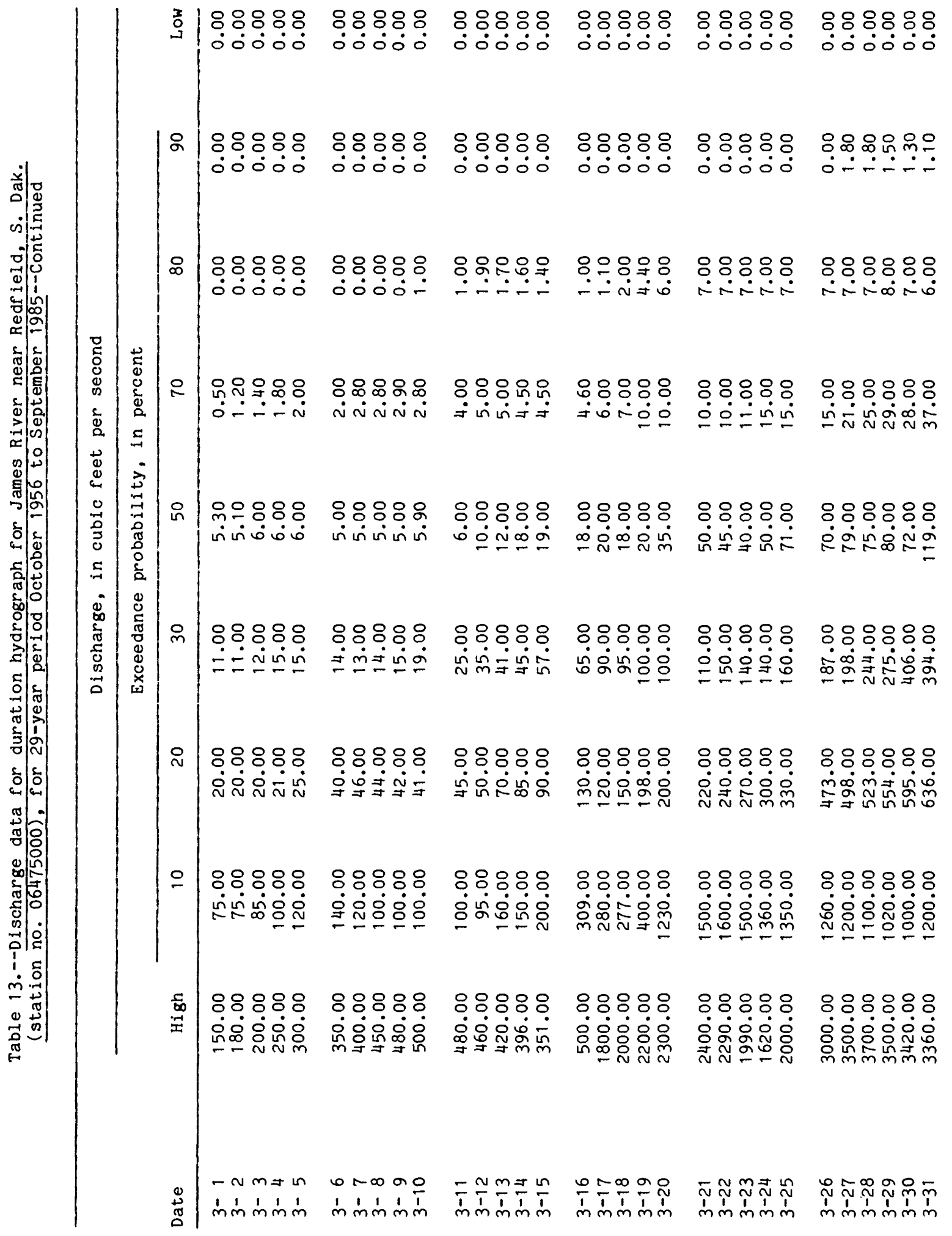




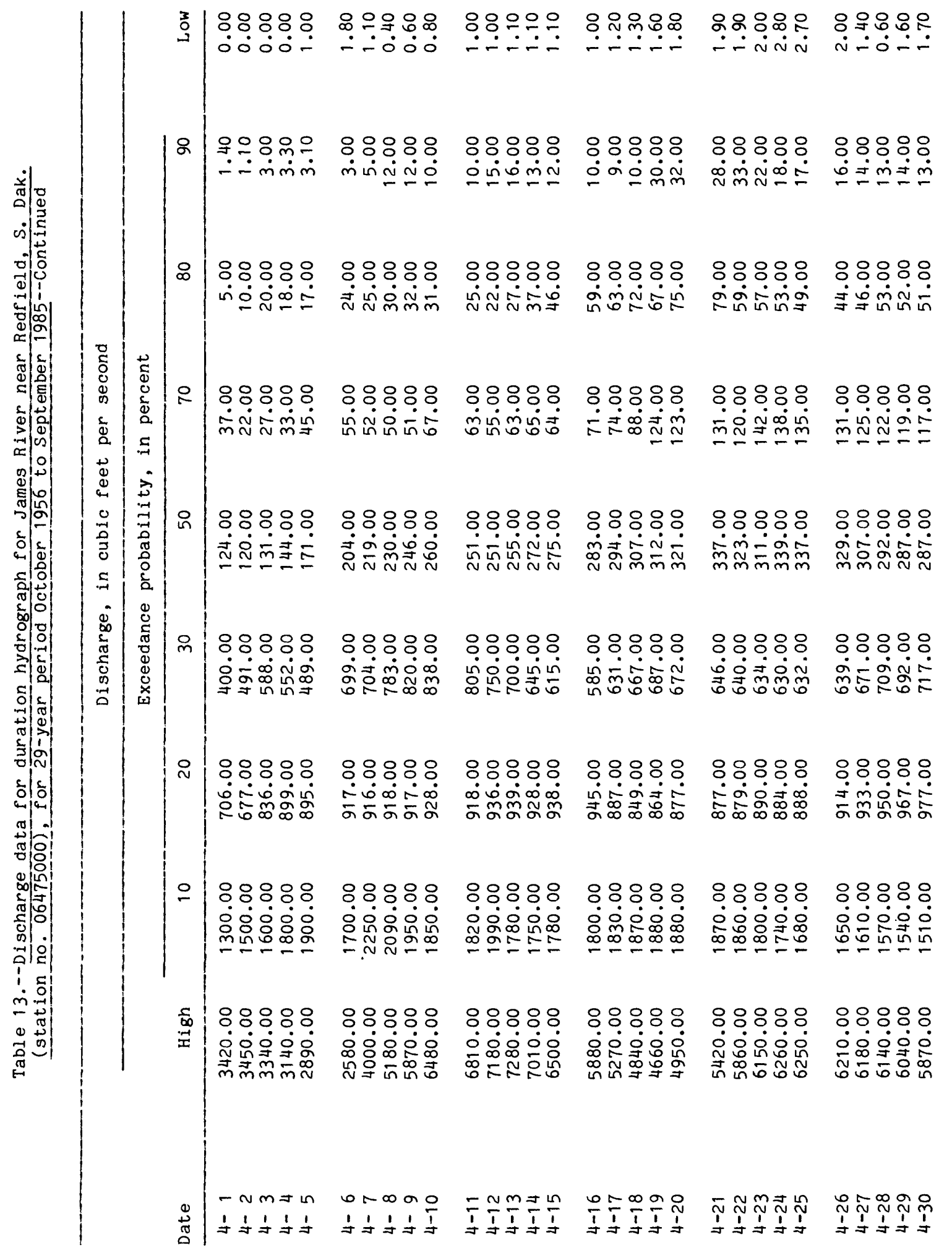




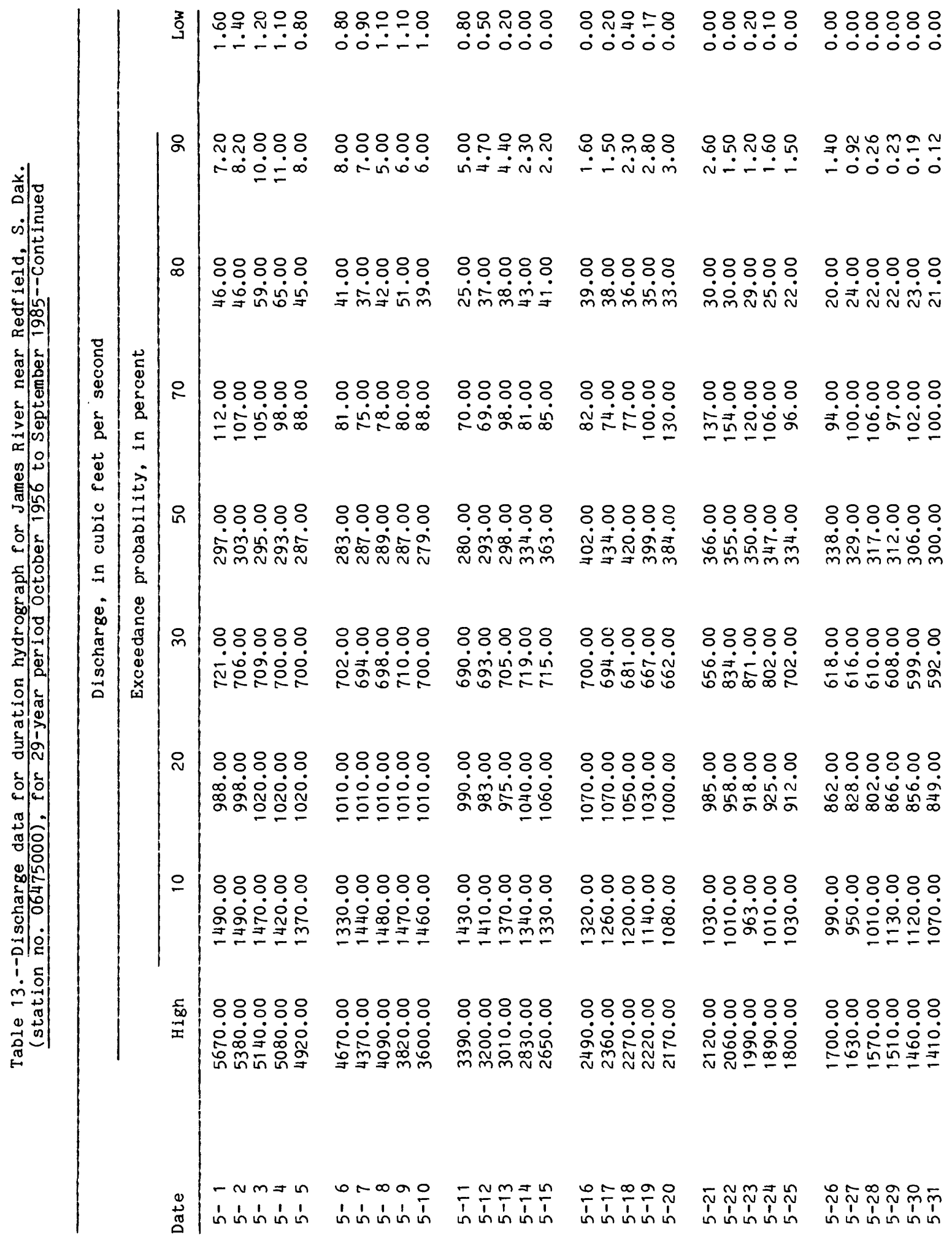




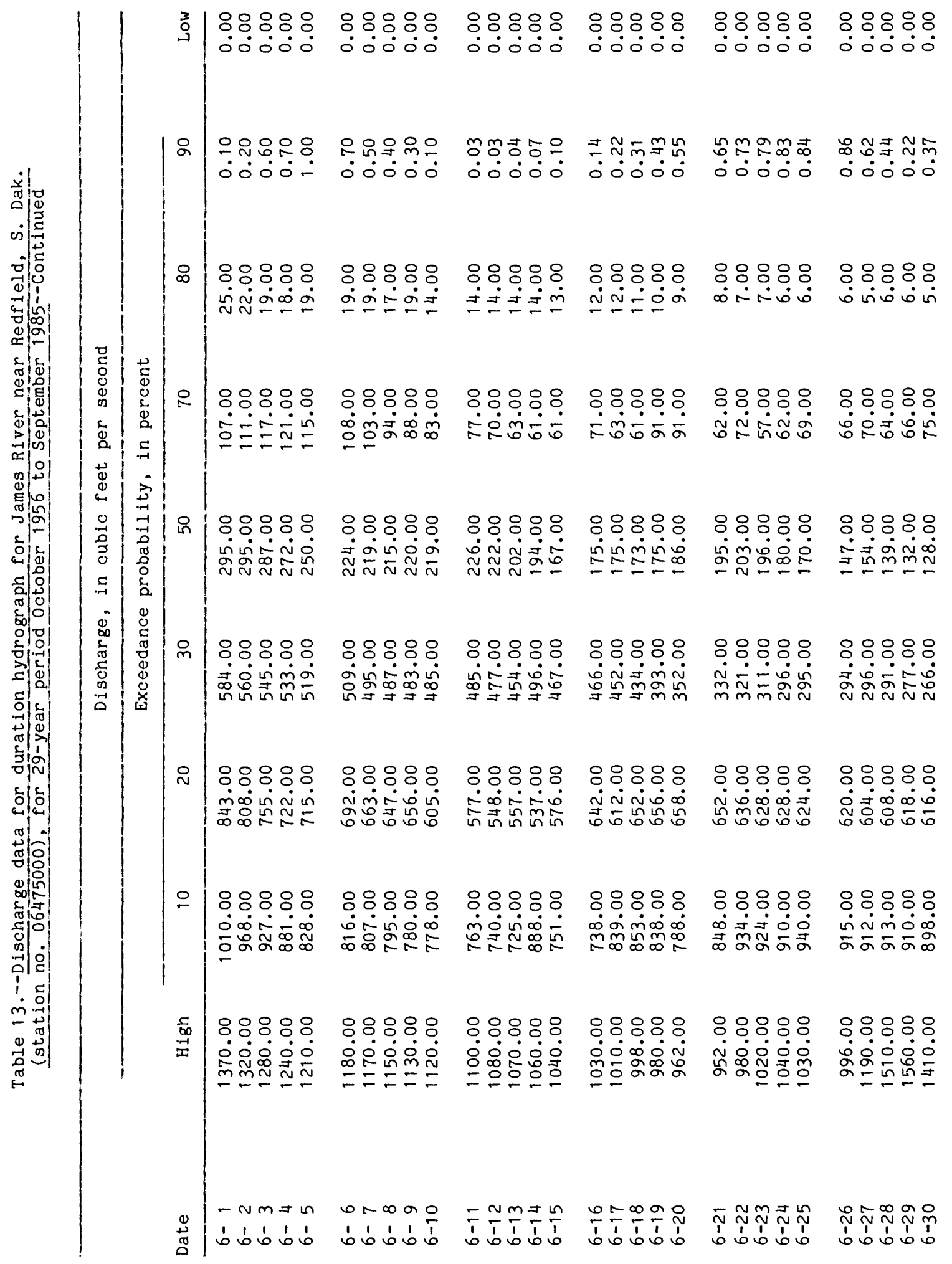




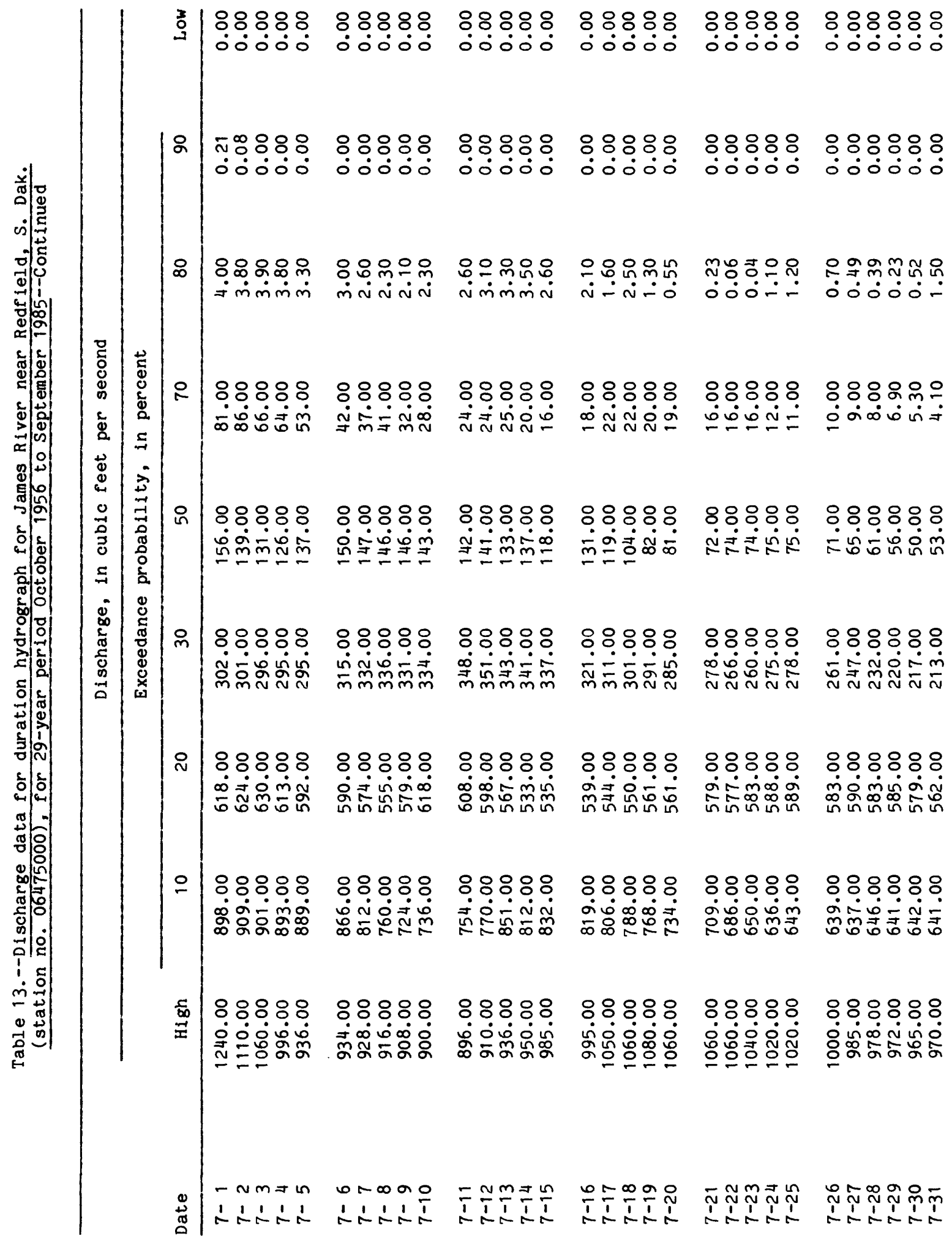




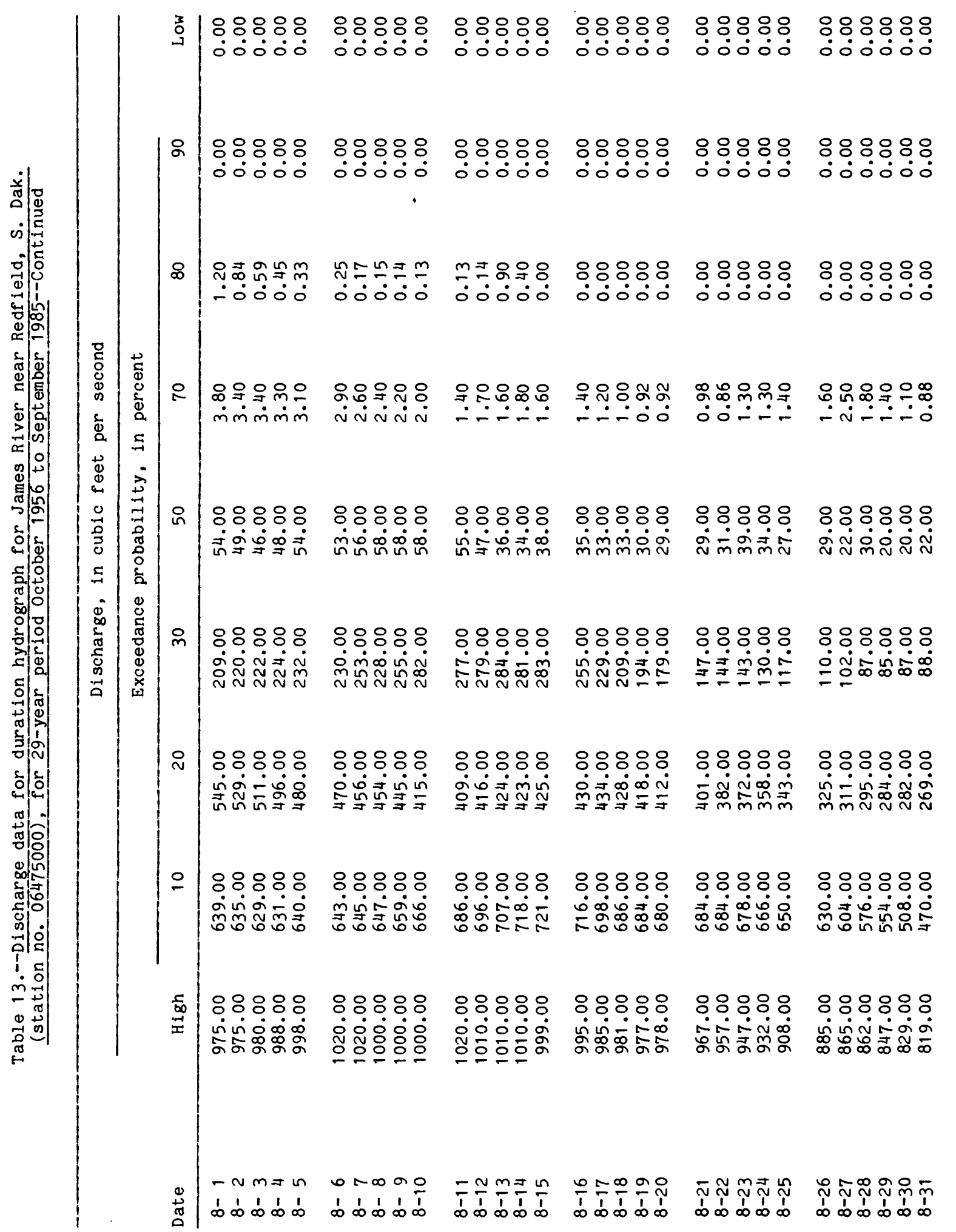




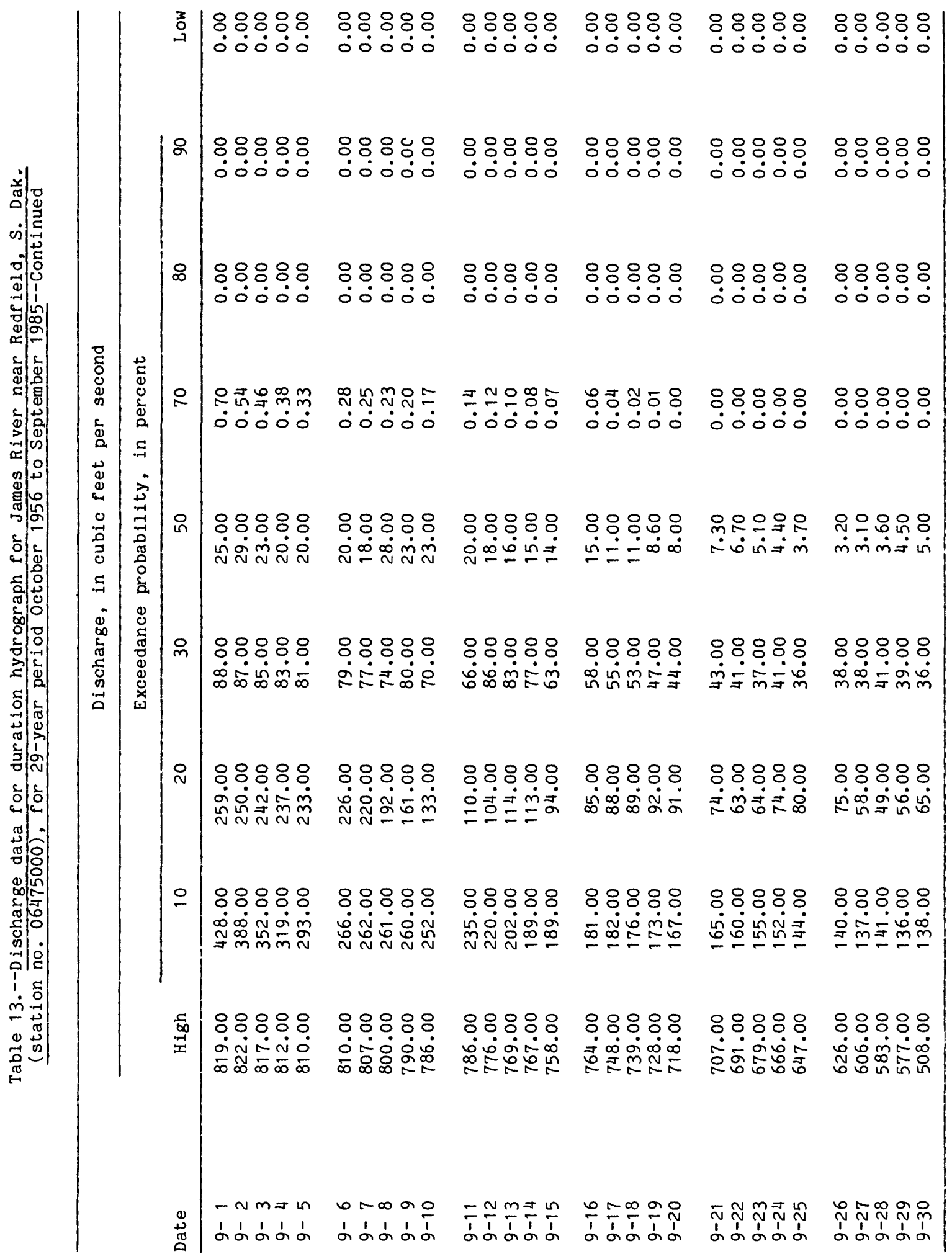




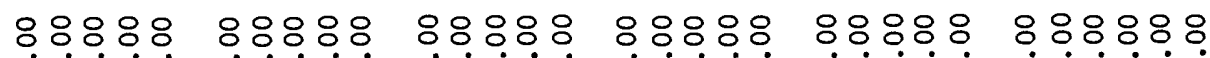

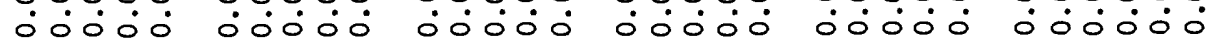

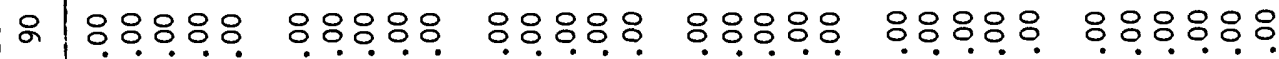

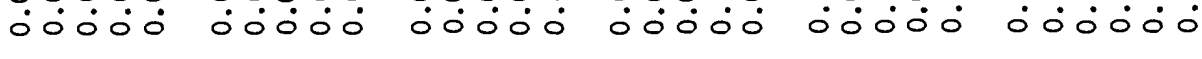

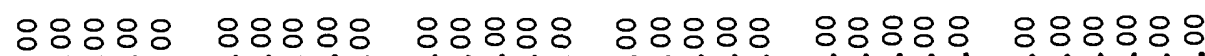

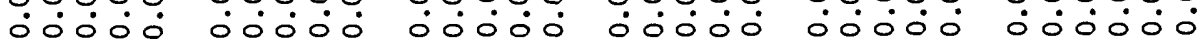

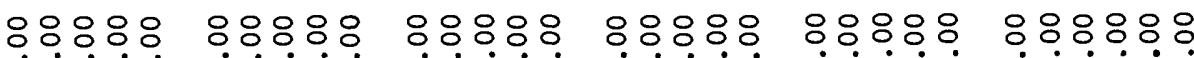

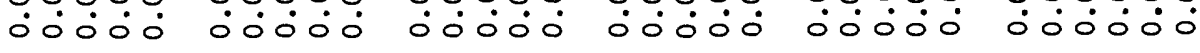

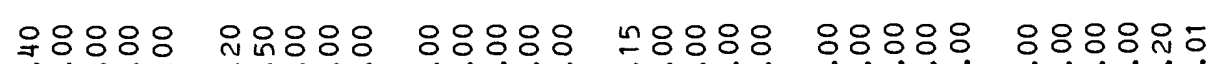

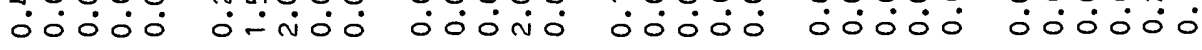

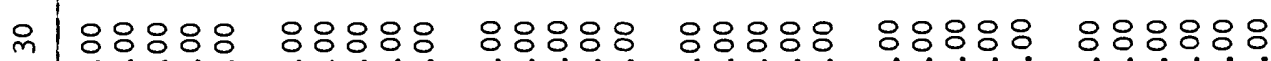

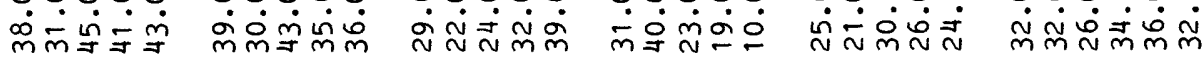

৪৪০০০ ৪০০৪০ ৪০৪৪৪

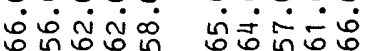
ப்่ن்

$\circ: 88:$ ஸ்่ง்่

우웅

:৪::

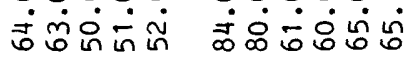

৪৪৪০০ ৪৪০৪০ ৪০৪৪০

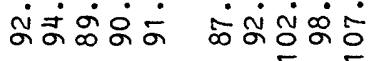

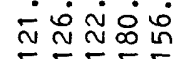

$8: 08:$ $\dot{\bar{N}} \stackrel{\sim}{=} \stackrel{\sim}{=} \dot{N}$

$: 8: 0:$

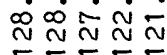

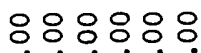

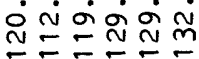

৪৪:৪০ ৪৪৪৪:

৪৪৪:০ ৪৪৪০০

:०:०:

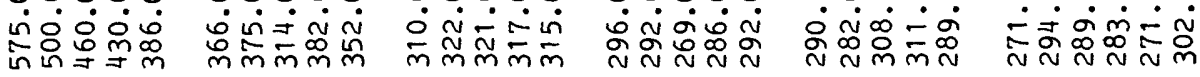

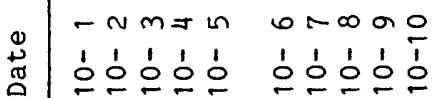

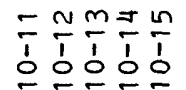

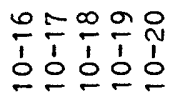

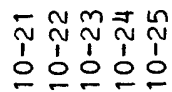

ํㅜㄲㄸㅠำํำ

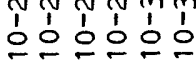




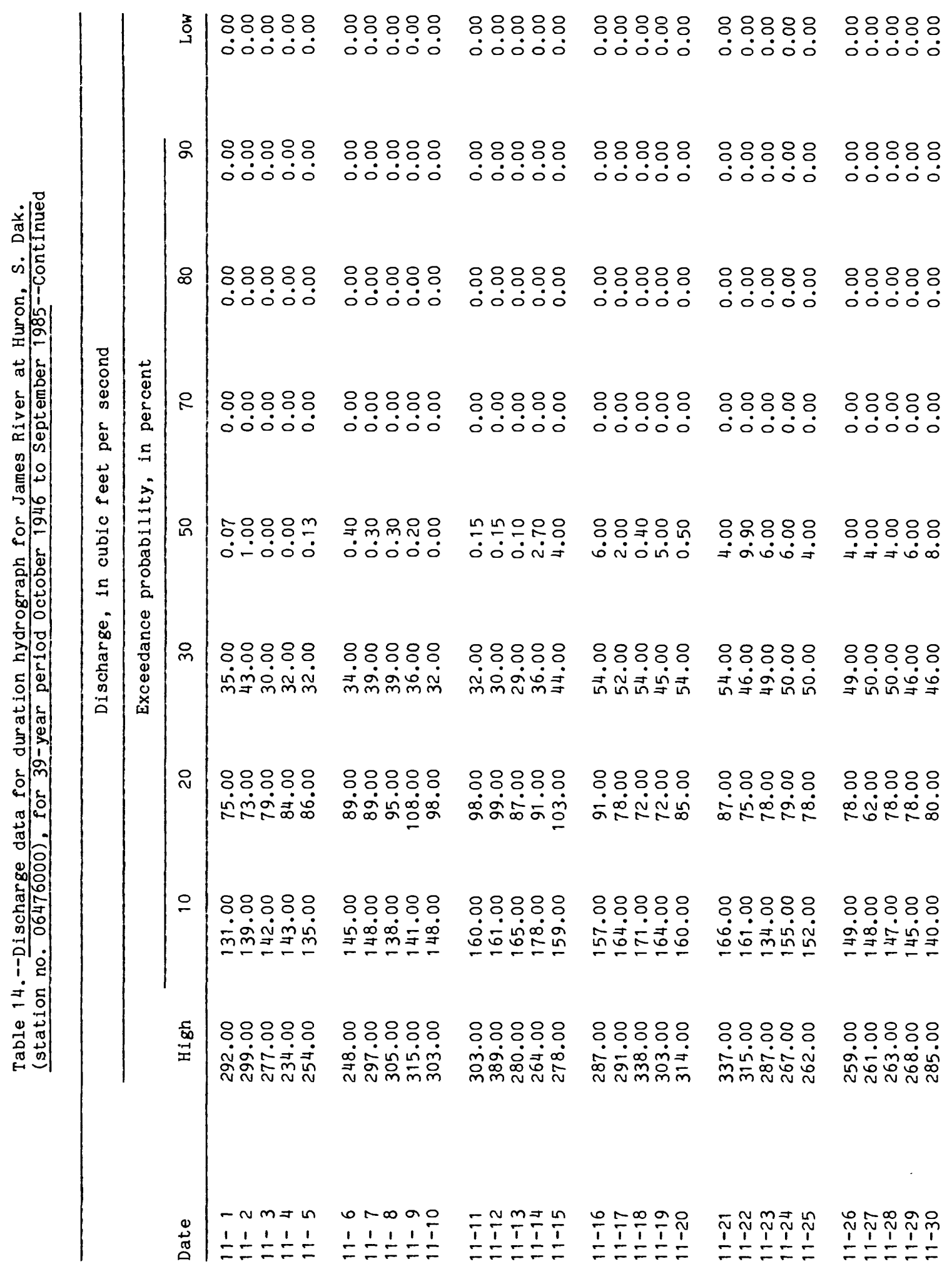




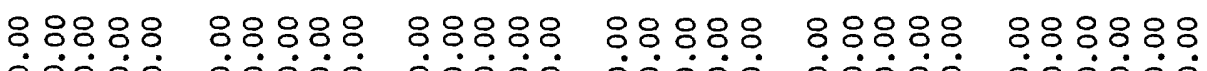

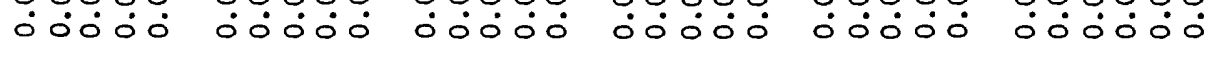

요요

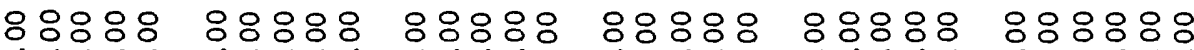

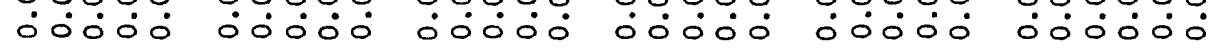

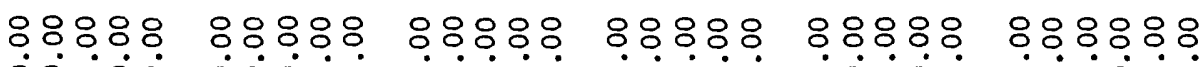

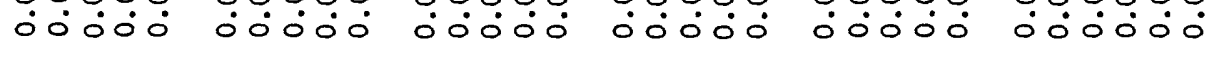

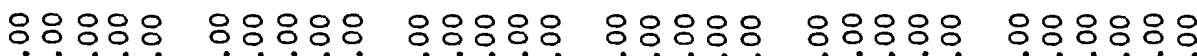

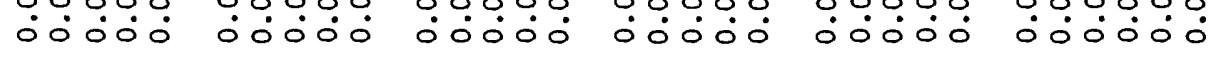

양 요: $8 \circ \div \circ \div$ $\circ \div \circ \div \circ$

$8: \circ \div \circ$

808808

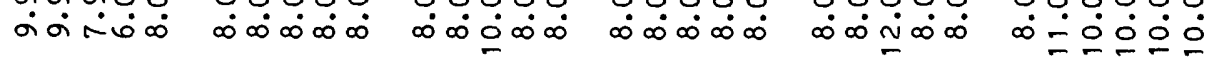

용ㅇㅇ

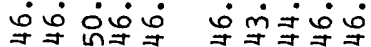

웅ㅇำ

৪๐:০০

80808

ㅇํㅇㅇำ

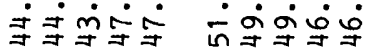

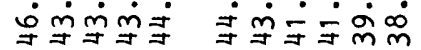

৪৪:০০ ৪০৪:০

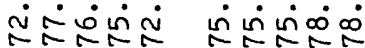

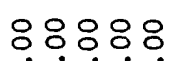

$8: 8: 8$

$80808: 8808:$

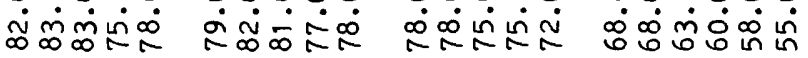

:০০:০ :০০৪০ inं $\dot{0} \infty$ in 웡워영

용ㅇ․

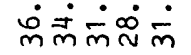

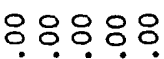

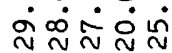

ㅇㅇㅇㅇㅇ 8ㅇㅇㅇㅇㅛ ஸ்亠凶禸் $m-m=$ - - ․ㅗ - - - ……

\section{용ㅇㅇ}

৪:০৪:

0800000000

용․

808080 กิ่ล ํำำ

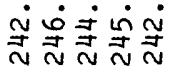
ம்ंن் i.0்

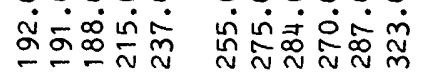

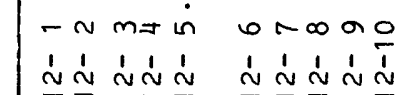

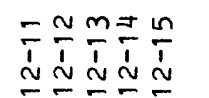

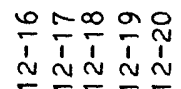

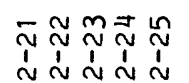

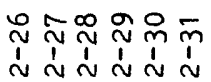

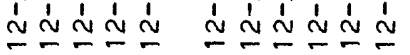




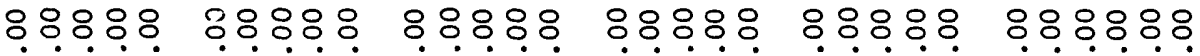

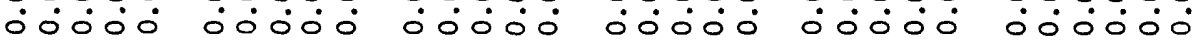

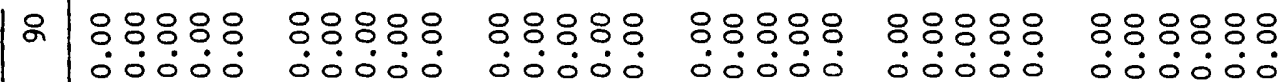
0000000000000000000000000000000

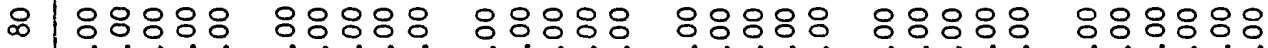

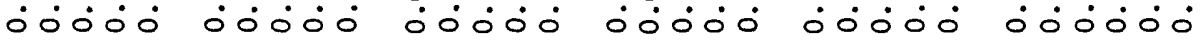

ং ৪৪৪৪৪ ৪৪৪০৪ ৪৪৪৪৪ ৪৪৪৪০ ৪৪৪৪৪ ৪৪৪৪৪৪

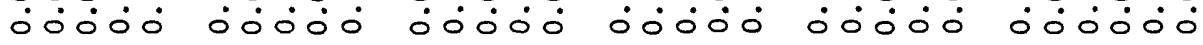

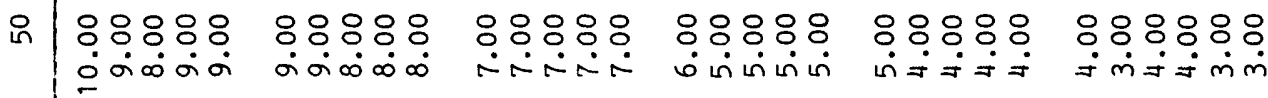

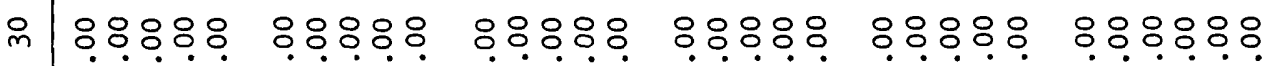

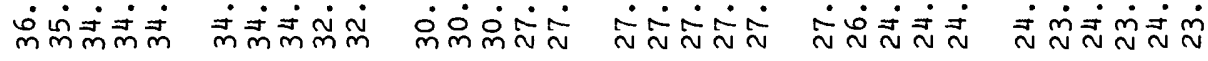

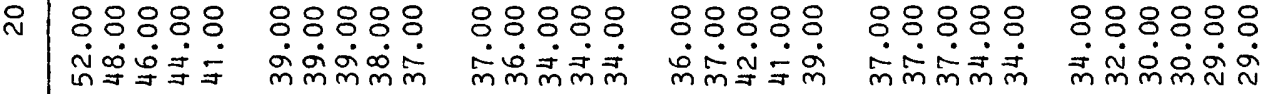

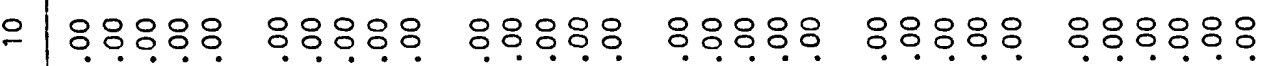

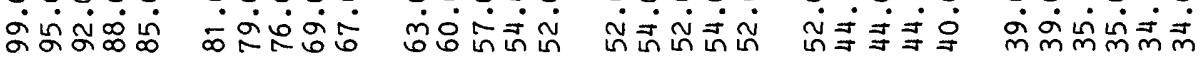

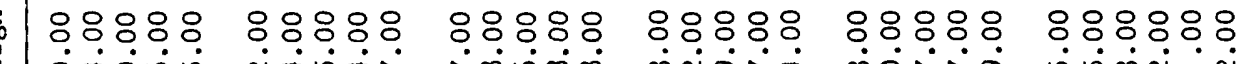
I 离 


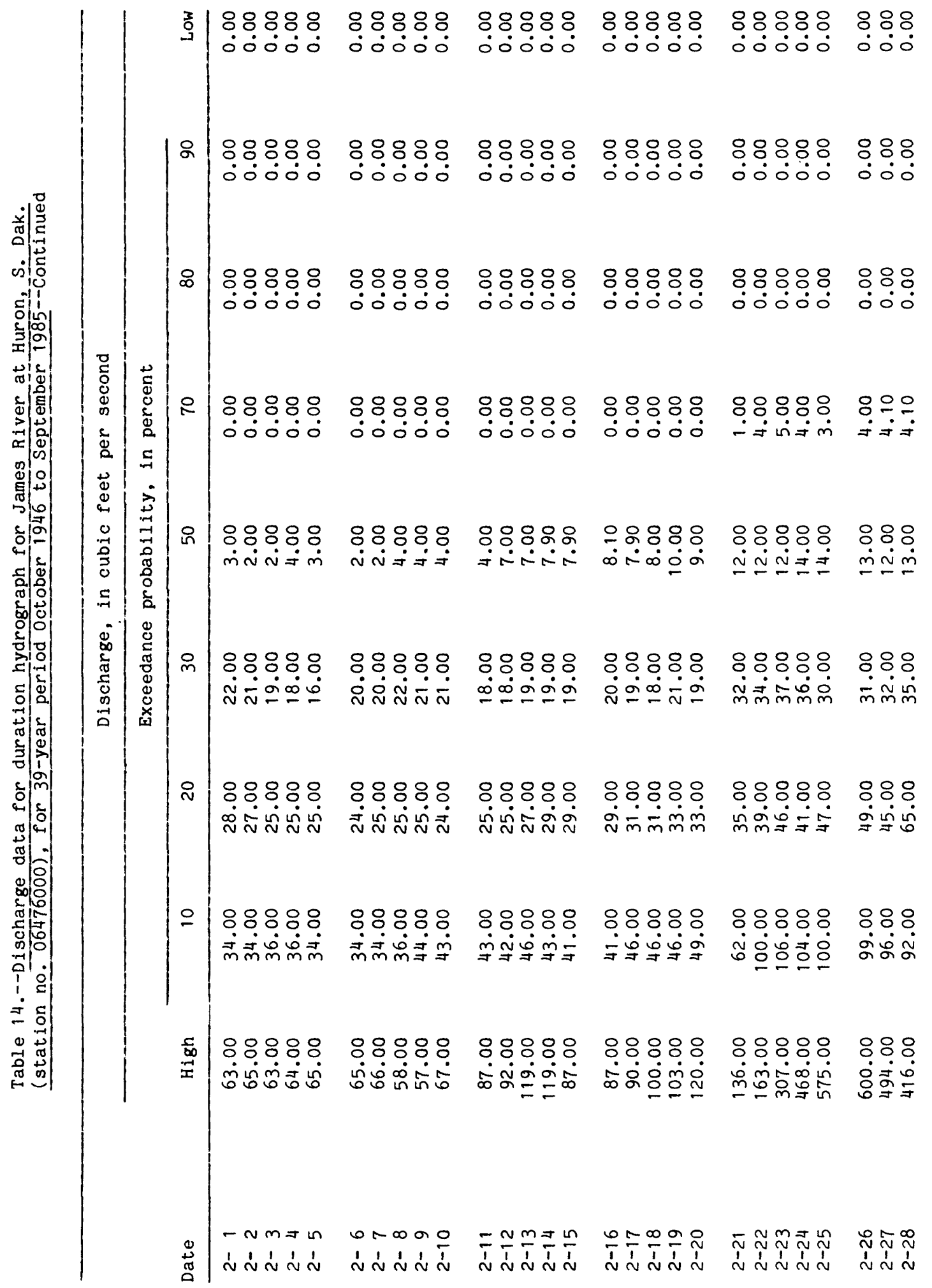




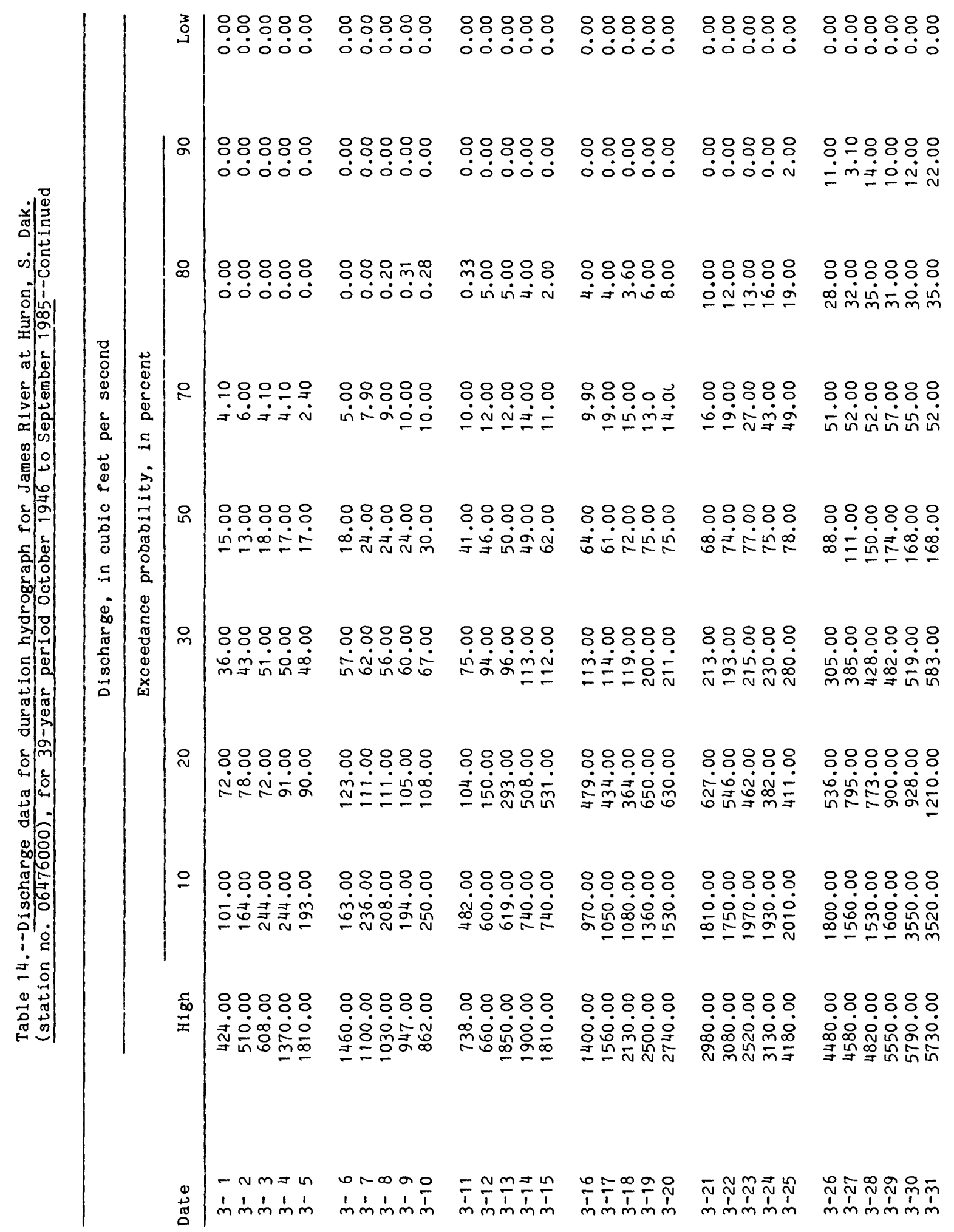




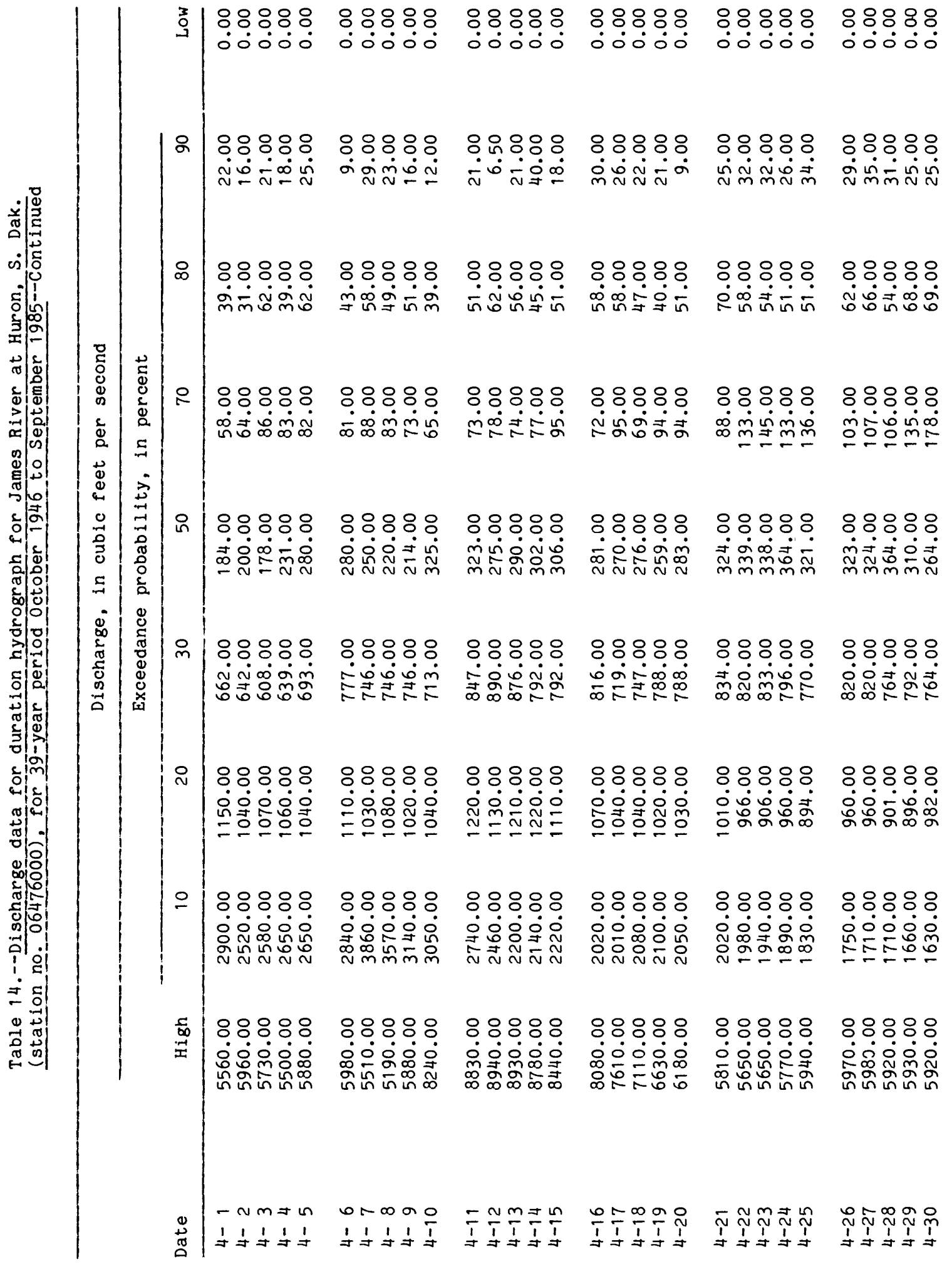




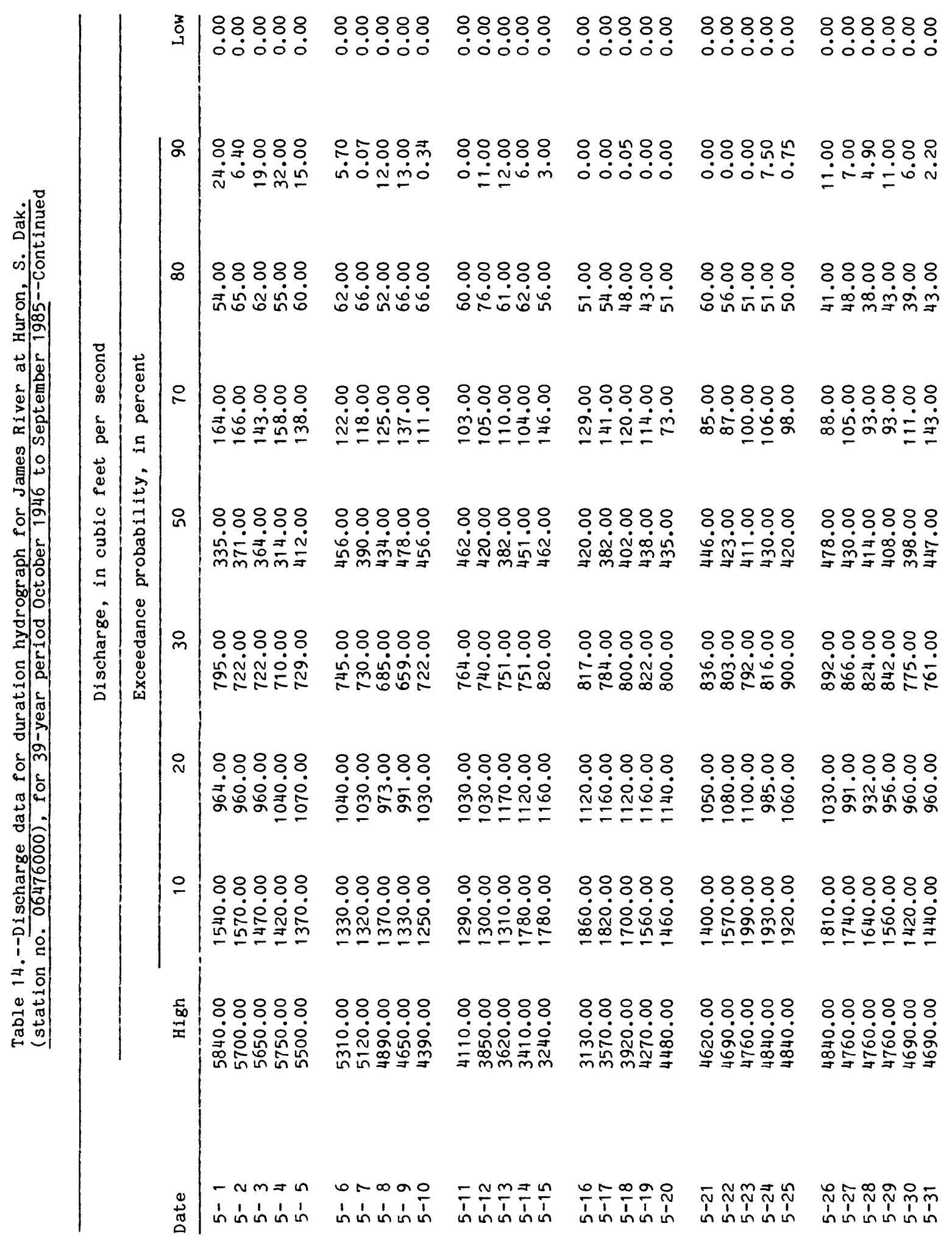




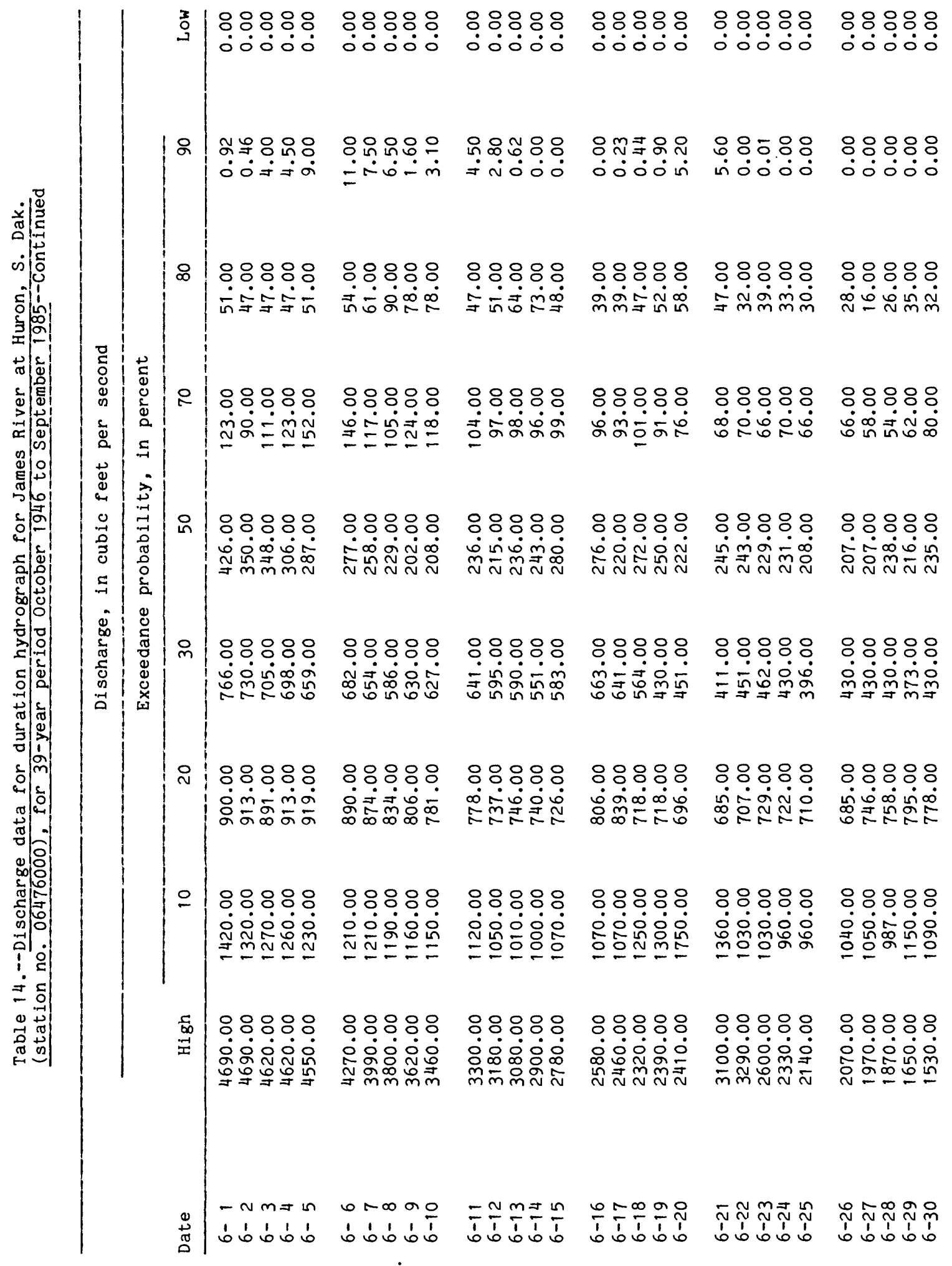




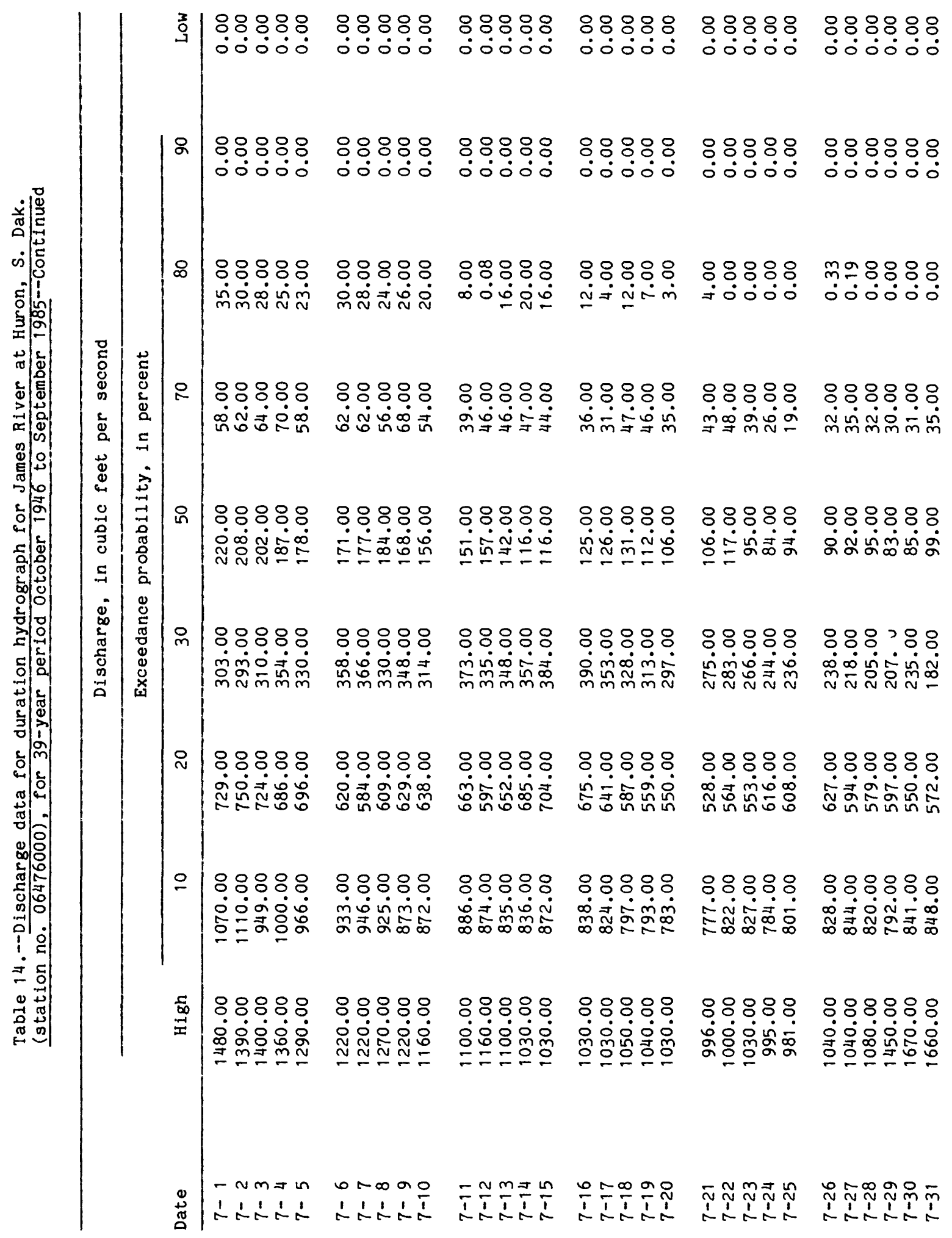




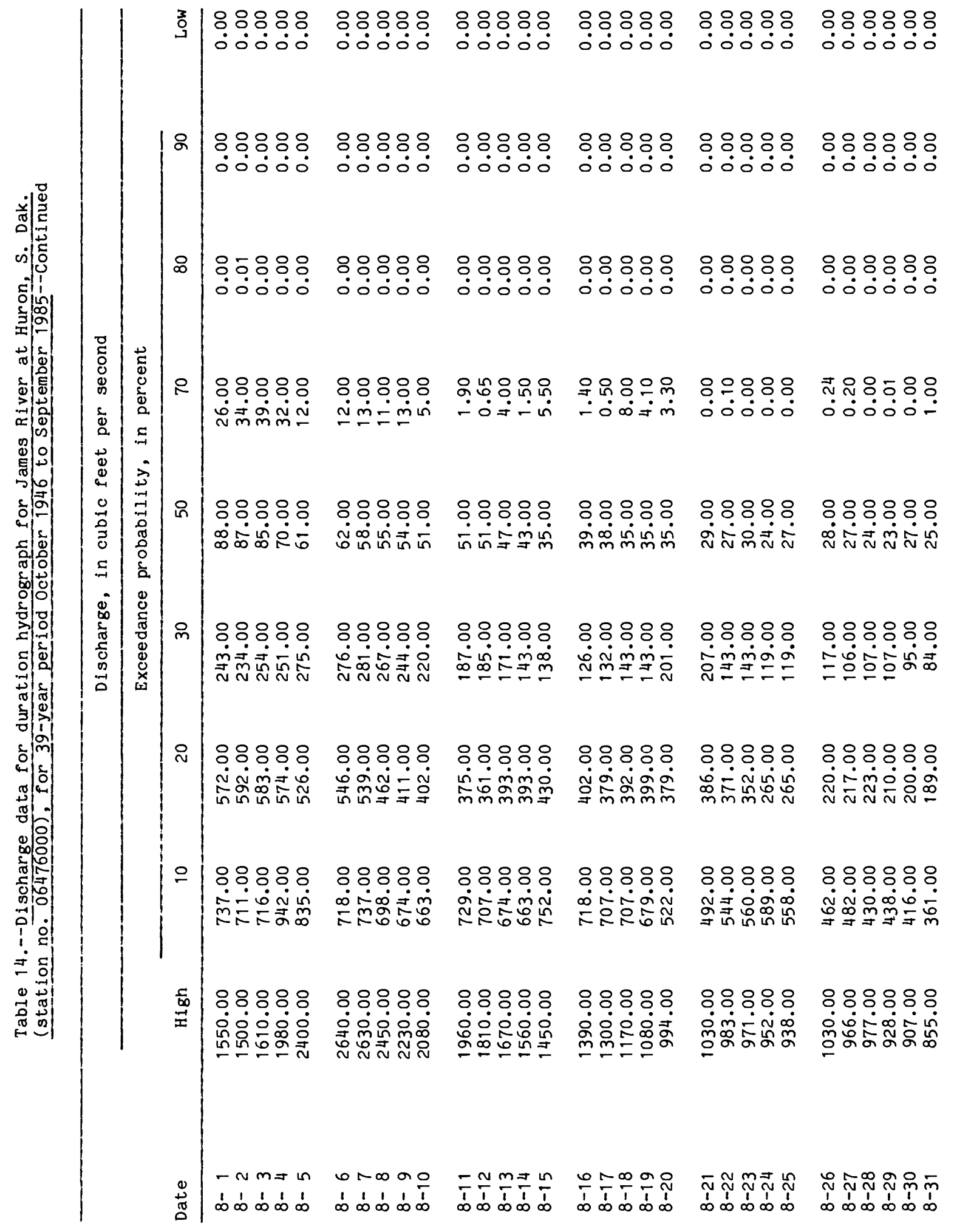




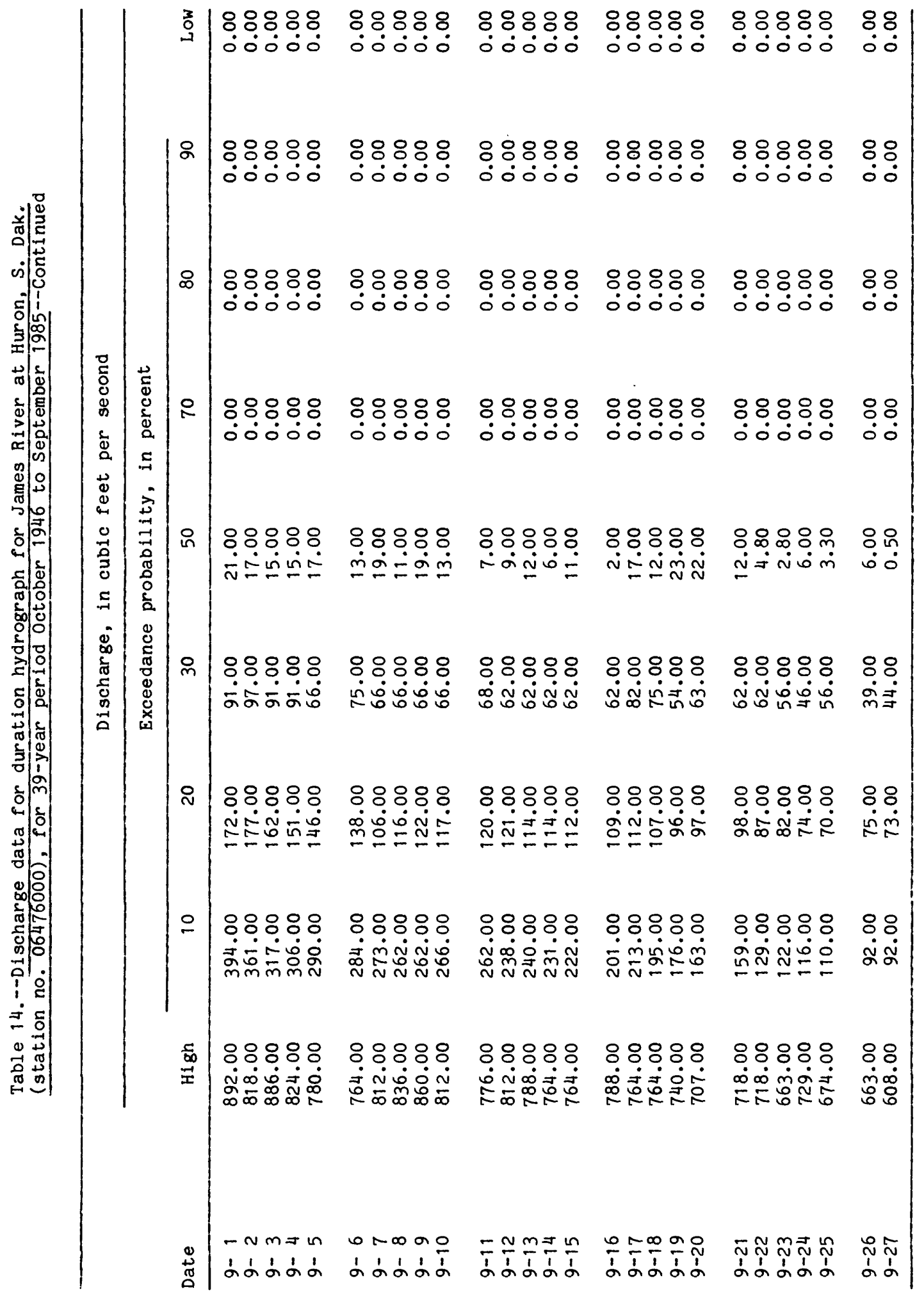




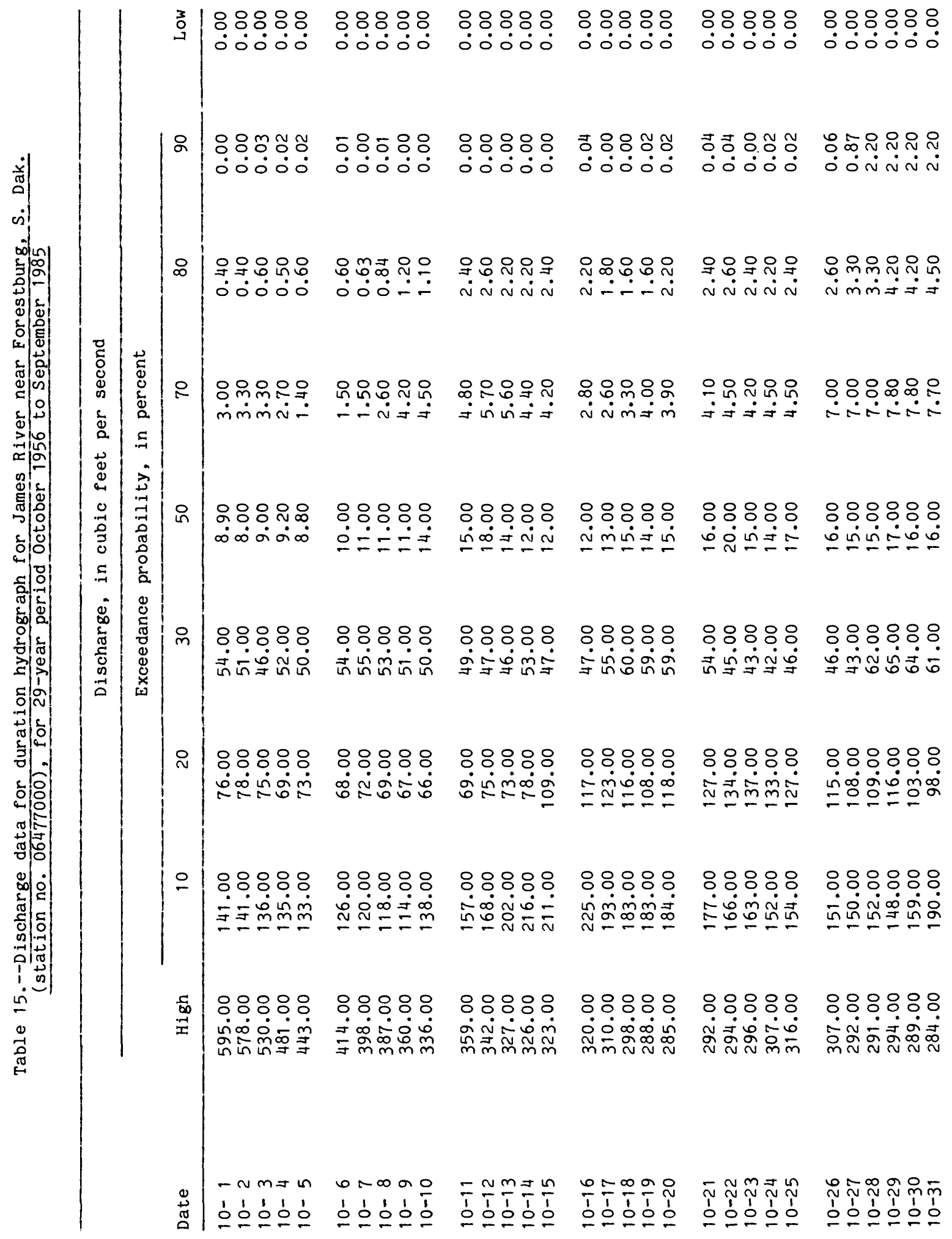




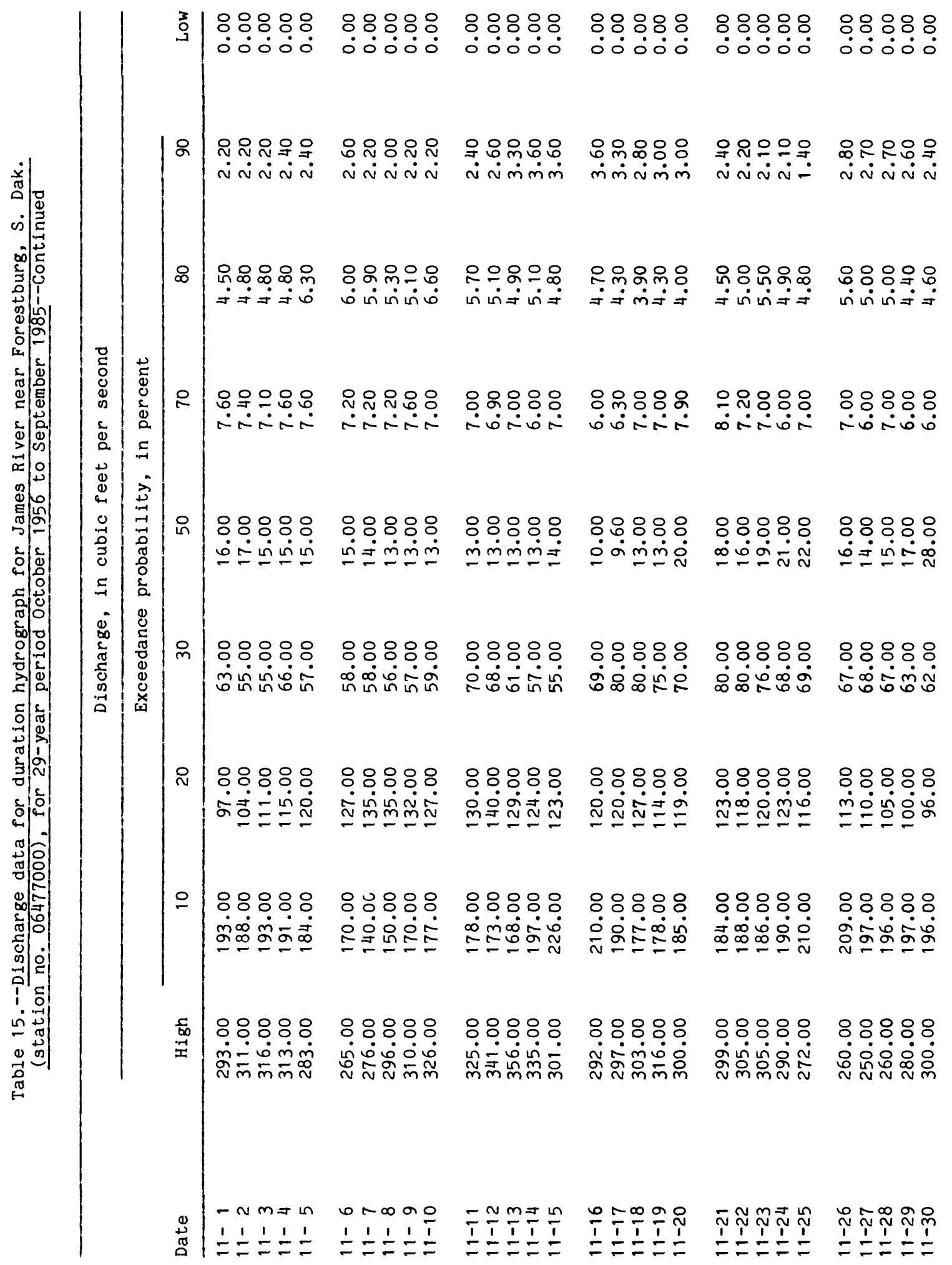




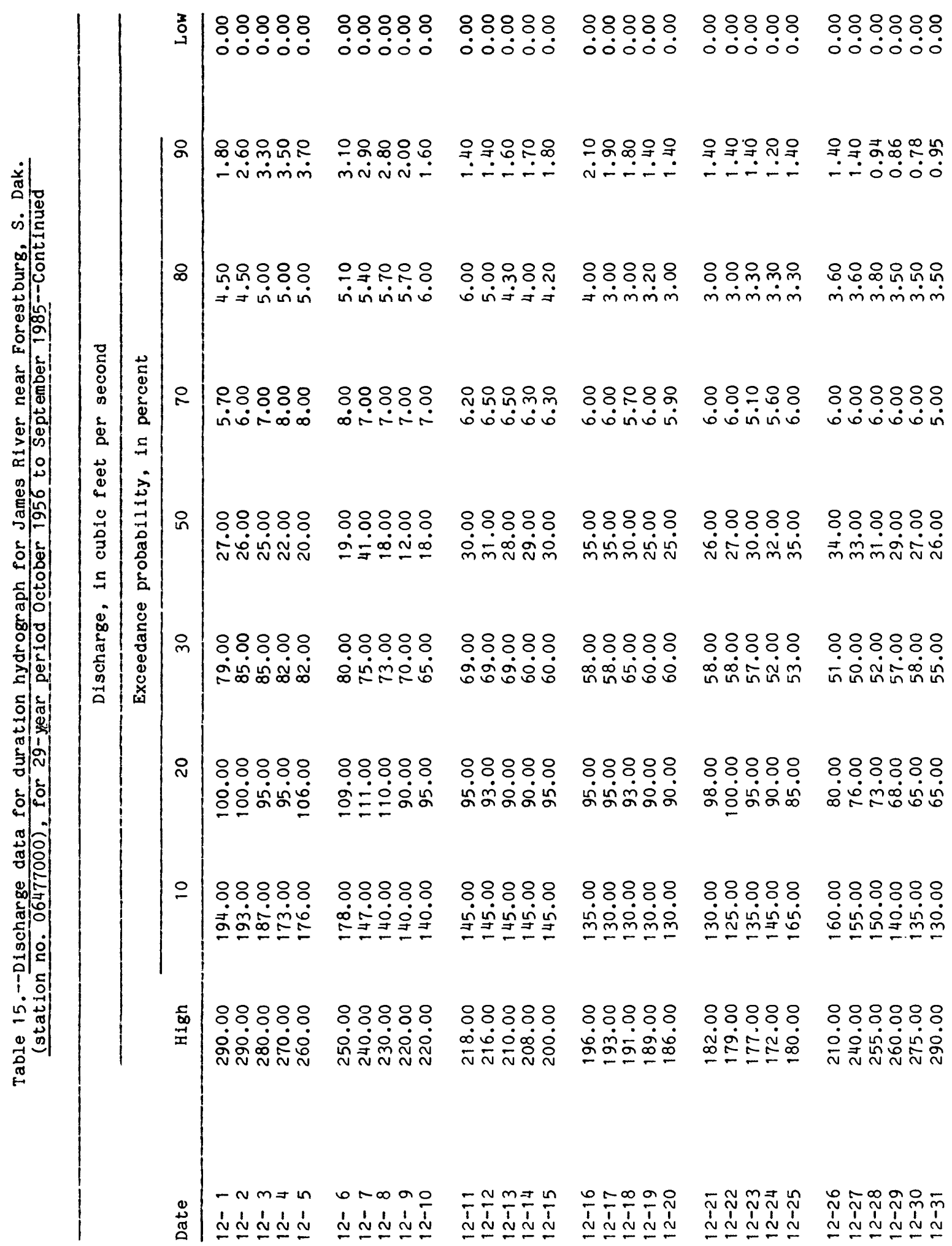




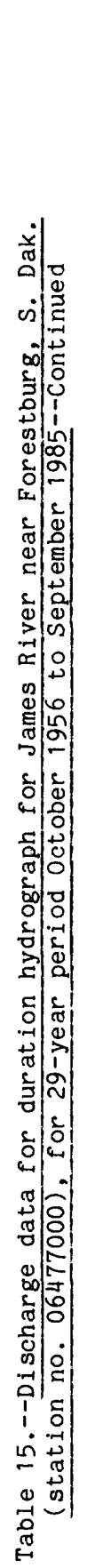

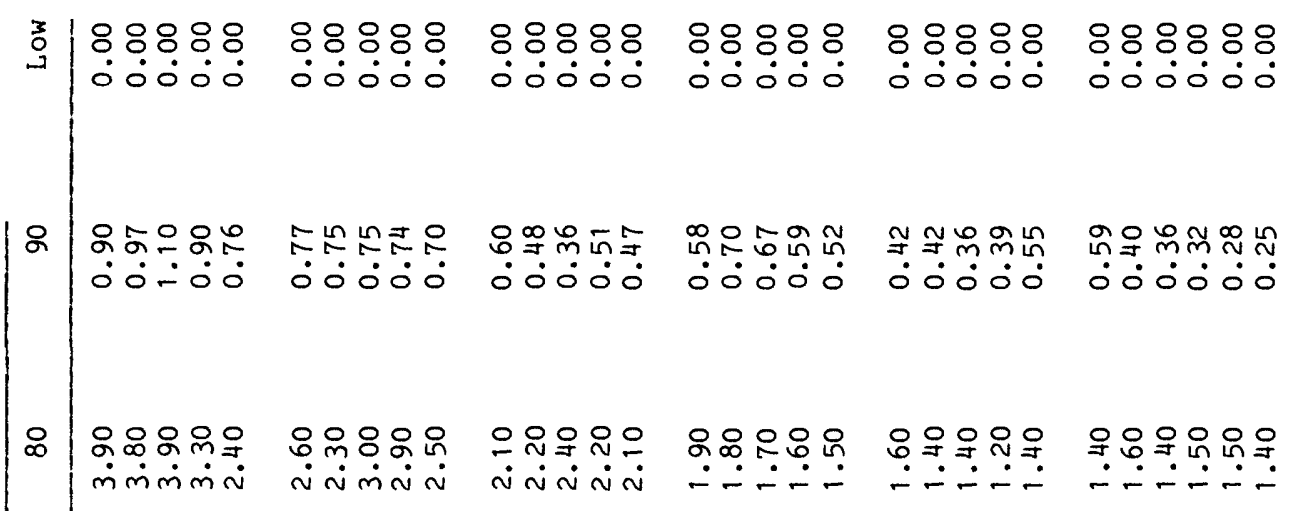

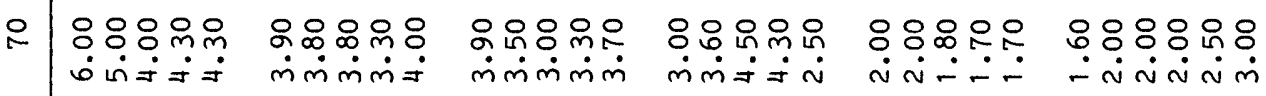

in 루ำi $8:$

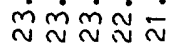

:8:8: 요용 ৪:৪৪:

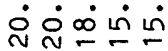

:8:8:

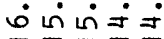

৪8:88: $\dot{n \dot{m}} \dot{m} \dot{m} \dot{m}$

ৎ 宇守守宁

:ஃ:०० $8: \circ: \circ$

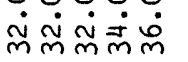

요웅

৪৪:৪৪: ம்ம்ற்ற் ஸ் $\dot{m} \dot{m} \dot{m} \dot{m} \dot{m}$

৪৪৪৪: ৪৪৪৪: த்혀: ப்형

৪:8:

88088

৪8:8:

8:88:8

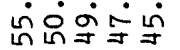

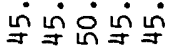

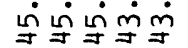

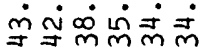

웅ㅇㅇ ํㅔ은 $8: 80 \%$ 우웅 80808 ปี่ ळ.

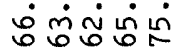

$8: 0 \div 8 \div$

묭ㅇ

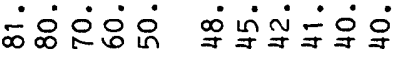

88888

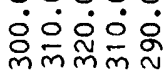

$8: 8: 8$

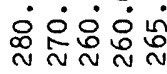

\section{৪৪৪:}

ن형요

$8: 88:$ 본ํํㅇㅇㅇ

৪৪:০

$\sin 10080$ ஆ

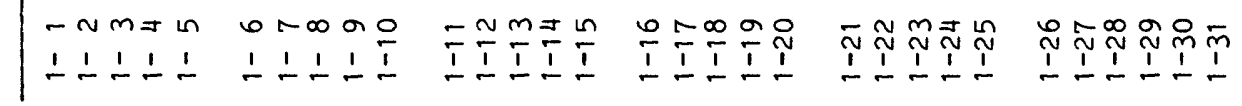




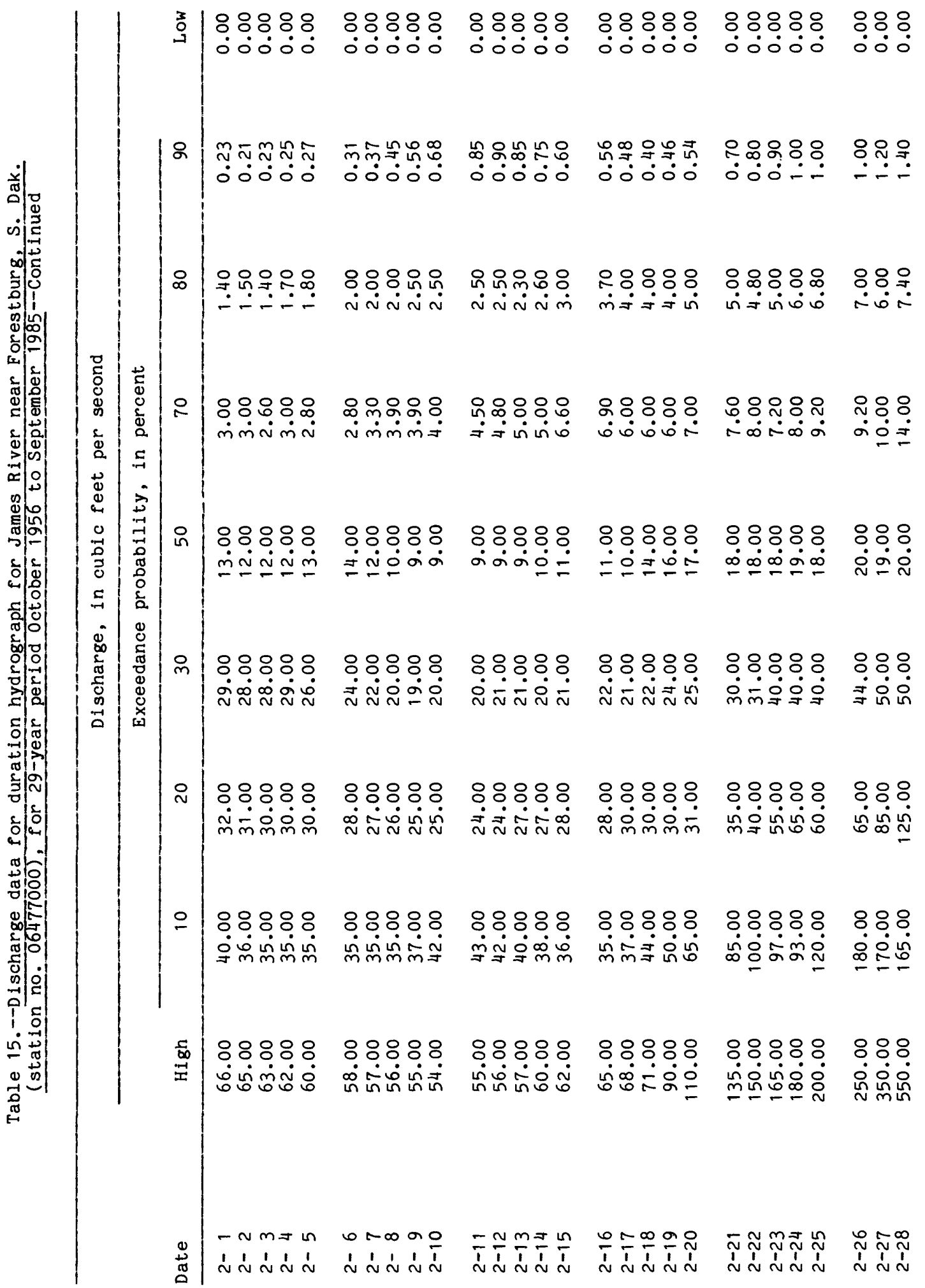




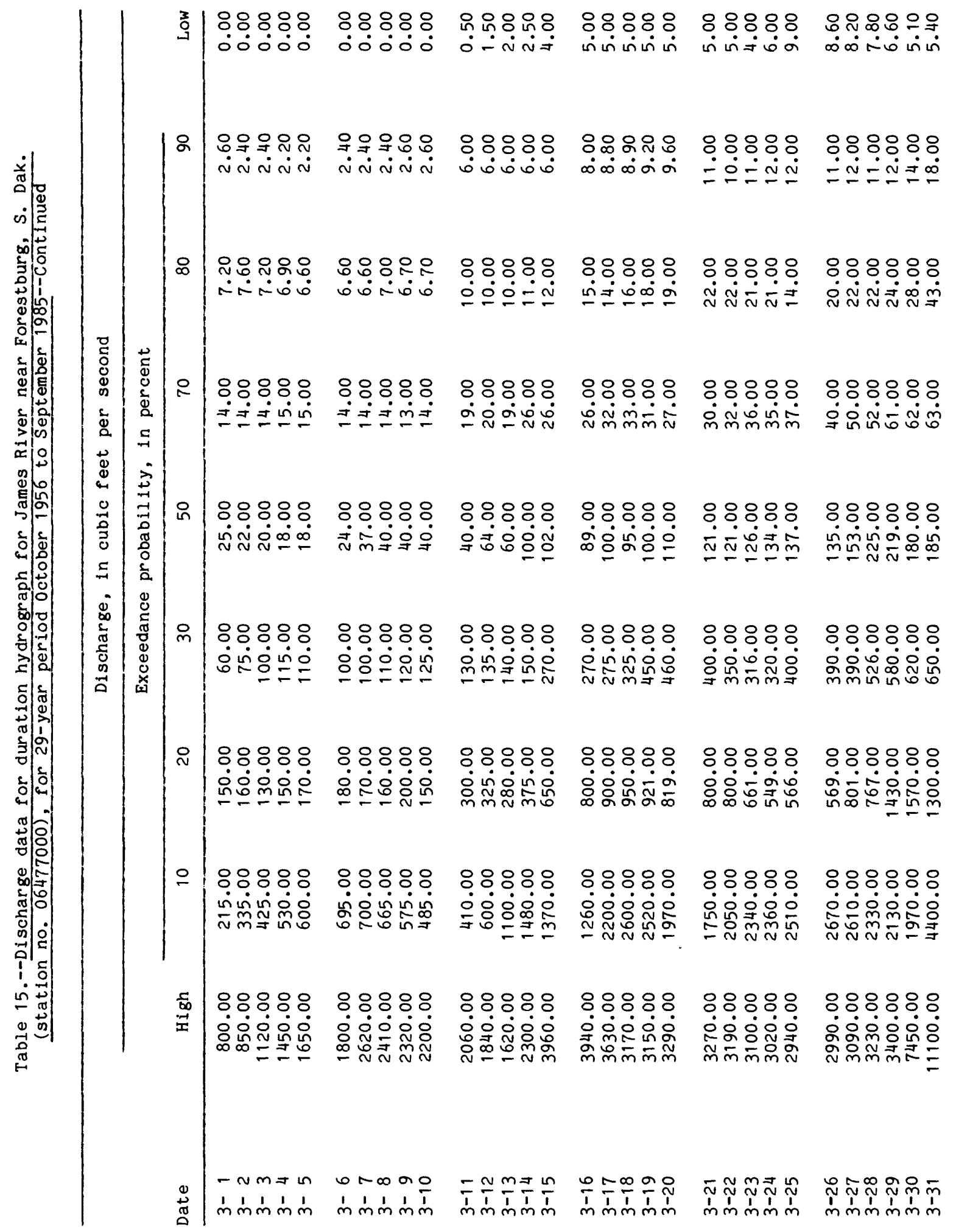




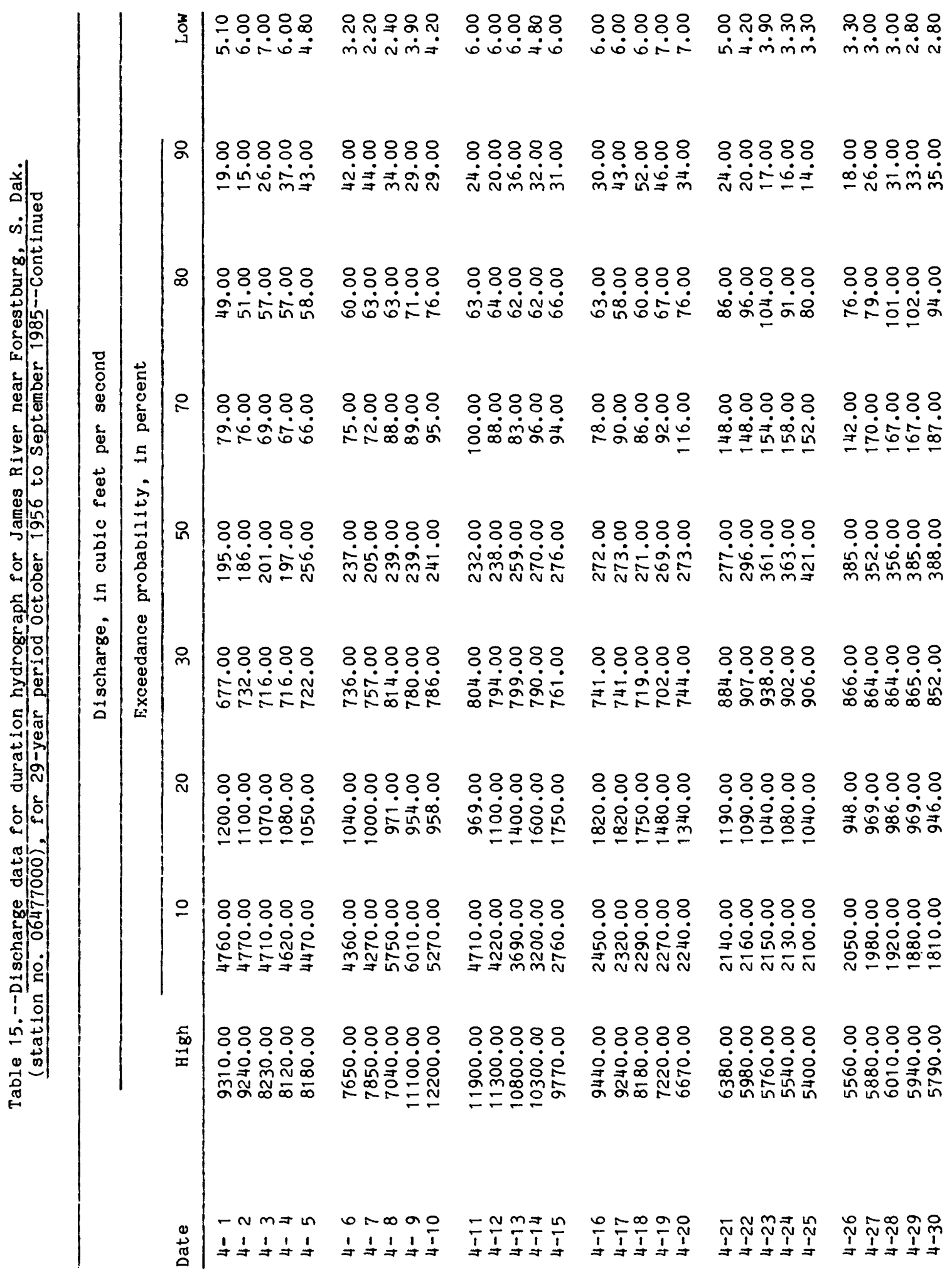




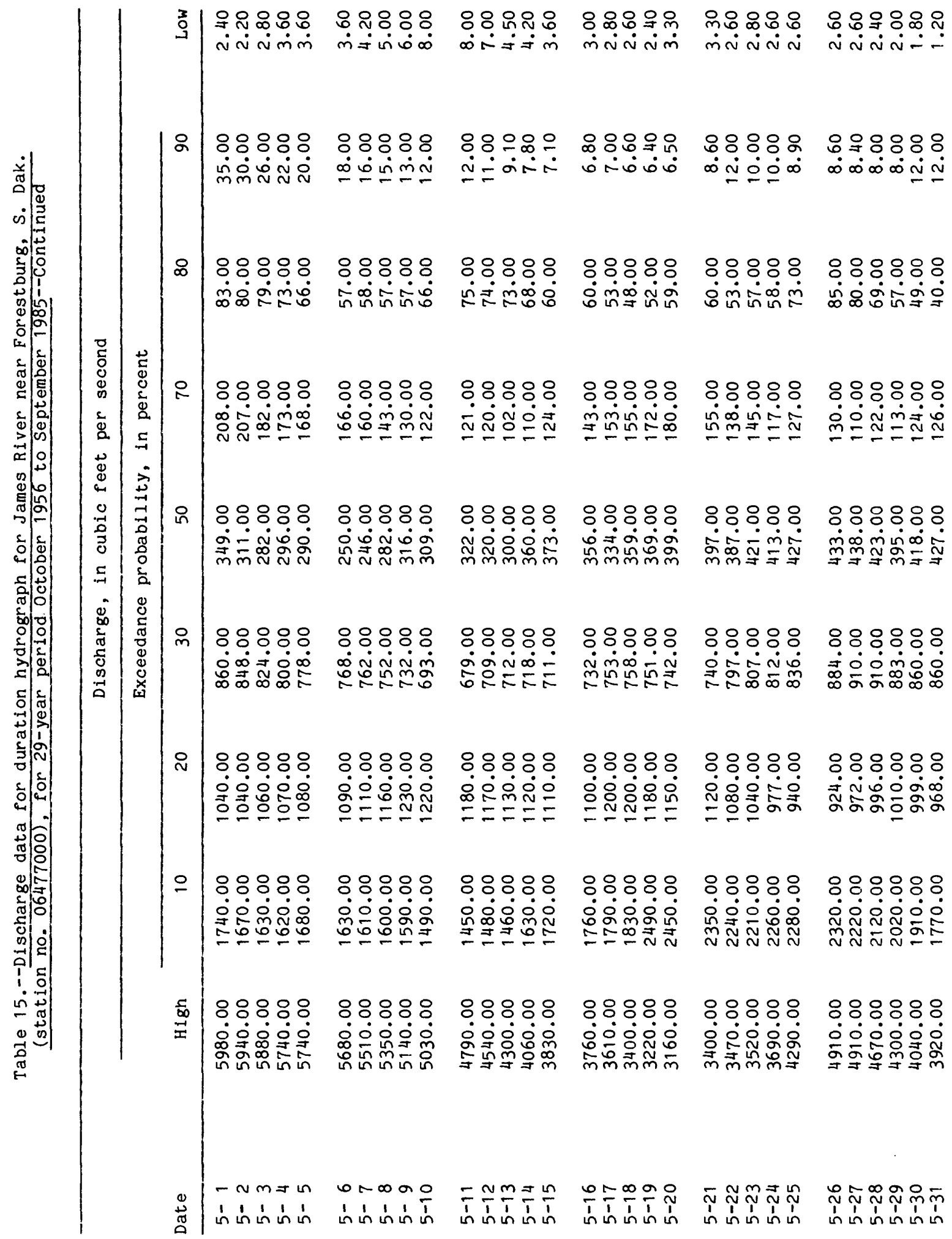




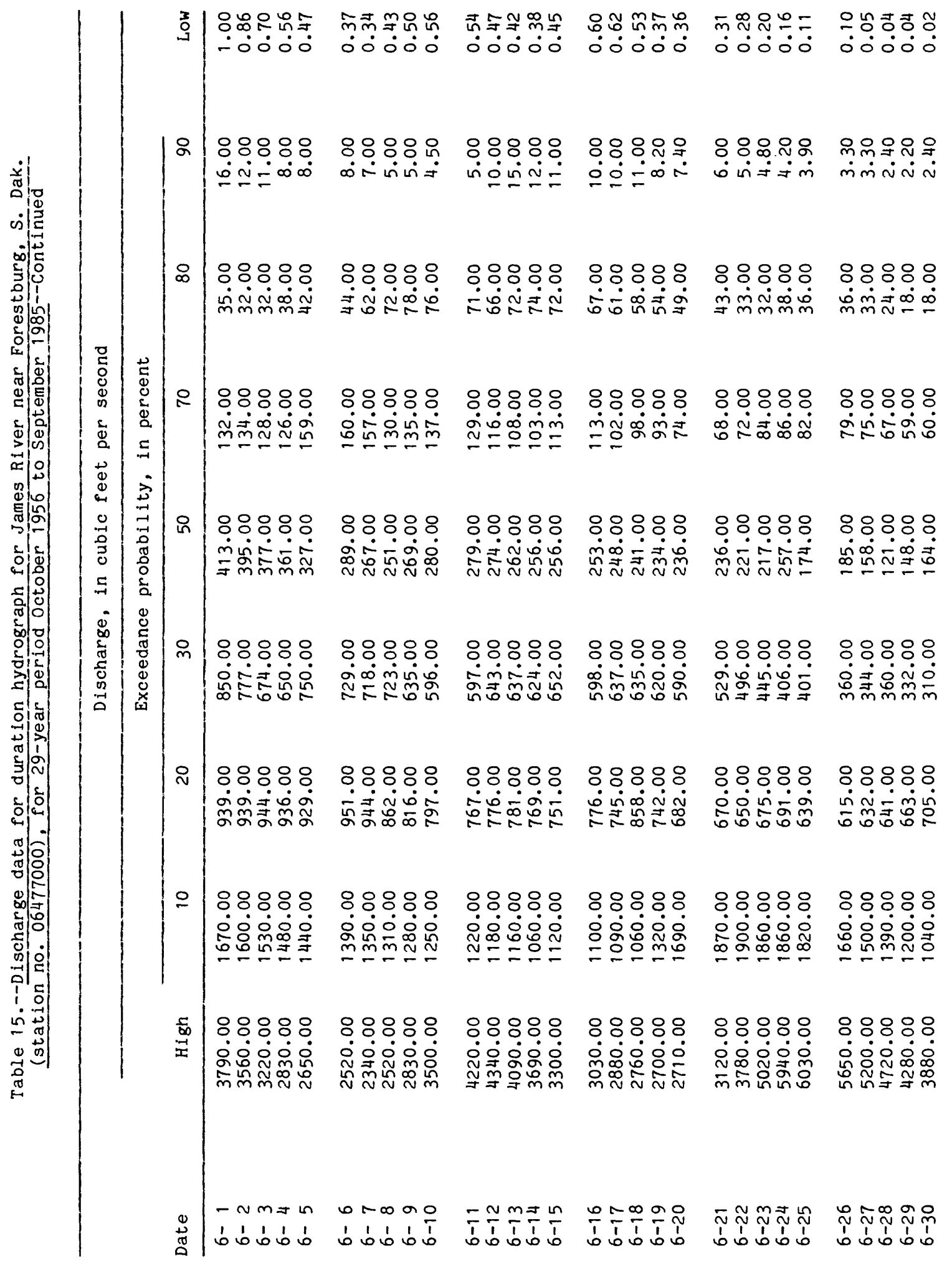




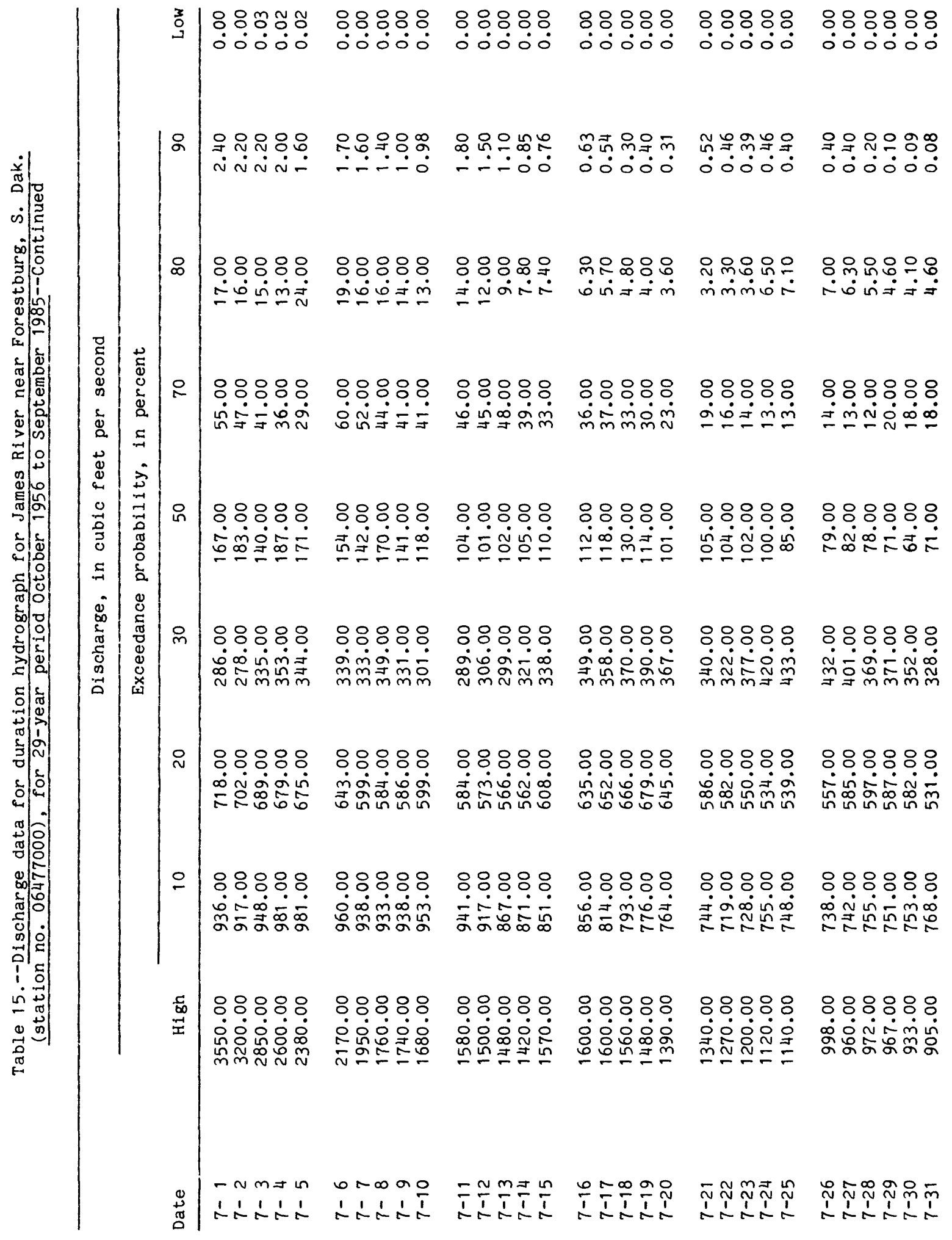




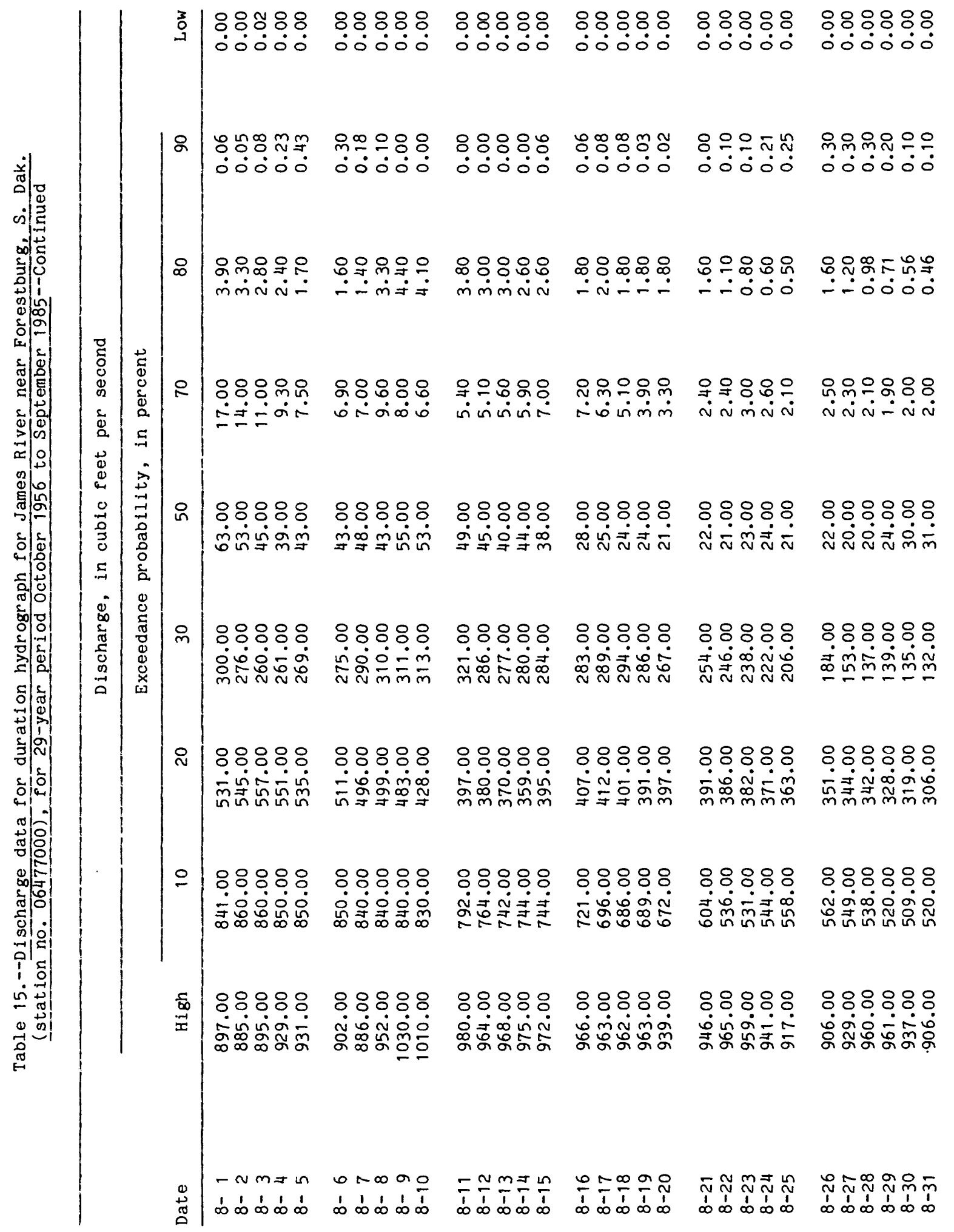




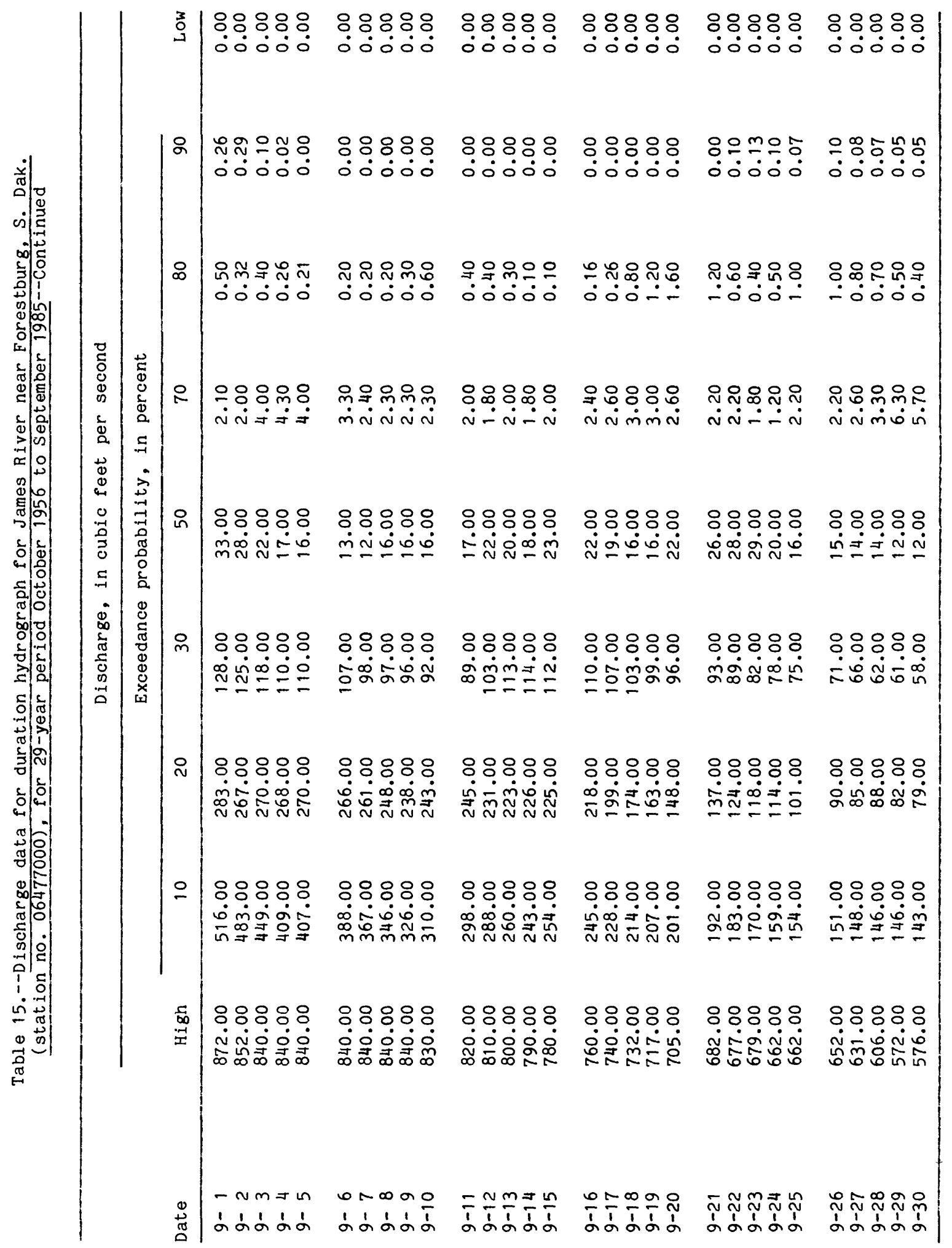




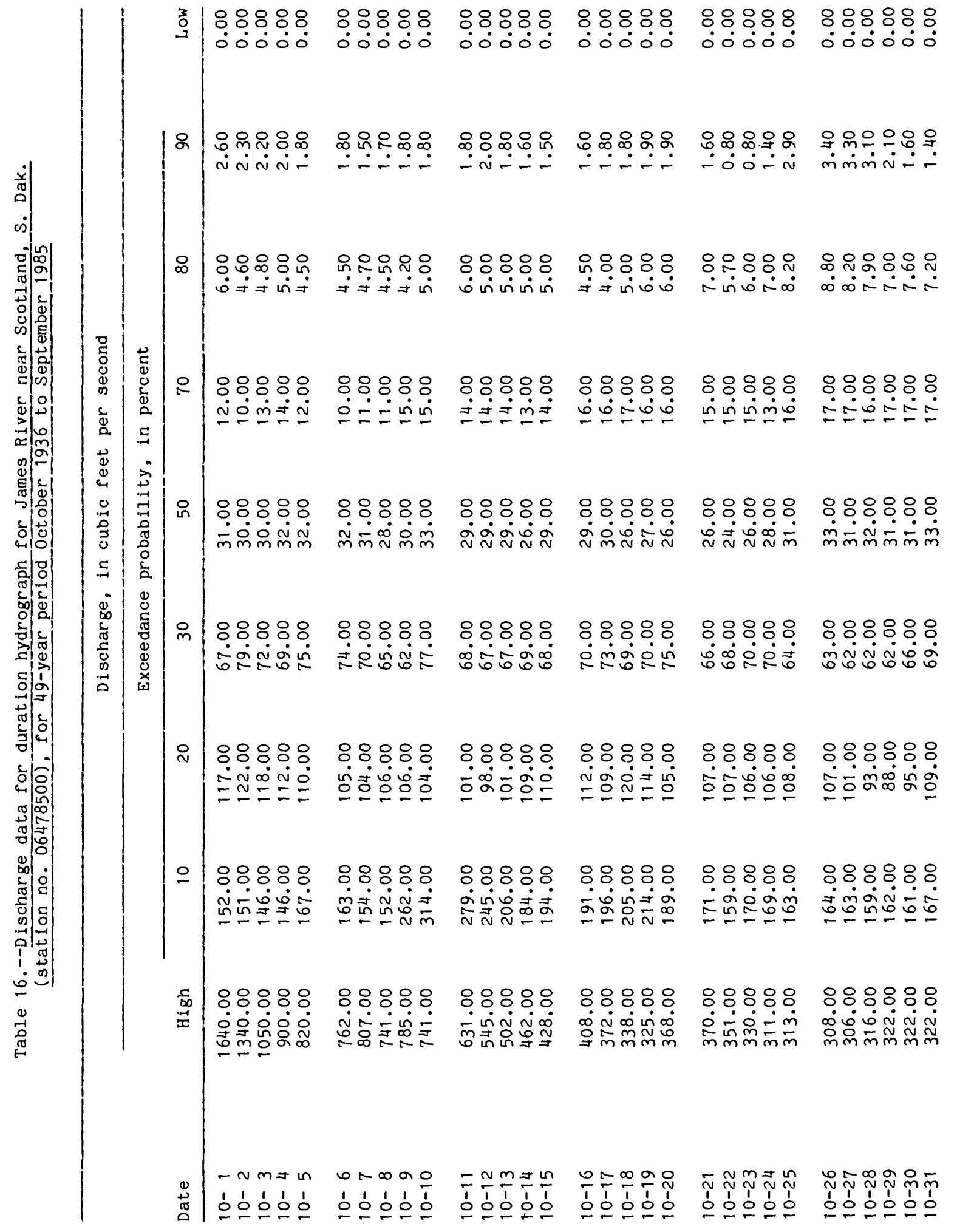




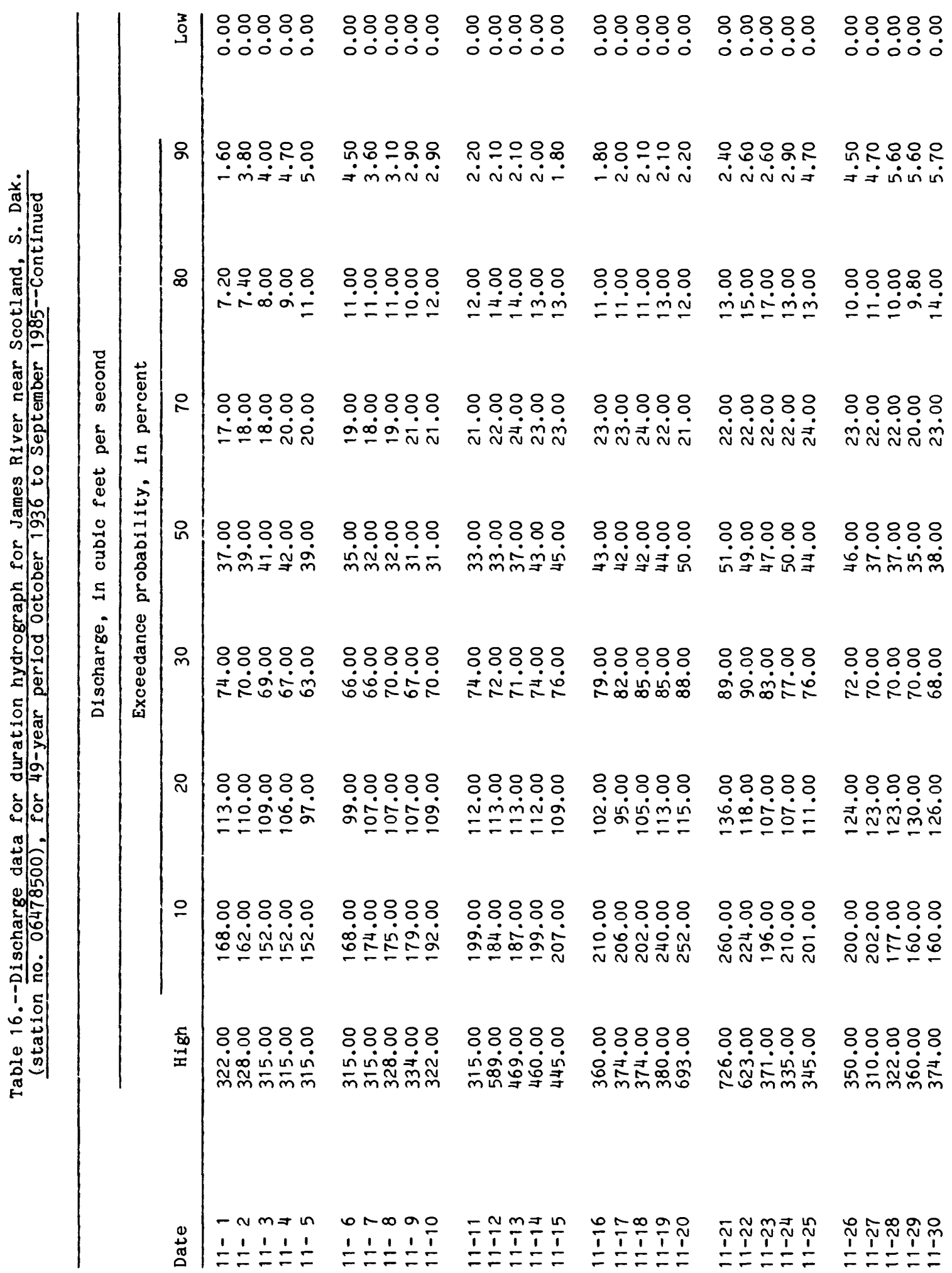


ஜำ:8:

$888: 8$

웅ㅇㅇㅇㅛ 웅윰융

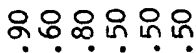

8

영유융ㅇㅇㅇㅇㅇ

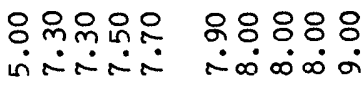

용ㅇㅇ 양유요용

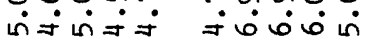

$\infty \dot{\infty} \dot{\infty} \dot{0}$

$\dot{0} \dot{0} \dot{0} \sigma^{\circ}$

$\infty$

ஃ:०:

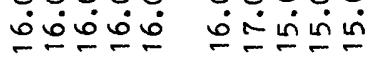

?

৪8:88 :88:8

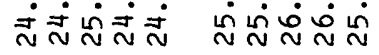

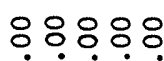

๓่ํํำ่

88808

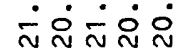

৪:৪:

i்ं0.

$8: 8: 8$

$\dot{0} \dot{\dot{0}} \dot{0}$

৪:০৪:

ம்ம்ம்

$8: 88: 8$

ம்ํำஸ்

우웅

ต்ํํㅇํㅇ

:ํ:๐:

宛的的官

$8: 80: 0$

mंimmiñ

용ํํ

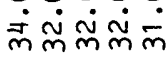

:ㅇํㅇ

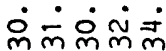

:৪::৪:

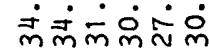

요

৪৪৪৪৪ ৪৪৪:৪

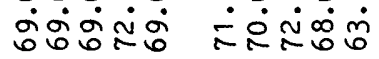

৪৪৪৪ঃ

ธิ்்َ่:

88888

ஸ่อั்்่่

$8: 8: 8$

ஸ் $\dot{0} \dot{0}$

৪৪:8:

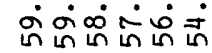

이

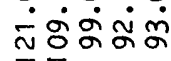

:88:

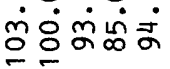

88.80

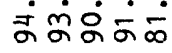

우웅

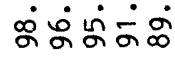

৪:웅

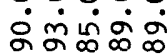

৪৪৪:৪ঃ

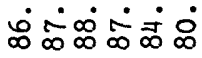

- 88088

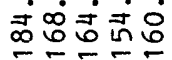

88888

ติ่ง்่ำ

88088

ஸ்

88888

这完宇

৪৪8:

ษ

808080

ㅇํำํํำ

৪৪:ㅇ

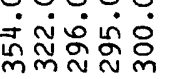

8:80: 요웅

जُ

80808

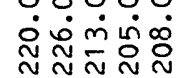

80808

(1)

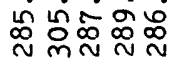
เก $\stackrel{n}{\sim} \underset{\sim}{n}$ 


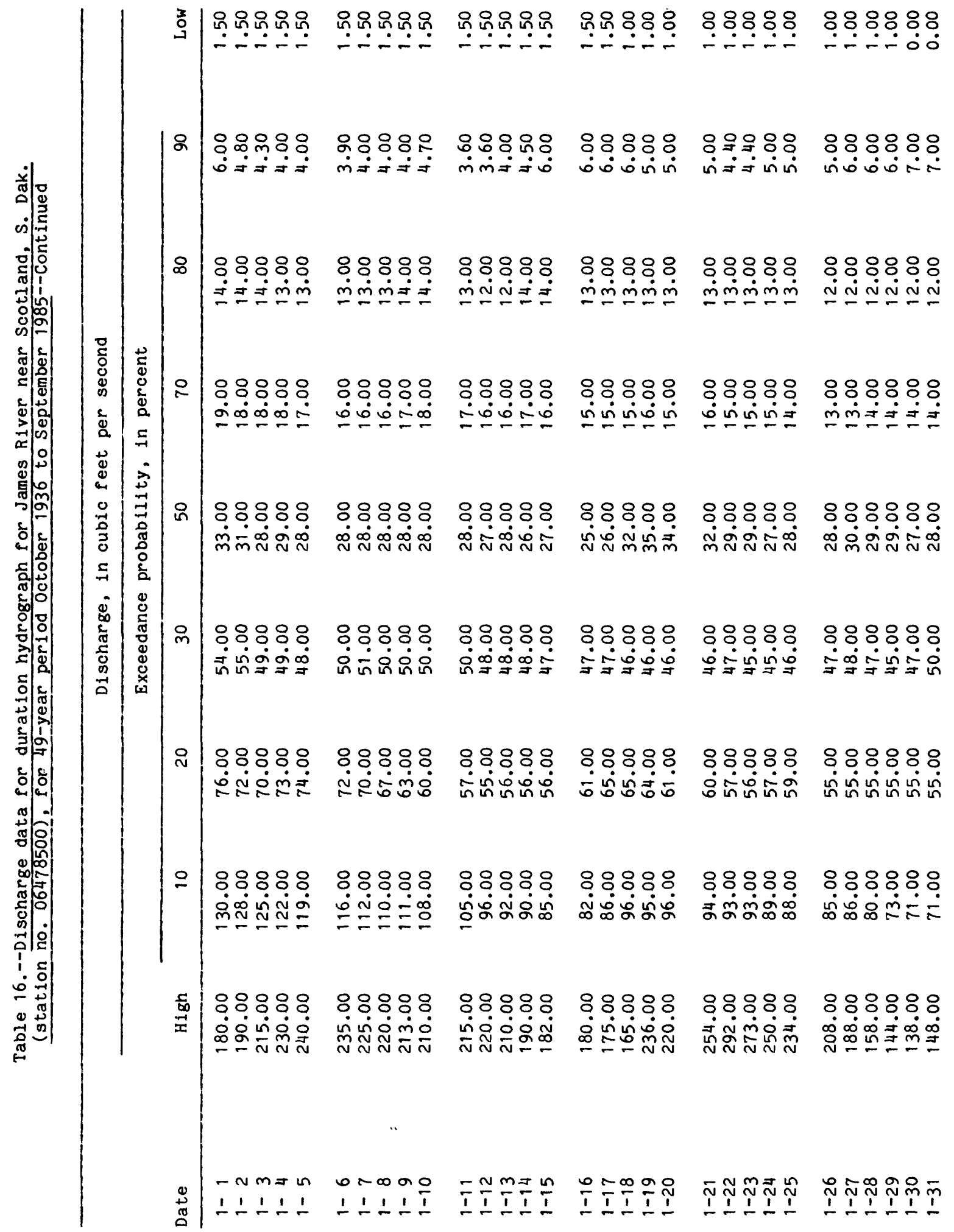




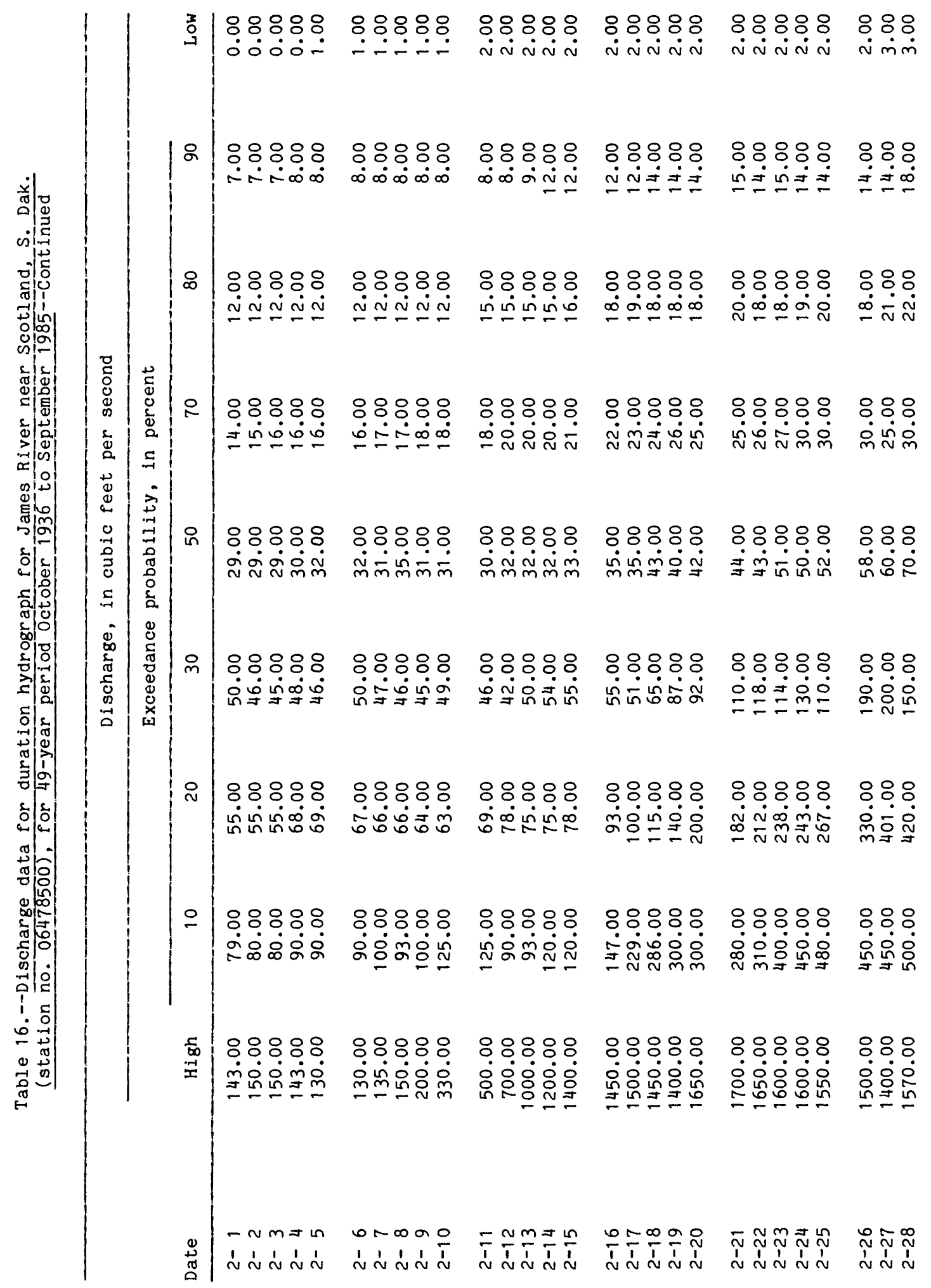




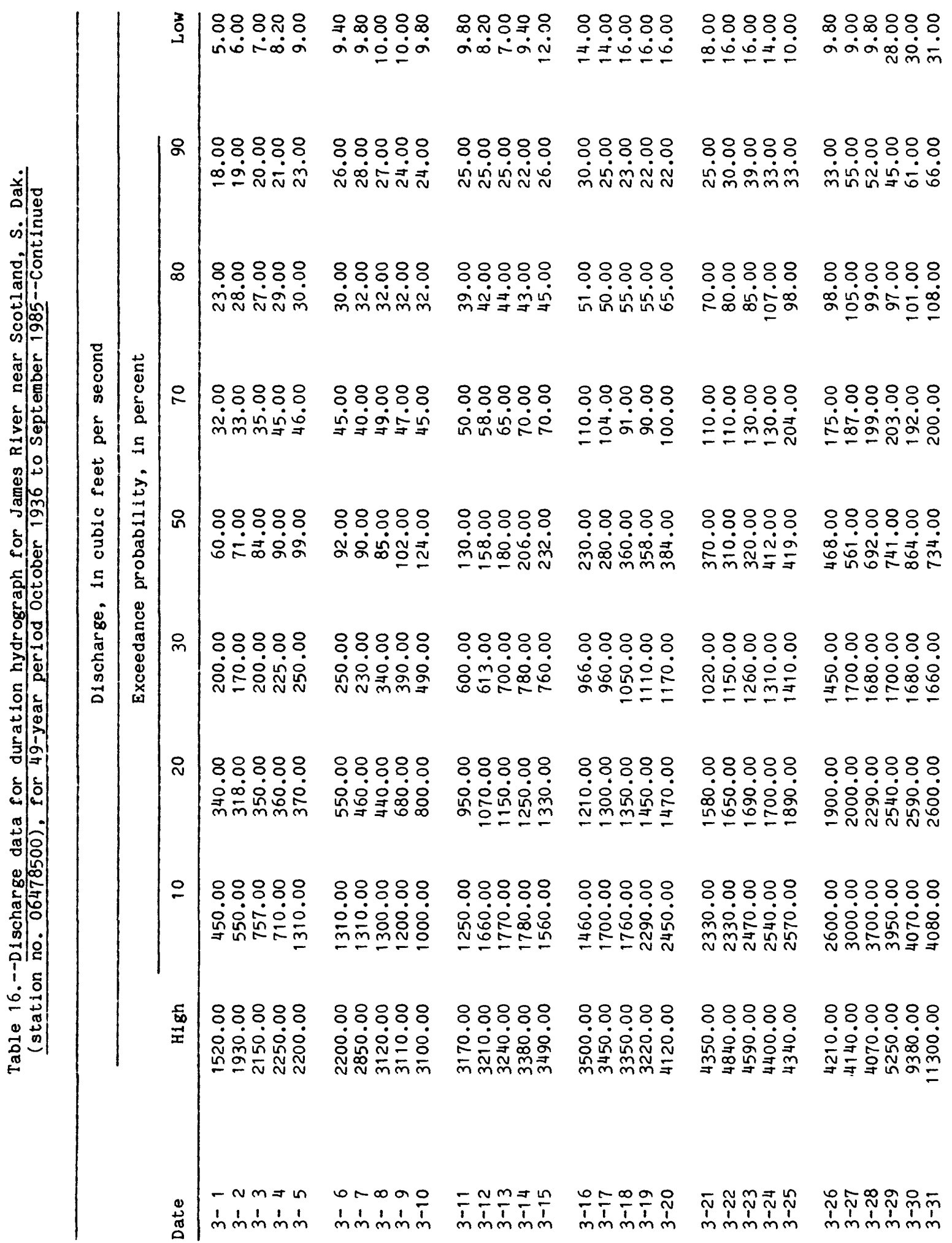




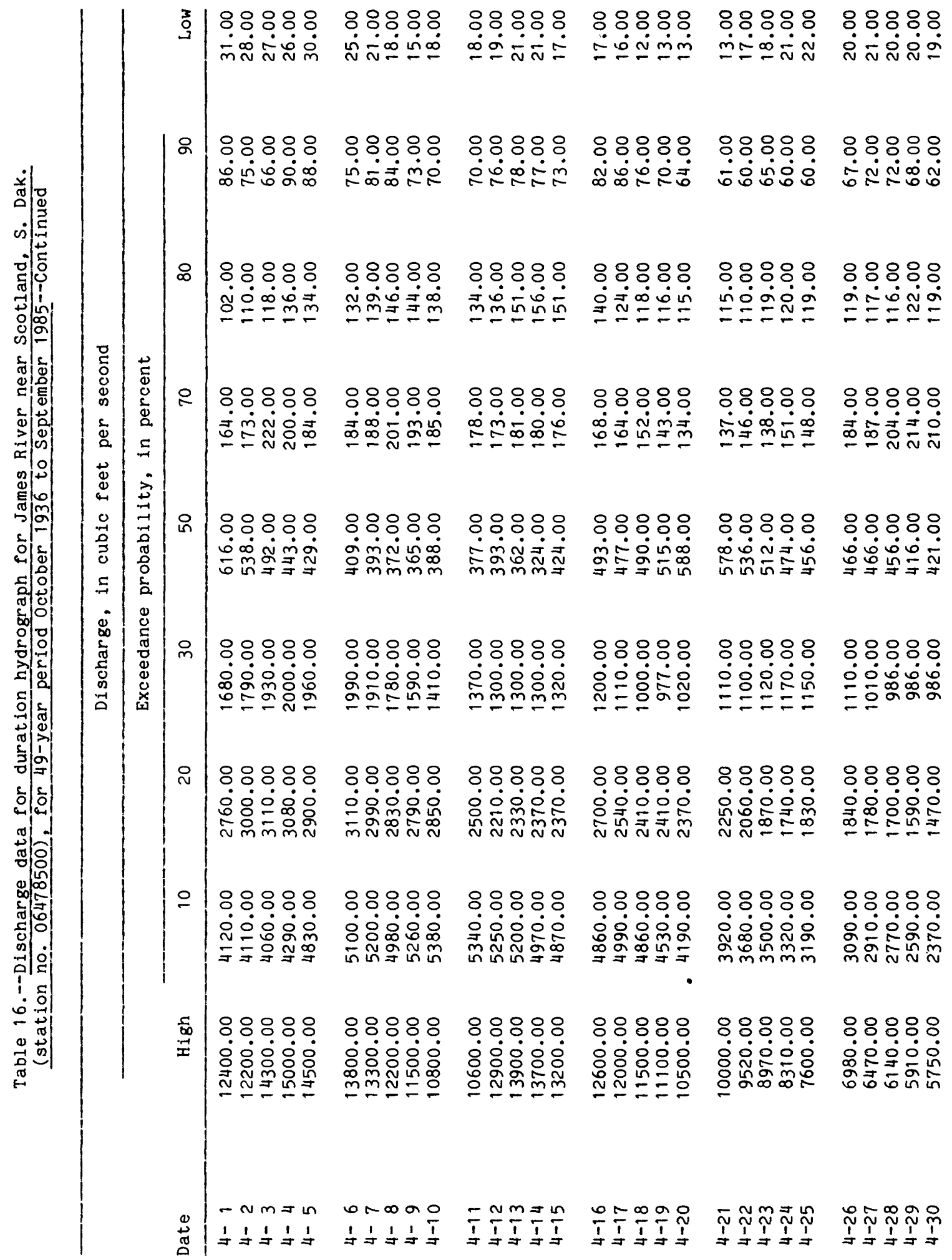




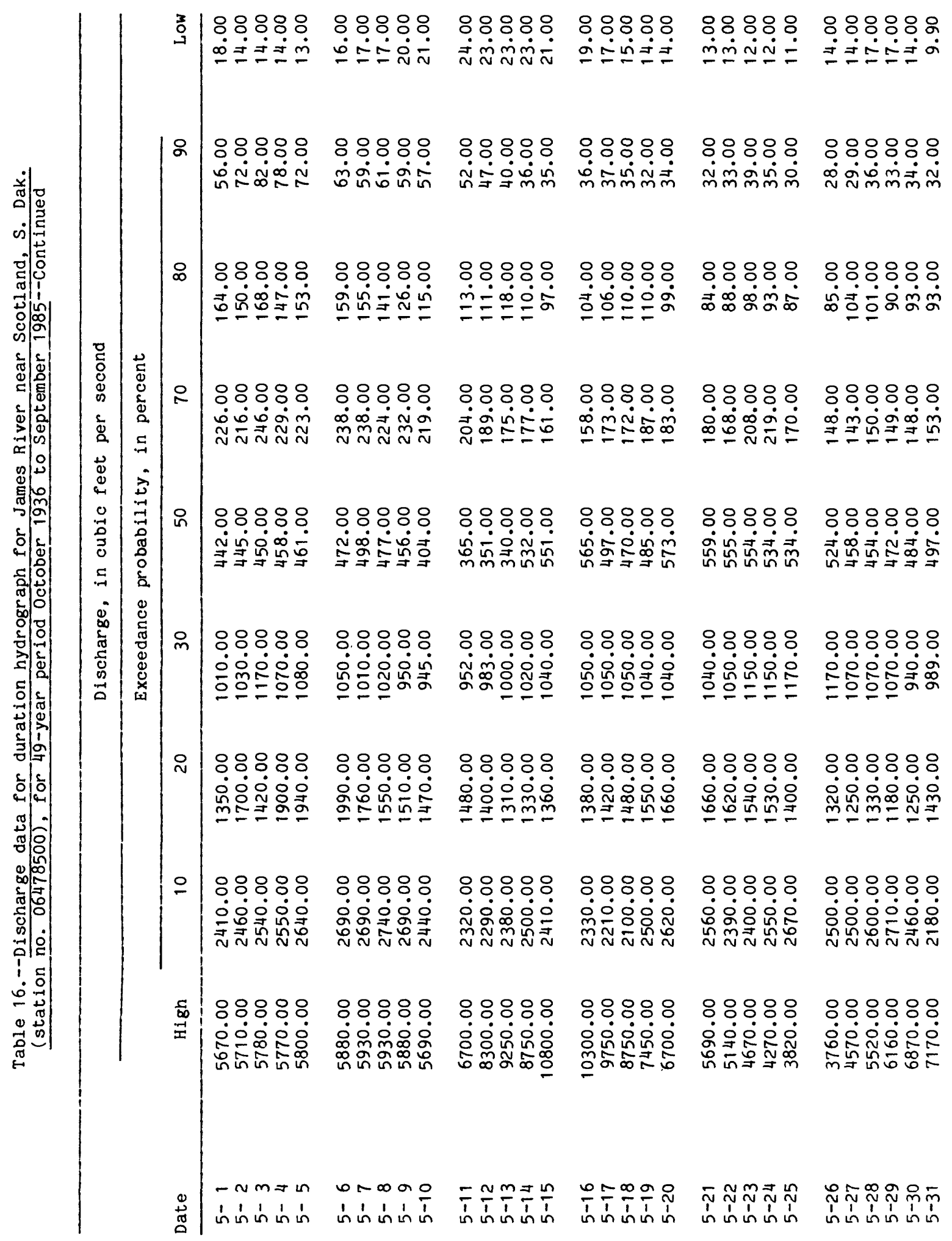




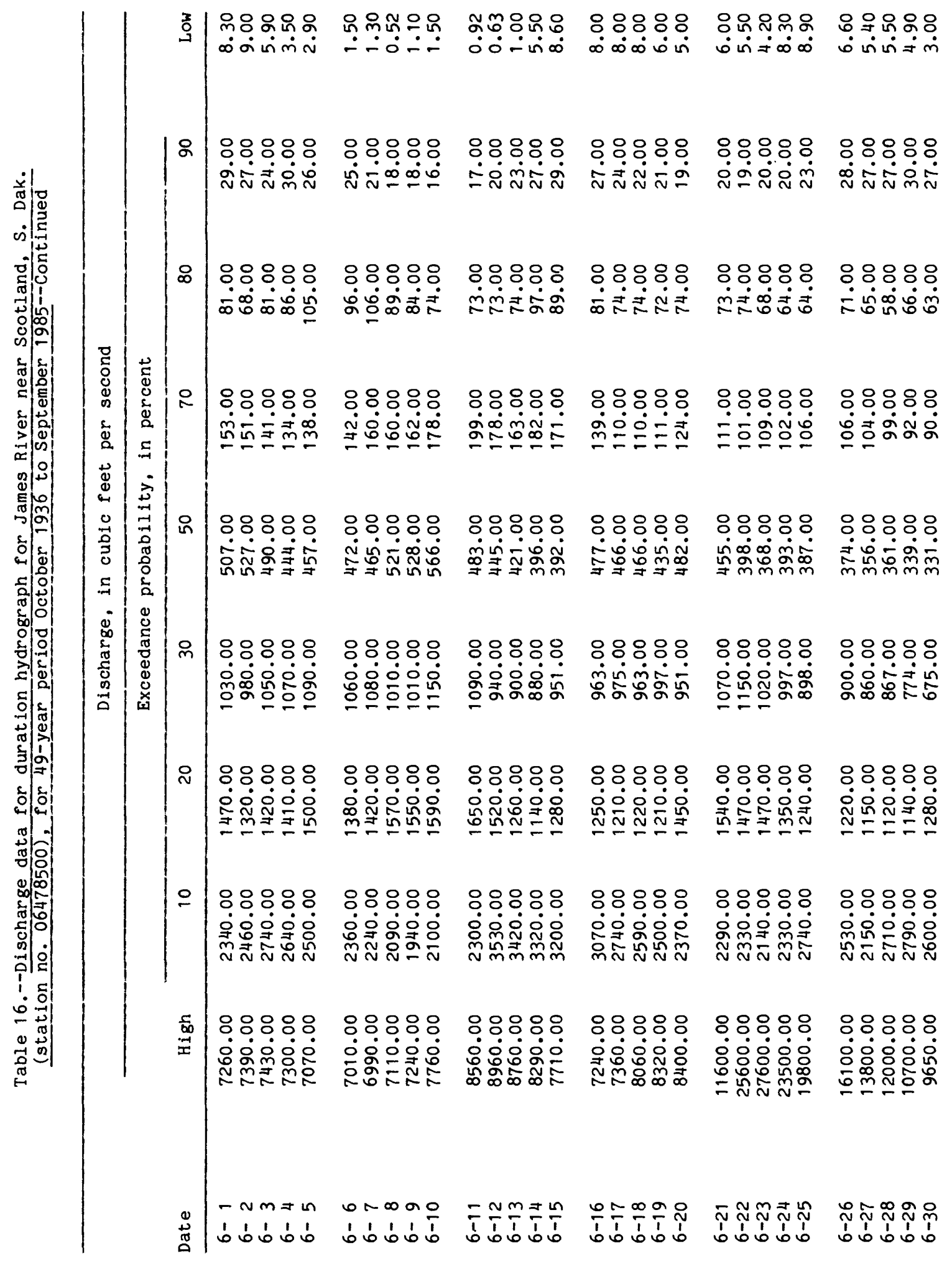




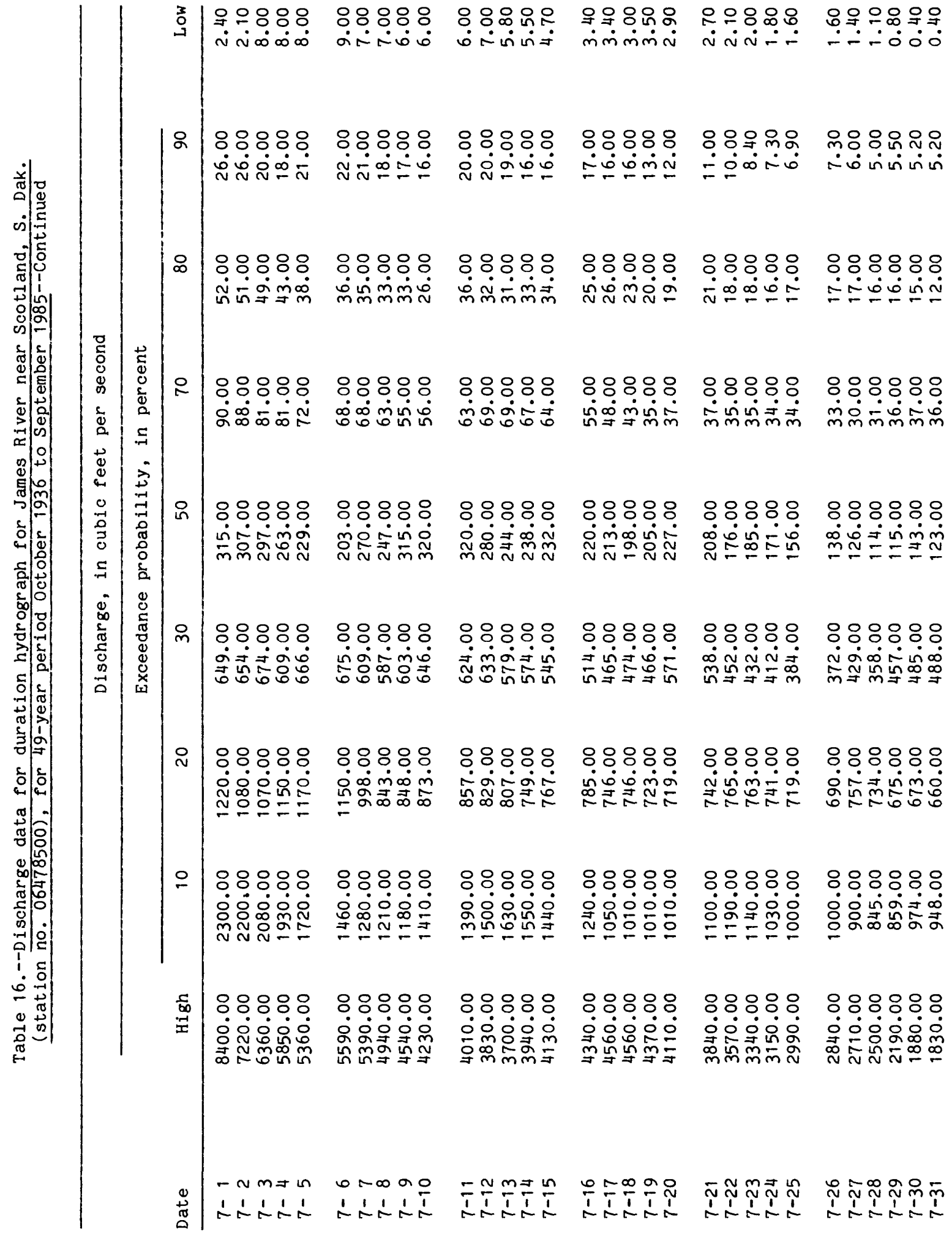




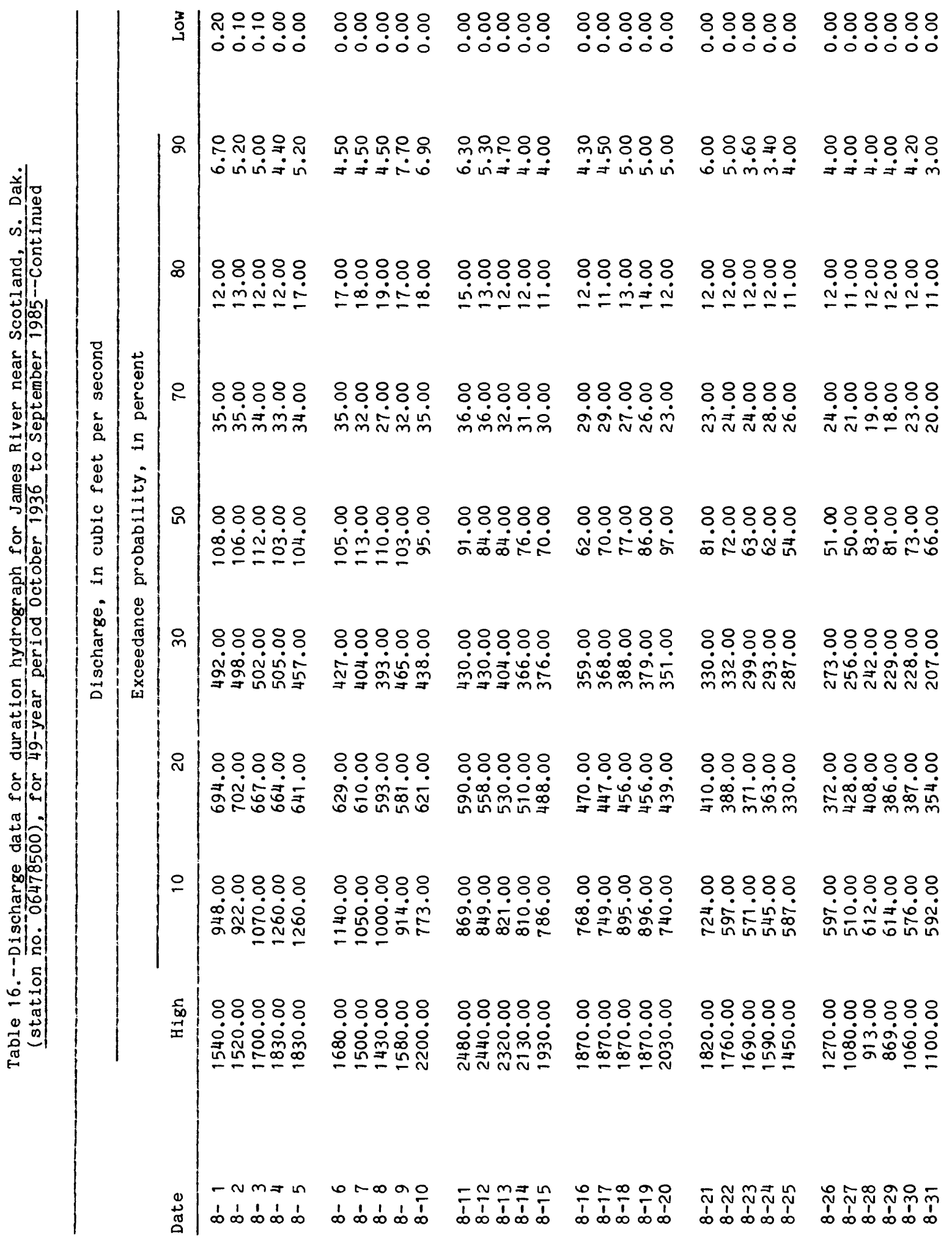




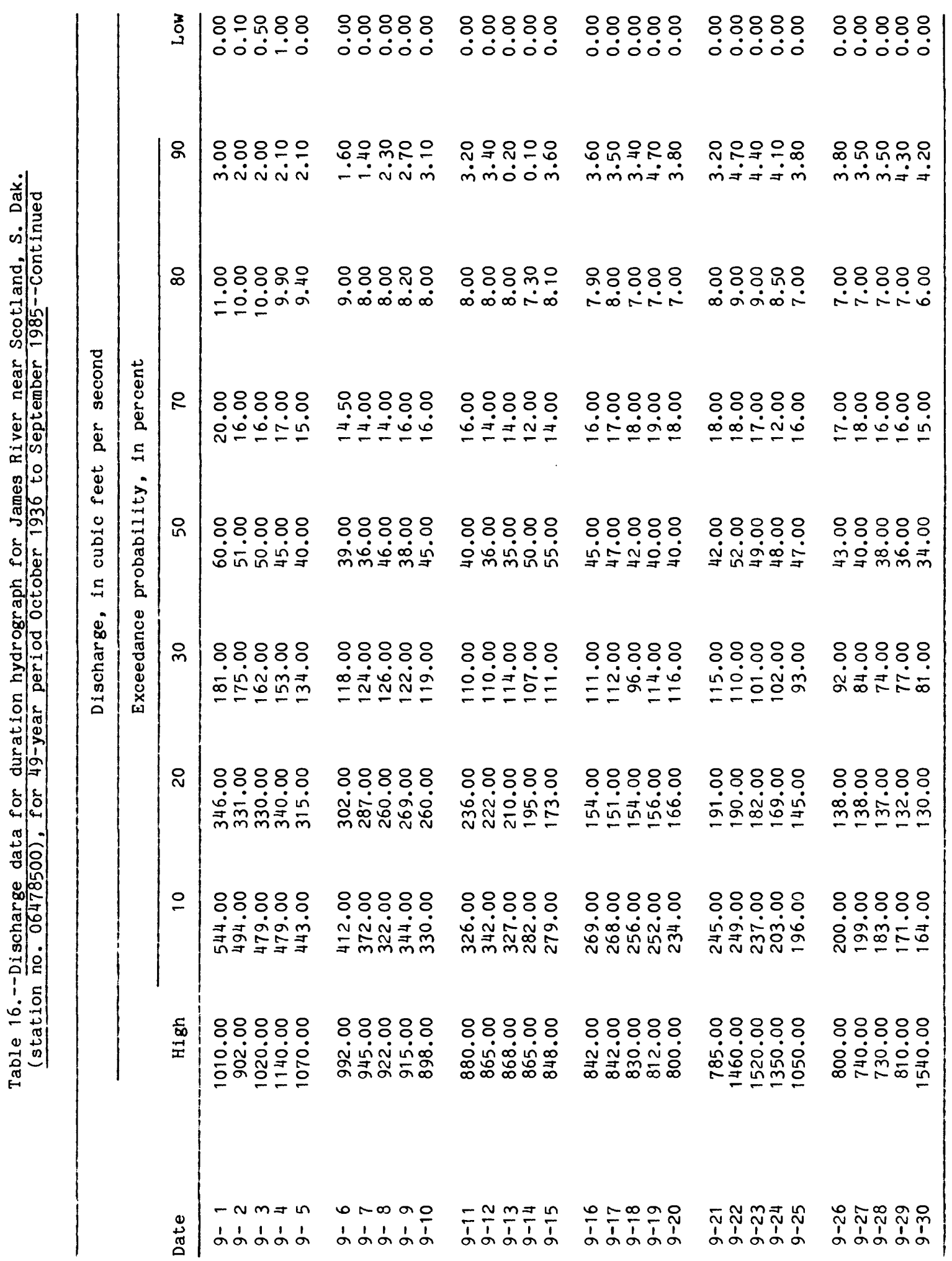

